UNIVERSIDADE DE SÃO PAULO

FACULDADE DE FILOSOFIA LETRAS E CIÊNCIAS HUMANAS

DEPARTAMENTO DE FILOSOFIA

PROGRAMA DE PÓS-GRADUAÇÃO EM FILOSOFIA

\title{
O Louvor do Excesso: Experiência, Soberania e Linguagem em Bataille
}

Luiz Augusto Contador Borges

Versão corrigida 


\title{
UNIVERSIDADE DE SÃO PAULO \\ FACULDADE DE FILOSOFIA LETRAS E CIÊNCIAS HUMANAS \\ DEPARTAMENTO DE FILOSOFIA \\ PROGRAMA DE PÓS-GRADUAÇÃO EM FILOSOFIA
}

\section{O Louvor do Excesso: Experiência, Soberania e Linguagem em Bataille}

\section{Luiz Augusto Contador Borges}

\begin{abstract}
Tese de doutorado: versão corrigida apresentada ao Programa de Pós-Graduação em Filosofia do Departamento de Filosofia da Faculdade de Filosofia, Letras e Ciências Humanas da Universidade de São Paulo, para obtenção do título de Doutor em Filosofia, de acordo com o orientador: Prof Dr. Leon Kossovitch
\end{abstract}

São Paulo

2012 
É expressamente proibida a comercialização deste documento, tanto na sua forma impressa como eletrônica. Sua reprodução total ou parcial é permitida exclusivamente para fins acadêmicos e científicos, desde que na reprodução figure a identificação do autor, título, instituição e ano da tese. 
A Leon Kossovitch, pelo olhar firme e vigilante, pela escuta atenta, pelo aprendizado com afeto, dedico este trabalho. 
AGRADECIMENTOS

Aos parentes e amigos de todas as horas:

Maria José Monte, Dominique Fingermann, Eliane Robert Moraes, Valter José Maria, José Roberto Borges ,Claudia Helena Borges, Eunice Vieira e Adelino Vieira, ao gato Luigi, e aos saudosos tios Stylianos Vaitsakis, Eunice Borges e Corina Borges, e a minha querida Mariana Vieira, que de algum modo contribuíram para que este trabalho viesse a lume. 
"É favor das estrelas nos convidar a falar, nos mostrar que não estamos a sós, que a aurora tem um teto e meu fogo as tuas mãos."

René Char 
RESUMO:

Em linhas gerais o projeto consiste numa abordagem do pensamento do escritor francês Georges Bataille, no viés de sua crítica à razão ocidental, tendo por base a noção de experiência, através da qual o autor desenvolve uma teoria do excesso e do impossível, colocando-se num horizonte de indagação de fenômenos que escapam à normalidade do discurso racional construído sob a égide do logocentrismo.

Assim, a tese em questão pretende confrontar-se com fenômenos como o do erotismo, do êxtase, da mística, da poesia e da violência que constituem, propriamente, uma dobra do real pela via do excesso. Interessa analisar o modo pelo qual estes fenômenos de exceção são interpretados pela linguagem e criticados no campo textual.

O "louvor do excesso" a que alude o título da pesquisa diz respeito ao entendimento da noção de transgressão no pensamento e na obra batailleana. Nesse universo a transgressão é vista como um dispositivo acionado pela proibição, que lhe serve de complemento fundamental. A transgressão assim põe em funcionamento as forças heterogêneas da experiência que excedem o pensamento e o discurso. A obra de Bataille não deixa de ser um esforço geral no sentido de trazer à luz da inteligência os fenômenos da experiência, como o erotismo, a violência, a poesia, o riso, o êxtase, já que, via de regra, não são contemplados pela razão ocidental.

Palavras-chave: excesso, experiência, soberania e linguagem. 
Abstract:

In general terms, the project consists in an overview of the work of the French writer Georges Bataille, in regards to his critique of the Western reasoning, having as a base the notion of experience, through which the author develops a theory of the excess and of the impossible, that is, a horizon of questioning phenomena which escape the normality of rational discourse constructed under the aegis of logocentrism.

Thus, the thesis in question intends to confront phenomena like eroticism, ecstasy, mysticism, poetry and violence that are, properly, a fold of the real through the way of excess. It seeks to analyze the way in which these phenomena of exception are interpreted through the language and criticized in the textual field.

The "praise of excess" referred to in the title of the research relates to the understanding of the notion of transgression in the batailleana's thought and work. In this universe transgression is seen as a device triggered by prohibition, which serves as its essential complement. Transgression thus sets in motion the heterogeneous forces of experience which exceed the thought and speech. Bataille's work does not cease to be a general effort in the sense of bringing to the light of intelligence the phenomena of experience, like eroticism, violence, poetry, laughter, ecstasy, since, as a rule, these are not covered by Western reasoning.

Key words: excess, experience, sovereignty and language. 


\section{Sumário}

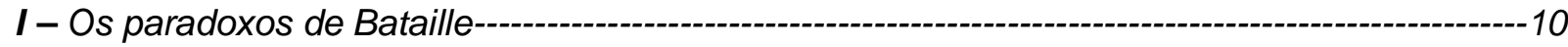

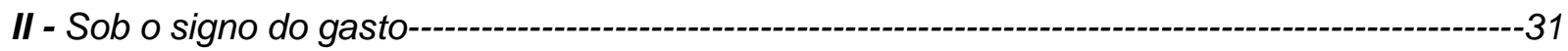

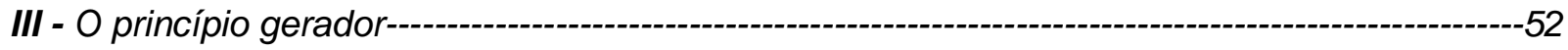

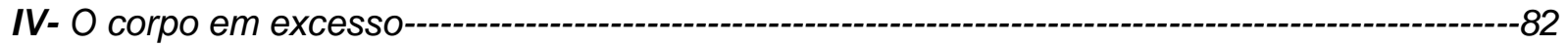

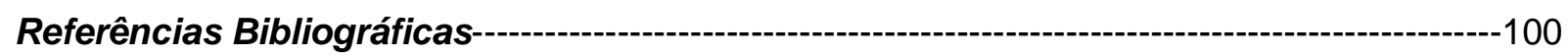




\section{I- OS PARADOXOS DE BATAILLE}

\section{"A linguagem morta" e a vontade de linguagem}

Interpretar Bataille é defrontar-se incessantemente com paradoxos, a ponto de o movimento da doxa, em planos que se afirmam lado a lado, mas que acabam se cruzando na leitura, se tornar um jogo assumido pela escrita, afinal: "escrever jamais é senão um jogo jogado com uma realidade inatingível". ${ }^{1}$

Bataille escreve desconfiando da linguagem, numa "linguagem morta", a da filosofia. A despeito disto, fala como teórico. Quando não o faz, os mesmos temas irrompem (como ervas daninhas se queremos qualificar a operação) em solo poético, nos seus textos de fiç̧ão. Segue-se, com efeito, esta advertência: "peço desculpas por partir, agora, de uma consideração filosófica. Em geral, o erro da filosofia é se afastar da vida". ${ }^{2}$ Assim, toda leitura de Bataille deve ser feita com o intuito de diminuir esta distância. Será então preciso investigar os pontos de inflexão de seu pensamento sobre as relações da linguagem com certas experiências humanas, consideradas heterogêneas, como a do erotismo, do sacrifício, do êxtase, da morte, da linguagem poética, entre outras. Tais "condutas soberanas", na expressão do autor, dizem respeito a atividades que se caracterizam por um grande dispêndio de energia, por isto mesmo denominadas "improdutivas". Nestas experiências singulares, geralmente marcadas pela violência, o corpo excede a razão. Mas haverá uma razão para o excesso?

Em Bataille, este empreendimento traz consigo ainda um dilema extra, que é o de acompanhá-lo nos movimentos em que considera a própria teoria um jogo, e, no extremo, o que parece ainda mais desafiador: como um dispositivo risível, já que o primordial do homem para ele, isto é, o que vem à tona nesse tipo de experiência, não se diz e excede todo pensamento. Desse impasse, afinal de contas, só se pode rir. Mas rir, aqui, significa reagir, manifestando-se em mais uma conduta soberana, por uma

\footnotetext{
${ }^{1}$ G.Bataille. O.C. V, Le culpable. Paris : Gallimard, 1973, p. 284.

2 G.Bataille. O.C. X, L'érotisme, id., ibid., p. 18.
} 
"figura da experiência", como diz Derrida. ${ }^{3}$ O riso, afinal, é o que expressa legitimamente a mais pura ignorância (o "não-saber", em Bataille). Assim, a interpretação corre o risco de não passar no fundo de uma teoria do riso, exercício não de todo inútil, mas incapaz de responder àquilo que no, como Ihe chama Bataille, "homem", se manifesta como excesso e violência e que, ao mesmo tempo, pede passagem à linguagem.

Se a história da civilização é também a do controle da violência pela linguagem, como afirma Bataille, herda-se uma negatividade que se faz presente o tempo todo, isto é, se reconstitui de algum modo em cada ato de linguagem (ou de silêncio, que esta dispõe a seu favor) apesar da vigilância das instituições que a razão erigiu como apanágios de lei e verdade.

É possível então retomar este autor a partir mesmo de seus paradoxos, já que ele recorre ao expediente de empregar o discurso para renegar o próprio em nome daquilo que o excede, colocando-se afinal, para todo efeito, como aliado da razão. Portanto, em Bataille, a escrita se produz simultaneamente como crítica do discurso e exploração de suas margens. Eis a vontade de linguagem que ressoa nesta obra, tomando a forma de uma indagação permanente sobre os acontecimentos, os quais, diz ele, colocam "o homem em questão". Se for impossível encontrar para tais experiências heterogêneas um equivalente em sentidos, em explicação conceitual no plano da filosofia, isto é, no que se transmite como verdade de discurso e saber, há que se estabelecer ao menos para toda heterogeneidade um campo de referências, um espaço em que interrogá-las seja um exercício intelectual vigoroso.

Interessa pensar a vida, sobretudo nas circunstâncias em que o excesso está diretamente ligado a ela, até na morte, enfim, o que em relação ao homem se mostra refratário aos dispositivos da racionalidade nas formas que secularmente foram tomando em discursos e saberes da filosofia e da ciência. Não há como ignorar o excesso e sua exigência. A propósito:

No jogo que excede a natureza, é indiferente que eu a exceda ou que ela própria se exceda em mim (ela pode ser inteiramente excesso dela 'mesma,);

\footnotetext{
${ }^{3}$ J. Derrida, « De l'économie restreinte à l'économie générale », in L'écriture et la différence. Paris : Seuil, 1967, p.
} 376. 
mas, com o tempo, o excesso se insere finalmente na ordem das coisas (e neste momento eu morro). ${ }^{4}$

O excesso é esta força que supera o que quer que seja, venha de onde vier, de fora ou de dentro do homem. O excesso é perpétuo devir. Nenhum discurso o contém, nenhum saber o detém. Tal movimento responde por si e só se rende a si mesmo, numa relação de forças em que a mais forte sempre supera a mais fraca. Se há um limite para o excesso, existe sempre a possibilidade de um excesso ainda maior poder suplantá-lo, e assim por diante. A cada ato excessivo supera-se um limite e ao mesmo tempo se assinala outro, que via de regra é excedido depois.

Daí os temas recorrentes de Bataille não se encontrarem na linha de frente da pesquisa filosófica, não se constituindo propriamente em questões dessa especialidade, a despeito de sua veemência e de seu apelo. A filosofia "não pode tudo", mantendo-se num campo estrito de possibilidades. Como então pensar o excesso? A tentação de Bataille é mostrar que toda teoria só é possível tomando por base a força do excesso. Isto fica patente, aliás, em $A$ parte maldita, que segundo Jean Piel,

é o único livro [...] onde ele teria tentado construir uma exposição sistemática de sua visão do mundo: filosofia da natureza, filosofia do homem, filosofia da economia, filosofia da história. É sempre a noção de excesso que está na base dessa construção. ${ }^{5}$

Como se vê, a reticência de Bataille em relação à Filosofia acaba motivando-o a uma especulação nada modesta que testemunha o quanto sua recusa dos dispositivos racionais o leva a sobrepujar ao máximo, por causa do excesso, uma interpretação do mundo, valendo-se das potencialidades da razão. Vale dizer, ainda é pelo conhecimento que ele trabalha, mesmo que seus objetos escapem ao controle do intelecto, resistindo ao conceito e à sua fixação por meio do discurso, respondendo no fundo ao "não-saber", ou ao "impossível". De modo que toda leitura de Bataille oferece um conjunto de noções que atestam a supremacia do excesso na base das operações humanas. Da base ao topo, é bom frisar, levando em conta esta potência como

\footnotetext{
${ }_{5}^{4}$ G.Bataille, O.C. III, L'impossible, p. 219.

5 J. Piel, "Introdução", in G. Bataille, A parte maldita. Rio de Janeiro: Imago, 1975, p. 19.
} 
princípio do pensamento e modo de intensificação dos seres e de suas relações no mundo.

Há também, com efeito, a questão de Espinosa na Ética, que parece consonante com o pensamento de Bataille: "o que pode um corpo"? Eis um modo de nos aproximarmos da experiência a partir da indagação de tudo o que um corpo pode fazer ou não, o que implica a atividade decorrente da potência de ser. "O que pode um corpo" também responde por seus limites e coloca as disposições vitais numa experiêncialimite, abrindo para o excesso através do qual o homem atua no erotismo e na relação com a morte, assim como nestas circunstâncias desloca a representação do sujeito como centro, desativando o campo de força da consciência. Eis o acontecimento em que o sujeito vivencia o gozo de sua própria ruína. O excesso, que é um modo de ser da violência, efetua a experiência-limite do corpo numa operação de gasto, dépense, que por se dar à revelia de qualquer controle e ater-se exclusivamente à própria "autoridade" da experiência, como diz Bataille, pode ser considerada soberana. Mas como entender propriamente estas experiências do erotismo, do sacrifício, do êxtase? São acontecimentos ${ }^{6}$ no mundo social, religioso e pessoal, que se distinguem como singularidades, e se aproximam uns dos outros enquanto formas heterogêneas de despesa. Mas seriam exceções? Finalmente, como pensar o que excede o pensamento e o discurso?

Ora, a violência também está no pensamento, que se serve dela quando quer (e com que freqüência e destreza o faz!): "mesmo o pensamento (a reflexão) só se realiza em nós no excesso". 7 Eis o melhor argumento de que poderia se servir Bataille. As relações humanas, o mundo fora delas, nada está livre da violência; ela parece estar mesmo em tudo o que se pensa ou se faz. A violência é um efeito da potência. O texto essencial que nos permite extrair tal afirmação é o seguinte:

O mundo do trabalho e da razão é a base da vida humana, mas o trabalho não nos absorve inteiramente; e, se a razão ordena, nossa obediência tem limites. Por meio de sua atividade, o homem edificou o mundo racional, mas nele

\footnotetext{
${ }^{6}$ Um tipo especial de "acontecimento", pensado como a irrupção de uma singularidade na vida humana. Nesse sentido, o termo aqui empregado se aproxima de Foucault, entendido à maneira de um "atravessamento". Assim, "o repetimos [o acontecimento] em nossa atualidade e procuro destacar o acontecimento sob o signo do qual nascemos e aquele que continua ainda a nos atravessar". V. J.Revel, Le vocabulaire de Foucault, Paris: Ellipses, 2002, pp. 3032. Em Bataille, portanto, o termo acontecimento refere à experiência desse atravessamento na esfera da subjetividade, que coloca o ser em questão.

L'érotisme, op. cit., p. 262.
} 
sempre subsiste um fundo de violência. A própria natureza é violenta e, por mais razoáveis que tenhamos nos tornado, uma violência que não é mais a natural pode nos dominar novamente: a violência de um ser racional, que tentou obedecer, mas sucumbe ao movimento que nele próprio não pode se reduzir à razão.

Há na natureza, e subsiste no homem, um movimento que sempre excede os limites e só pode ser reduzido parcialmente. Geralmente não podemos nos dar conta desse movimento. Ele é mesmo, por definição, aquilo do qual nada pode dar conta, mas vivemos sensivelmente sob seu poder: o universo onde vivemos não responde a nenhuma faculdade delimitada pela razão, e se tentamos fazer com que Deus responda por ela, só fazemos associar, desrazoavelmente, o excesso infinito em presença do qual está nossa razão, com esta razão. Mas, pelo excesso que está nele, esse Deus de quem gostaríamos de formar a noção apreensível não cessa, excedendo essa noção, de exceder os limites da razão. 8

Registre-se primeiro a tentativa de solapamento da violência pelo mundo da racionalidade e do trabalho, o "mundo homogêneo", na expressão de Bataille. Mas a própria atividade produtiva, derivada de um processo racional secular, que também se tornou um modo de controle do excesso, é incapaz de gerar sempre a si mesma, dando margem à manifestação das forças que no homem contestam o funcionamento homogêneo da vida pela regulamentação do trabalho. A violência atua aqui como um princípio que impele o homem a exceder limites pela via das experiências heterogêneas, como a do erotismo, do sacrifício e do êxtase. Em termos hegelianos, que em geral funcionam como um pano de fundo nas reflexões de Bataille, mas bem a seu modo, a história do homem é a história de seu trabalho, e este trabalho, como observa Kojève "só é histórico, social, humano, sob a condição de se efetuar contra o instinto ou o 'interesse imediato' do trabalhador; o trabalho deve se efetuar a serviço de um outro, e deve ser um trabalho forçado, estimulado pela angústia da morte". 9 Entretanto, isto não parece suficiente, e, como afirma Bataille, "uma violência que não é nada além da violência natural pode nos dominar novamente". O ponto especialmente relevante é que o excesso aí atua como um princípio de soberania e libera "a violência de um ser racional, que tentou obedecer, mas sucumbe ao movimento que em si próprio não pode reduzir à razão". O excesso gera a desobediência enquanto efeito da violência natural num ser dotado de razão, o qual excede seus próprios limites, ou seja, aqueles estabelecidos racionalmente pelo mundo homogêneo do trabalho produtivo.

\footnotetext{
${ }^{8}$ Id., lbid., pp. 43-44.

${ }^{9}$ A. Kojève, Introduction à la lecture de Hegel. Paris: Gallimard,1947, p. 30.
} 
Sob o princípio de excesso, o indivíduo gera violência levando a razão a agir contra a razão, mas fundando com isto todo o campo das experiências heterogêneas que se caracterizam por um movimento de dispêndio de energia, desviada da atividade produtiva. Há modos de vida ao longo da história humana que enfatizam o caráter soberano em sua conduta. $O$ homem passa então a consumir, gastar, dilapidar suas reservas ao invés de produzir e acumular. Do ponto de vista econômico, o gasto ou despesa, dépense, é o efeito último que a potência do excesso provoca na esfera das relações humanas por meio das quais se consomem seres e coisas num âmbito de morte e ruína. A principal fonte, aqui, utilizada por Bataille, é o Ensaio sobre a dádiva, de Marcel Mauss, que via na prática do potlatch em certas tribos do Noroeste norteamericano, da Melanésia e da Polinésia, entre outros povos, um princípio de economia e de soberania, por meio do qual tribos rivais se sucediam em depredações contínuas de seus bens que também eram dados de presente de modo a se exibirem, se medirem e se superarem mutuamente:

Em parte alguma o prestígio individual de um chefe e o prestígio de seu clã estão mais ligados ao dispêndio e à exatidão em retribuir usurariamente as dádivas aceitas de modo a transformar em obrigados aqueles que os obrigaram. Aqui, o consumo e a destruição são realmente sem limites. Em certos potlatch deve-se gastar tudo o que se tem e nada conservar. É uma disputa de quem será o mais rico e também o mais loucamente perdulário. $O$ princípio do antagonismo e da rivalidade está na base de tudo. $O$ estatuto político dos indivíduos, nas confrarias e nos clãs, as posições de todo tipo se obtém pela 'guerra de propriedade' assim como pela guerra, ou pela sorte, ou pela herança, pela aliança e o casamento. Mas tudo é concebido como se fosse uma 'luta de riqueza'. O casamento dos filhos, o assento nas confrarias só se obtêm ao longo de potlatch trocados e retribuídos. Os bens se perdem no potlatch como são perdidos na guerra, no jogo, na luta. Em alguns casos, não se trata sequer de dar e de retribuir, mas de destruir, a fim de nem mesmo querer dar a impressão de desejar ser retribuído. Queimam-se caixas de óleo de olachen (candle-fish), peixe-vela) ou de óleo de baleia, queimam-se casas e milhares de mantas; os cobres mais caros são rompidos, atirados n'água, para esmagar, para 'fazer calar' o rival. ${ }^{10}$

Para Bataille, o potlatch é uma prática que comprova o quanto a cultura assimilou o excesso como um princípio vital em sua dinâmica de modo a restabelecer a ligação do homem com a vontade de potência. Por meio do potlatch, ou dádiva, certos povos

\footnotetext{
${ }^{10}$ M. Mauss, "Ensaio sobre a dádiva”, in Sociologia e Antropologia. São Paulo: Cosac \& Naify, 2003, pp. 238-240.
} 
regulam sua vida econômica, jurídica, política e religiosa. O excesso é assim reintroduzido nos diversos níveis da vida social, reafirmando seu modus operandi.

O princípio do gasto representa uma inversão nas relações entre o homem e o trabalho. Quando se trabalha demais pela produção e pelo crescimento, atinge-se um excedente que é o único modo da potência do excesso continuar gerando; ou seja, sem poder empregar o quantum de energia no trabalho, ela se torna "negatividade sem emprego", nos termos de Bataille, desviando-se da finalidade produtiva. Tal excedente então conflui para as condutas heterogêneas da experiência sob um princípio de gasto.

Eis o movimento que arrebata quem trabalha, sem que ele, no geral, tenha consciência disto e com o fator determinante, para Bataille, de que "vivemos sensivelmente sob o seu poder". Se a razão é dotada de atributos de uma potência que orienta o homem em todos os campos em que seja possível a indagação ou a investigação, a razão mesma revela-se impotente para conter todas as forças atuantes no universo, o qual, para todo efeito, "não responde a nenhuma" dessas faculdades. Resta, no entanto, a mais emblemática das figuras da metafísica: Deus. Se a razão não pode responder pelo universo, "tentamos fazer com que Deus responda por ela". Deus passa a servir de anteparo ao próprio excesso universal, último recurso humano para conter as forças heterogêneas da violência e superá-las; Deus é, assim, posto no lugar da razão para salvá-la da violência, do excesso, da ruína do homem e de sua espécie. O problema é que, nessa tentativa desesperada, perde-se a razão associando-se o "excesso infinito em presença do qual está nossa razão, com esta razão". Contudo, na mais desmedida das manobras, "pelo excesso que está nele, esse Deus de quem gostaríamos de formar a noção apreensível não cessa, excedendo essa noção, de exceder os limites da razão". Deus assim se funde na potência do excesso infinito, somando-se a ele e desaparecendo do entendimento para afundar na obscuridade. É nessa condição que ele irá "reaparecer" ao homem dotado de razão, mas também de fé, como "todo-poderoso, eterno, infinito". Afinal, o homem transferiu a "Ele" sua potência e "Ele" terá de responder por ela. Deus é o momento culminante dessa relação do homem com o excesso, mas também será a noção responsável, para Bataille, como também para Nietzsche, pelo seqüestro da divindade do homem, por tudo o que ela tem de excessiva, servindo para reforçar as interdições e regular as práticas sociais 
com um controle duradouro de todas as formas de violência. A verdade da violência, para Bataille, é também a verdade do erotismo. E, sobre Deus,

o que o misticismo não pode dizer (no momento de dizê-lo, enfraqueceu), o erotismo o disse: Deus não é nada se não for a ultrapassagem de Deus em todos os sentidos; no sentido do ser vulgar, no do horror e da impureza; finalmente no sentido de nada... ${ }^{11}$

Deste modo, a potência do excesso continua atuando, para além de Deus, mas também a despeito dele, uma vez que excede tal noção já extremada em si mesma. Nada contém o excesso e o excesso excede tudo. No excesso, o corpo erótico ultrapassa a si mesmo, recusando os limites estabelecidos pela razão no mundo homogêneo do trabalho produtivo. No excesso o erotismo se comunica com a morte, buscando continuidade, já que ele é, como expressa a formulação de Bataille: "a aprovação da vida até na morte". ${ }^{12}$ A morte assinala um limite para o excesso. Mas, ela mesma, a mais improdutiva das atividades, pode ser vista como um momento de máxima intensidade vital (como num cadáver proliferando vermes) em que o excesso é força propulsora, sob um princípio de gasto sem reservas. O cadáver em putrefação é, assim, o signo hiperbólico desse contraste.

No pensamento de Bataille, Deus é destituído de sua soberania. Deposto, não passa de uma noção vazia, de um tapa-buraco sem sentido, e é deslocado para o nada. Afinal,

No lugar de Deus...

só existe

o impossível,

e não Deus. ${ }^{13}$

O "impossível" é a noção em Bataille que responde pelo excesso, justamente porque Deus não pode conter o excesso, livrando o homem de todo mal, sem se contradizer como a maior das potências, tendo, neste caso, impreterivelmente, que exceder a si

\footnotetext{
${ }^{11}$ L'érotisme, op. cit.,pp. 262-263.

12 Id., ibid., p. 17.

${ }^{13}$ O.C.III, Le Petit, p. 47.
} 
mesmo. Deus não pode barrar o movimento do excesso sem ser arrastado por ele, nem se identificar com o seu ponto máximo de energia, aquilo que, enquanto gasto, se poderia chamar de potência do excesso. Deus só pode ser o ponto culminante de um limite, o limite dos limites no plano universal das religiões. Em relação ao excesso, ao qual é exterior, Deus é como um dique barrando um furacão incontrolável, assimilado ao excesso ele mesmo, e que diversas vezes na história das religiões é cultuado, sacralizado.

De fato, de divina, a potência muitas vezes passa a ser considerada diabólica, qualificando-se com isso toda força como mal absoluto. Nas religiões monoteístas, Deus é a figura forjada para limitar a potência no domínio moral, religioso e também econômico, conforme critérios bem definidos por grupos poderosos, para pensar como Nietzsche. Tal ideia de Deus limita a potência do excesso, dessacralizando o homo religiosus para adaptá-lo ao mundo homogêneo, e entendendo-o como reprodutor da violência. Com isso, o sagrado torna-se um interdito e as práticas religiosas que dão vazão às forças heterogêneas pelas experiências do erotismo, da festa, do sacrifício, do êxtase, são confinadas num espaço de exceção. O mundo homogêneo não neutraliza as forças heterogêneas, dada a natureza soberana delas, mas diminui seu impacto. Veremos mais adiante que apesar disto o excesso exige sempre violência, tornando imprevisível e incontrolável o mecanismo das forças heterogêneas e as condutas, conduites da experiência, as quais, sintonizadas com a potência, só respondem a si mesmas, pois a potência em si não tem sentido nem finalidade.

Do paradoxo de pensar o impensável, a experiência que excede o pensamento, de dizer o indizível pela via da linguagem, o que ultrapassa os limites do discurso, chega-se a um paradoxo cavado mais fundo na vida, nos limites mesmos da antropologia, ao menos da francesa, referência maior de Bataille, em estudiosos como Durkheim, Mauss e Roger Caillois, seu amigo, para quem "pode-se desenhar uma espécie de geografia social do puro e do impuro". ${ }^{14}$ Nos termos de Bataille, o "puro" e o "impuro" correspondem respectivamente ao "mundo homogêneo" e ao "mundo heterogêneo", do qual emana a vontade de excesso. O mundo homogêneo da pureza e da ordem tenta se defender do contágio dos elementos malignos da violência, como a

\footnotetext{
${ }^{14}$ R. Caillois, L'homme et le sacré. Paris: Gallimard, 1950, p. 65.
} 
sujeira do erotismo e da morte. Da relação entre os dois mundos, Bataille desenvolve a noção de heterogeneidade, um de seus poucos conceitos filosóficos de fato, na opinião de Michel Surya. ${ }^{15}$

\section{Dois mundos}

Homogeneidade / heterogeneidade. A barra que separa as duas noções operacionais de Bataille só as opõe propriamente num âmbito estritamente simbólico. Enquanto tal funciona como a da interdição / transgressão, outra dualidade seminal de seu pensamento, ou seja, como uma relação complementar, como se verá mais tarde. As ligações entre ambas são simétricas e se fundam na noção de excesso. Tanto em uma quanto em outra polaridade, se estabelecem relações ao mesmo tempo de convergência e de divergência, de negação e de afirmação, de barragem e de atravessamento, de continuidade e descontinuidade.

Mas como esta fronteira funciona? Por um lado, ela é um artifício para proteger o mundo homogêneo das forças heterogêneas. O mundo homogêneo regula as práticas sociais, econômicas, religiosas, com o intuito de conter a violência que irrompe do mundo heterogêneo. Do ponto de vista econômico, a homogeneidade explicita o binômio produção-consumação, sendo que o termo "consumação", aqui, se restringe ao necessário, à sobrevivência. Por outro lado, a fronteira é um engodo e serve para ativar as forças heterogêneas derivadas da potência do excesso que vêm à tona nas experiências do erotismo, do riso, da festa, do sacrifício, do êxtase, entre outras, exigindo gasto, num movimento de pura perda. É por isso que Bataille as considera soberanas.

A homogeneidade está ligada aos valores da economia pensada como crescimento e produção, cuja unidade básica ou medida comum é o dinheiro. Todo investimento e aquisição de recursos visam, classicamente, ao controle da produção e o crescimento. O mundo homogêneo recusa a abundância desvinculada da produção. Seu lema é aquele em que "o pródigo será sempre um inimigo público, e o homem

\footnotetext{
${ }^{15}$ M.Surya, Georges Bataille: la mort à l'oeuvre. Paris : Gallimard, 1992, p.566
} 
frugal um benfeitor público". ${ }^{16}$ Mas este controle não se mantém o tempo todo. Como diz Bataille, a atividade produtiva não absorve inteiramente o homem. Este mesmo mundo que regula a vida pelo trabalho também é dado ao esbanjamento: "o princípio que leva a gastar é a paixão pelo gozo imediato, a qual, embora seja às vezes violenta e difícil de ser contida, em geral é apenas momentânea e ocasional". 17 A "paixão pelo gozo imediato", em Bataille, está correlacionada ao excedente de energia desviado da produção, implicando a vontade de excesso, cuja violência subsiste na natureza e no homem. Ainda que o esbanjamento surja como episódico, na visão de Smith, não deixa de acusar, portanto, um efeito heterogêneo na economia.

A razão erige o mundo do trabalho e o institucionaliza por meio de discursos e conhecimentos. Ao mesmo tempo, não pode evitar as forças heterogêneas que se manifestam na experiência e requerem excesso. Este excedente tem de ser despendido, consumado a todo custo, dos mais diferentes modos: festas, orgias, guerras, sacrifícios, efusão extática, efusão poética, etc.

No ensaio "A estrutura psicológica do fascismo", Bataille volta a diferenciar estes dois aspectos, os quais, na estrutura do social, representam a homogeneidade e a heterogeneidade. A produção constitui a base da sociedade homogênea, cujo aspecto produtivo é a utilidade. Nesta sociedade, o dinheiro serve de medida para todo trabalho e torna o homem uma função de produtos mensuráveis. ${ }^{18}$ Daí a lógica de desempenho que rege o mundo homogêneo aliando trabalho produtivo e tempo organizado. $A$ consciência é um dispositivo desta racionalidade que liga o homem que produz, portanto, o homem útil, ao projeto, o qual, como afirma Sasso, "nos limita à finitude de um telos" ${ }^{19}$ Com base num projeto, o homem vive na perspectiva do futuro ideal, de satisfação plena, livre de toda ameaça, e ainda com esperança de salvação após a morte. A religião e os valores da transcendência reafirmam as disposições gerais do mundo homogêneo em preservar-se regrando a vida dos indivíduos e constituindo para eles um espaço de exceção para onde canalizam as demandas heterogêneas que interferem no social. A igreja, neste sentido, é uma instituição exemplar do mundo

\footnotetext{
${ }^{16}$ A. Smith, An Inquiry into the Nature and Causes of the Wealth of Nations. London: William Benton, Publisher, 1952, p. 147.

17 Id., Ibid.

${ }^{18}$ O.C. I, La structure psychologique du fascisme, p. 340.

${ }^{19}$ R. Sasso, Georges Bataille: le système du non-savoir. Paris: Minuit, 1978, p.110.
} 
homogêneo, regulando a violência das forças heterogêneas e a vontade de gasto por uma economia do sagrado. Mas a experiência da heterogeneidade não se confina apenas ao espaço da igreja. Ela encontra outras formas de se manifestar, como no erotismo, no riso, no êxtase, já que responde sempre a uma exigência do excesso. As experiências heterogêneas exigem comunicação, noção fundamental em Bataille a qual voltaremos mais de uma vez. A comunicação é a via soberana da experiência. Confundindo existência e trabalho (o pensamento discursivo, o projeto), a filosofia de Hegel "reduz o mundo ao mundo profano", ${ }^{20}$ negando o mundo sagrado, que para Bataille se constitui como experiência soberana na comunicação entre os seres numa determinada comunidade. A noção de experiência excede o saber do trabalho e do projeto: "a construção de Hegel é uma filosofia do trabalho, do 'projeto'. O homem hegeliano - Ser e Deus - realiza-se, completa-se na adequação do projeto". ${ }^{21} \mathrm{O}$ mundo homogêneo encontra em Hegel o seu filósofo, aquele que projeta em discurso o grande sistema do saber universal.

\section{A consumação de si}

No mundo homogêneo, o homem tem Deus no pensamento e fé no projeto como instância reguladora da vida, mas é reduzido à categoria das coisas. Tal condição não dá margem às exigências da subjetividade, a não ser excepcionalmente, no contexto religioso. Entretanto, o mundo homogêneo exclui da vida social as condutas soberanas que dão vazão à heterogeneidade.

O indivíduo que se desvia do trabalho, desfuncionaliza a energia, liberando-a para despesas improdutivas; torna-se, ao contrário, um receptáculo de forças heterogêneas. A soberania, em Bataille, é a condição plena da heterogeneidade. Nesse sentido, para ele, o ser soberano é aquele que vive inteiramente nos extremos do excesso e na consumação de si mesmo. $\mathrm{Na}$ análise de Habermas:

\footnotetext{
${ }^{20}$ O.C. V, L'expérience intérieure, p. 96

${ }^{21}$ Id., ibid., p. 96.
} 
Ser soberano significa não se deixar reduzir, como no trabalho, ao estado de uma coisa, mas desenvolver a subjetividade: afastado do trabalho e tomado pelo momento, o sujeito se esgota no consumo de si mesmo. A essência da soberania consiste no consumo inútil, naquilo 'que me agrada'. No entanto essa soberania é condenada por um processo histórico-universal de desencantamento e coisificação. ${ }^{22}$

A experiência é propriamente o acontecimento principal da heterogeneidade. Através dela, as condutas soberanas do erotismo, do sacrifício, do êxtase, trazem à tona o fundo de violência subsistente no homem, dando vazão aos gastos da subjetividade, a qual, desviada da atividade produtiva, se expande, e o indivíduo se consuma em gozo íntimo e pura perda. $\mathrm{O}$ abandono ocasional do trabalho faz o indivíduo perseverar na inoperância e ativar as forças heterogêneas do excesso. A experiência da heterogeneidade resulta em extrema angústia para o sujeito, que entra em crise, consumando-se em si mesmo. Trata-se de um acontecimento à revelia do saber, e mesmo contra qualquer tipo de saber: "Conhecer significa: relacionar ao conhecido, apreender que uma coisa desconhecida é a mesma que outra conhecida". 23 Mas o que é o êxtase? Não se pode relacioná-lo a nada conhecido. Como saber o que se passa numa conduta heterogênea que justamente é soberana por não se reduzir ao conhecimento e à consciência, instrumentos do saber da produção e da produção do saber? Como trazer para o conhecimento o que é da experiência do "não-saber"? A experiência, certamente, é sensibilia, não sapientia, e esta sensibilidade, em si mesma, é "contestação" do saber:

\begin{abstract}
A experiência só seria um logro, se ela não fosse revolta, em primeiro lugar, contra o apego do espírito à ação (ao projeto, ao discurso - contra a servidão verbal do ser razoável, do doméstico), em segundo lugar contra o apaziguamento, as suavidades que introduz a própria experiência. ${ }^{24}$
\end{abstract}

Por essa conduta, o indivíduo já não pertence ao espaço de trabalho, perdendo toda noção de homogeneidade; ele se encontra no "extremo do possível". O extremo do possível é o começo mesmo do impossível, ou a instância última do limite. É nesse

\footnotetext{
22 Jürgen Habermas, "Entre erotismo e economia geral: Bataille", in O discurso filosófico da modernidade. São Paulo: Martins Fontes, 2002, p. 31.

${ }^{23}$ O.C. V, L'expérience intérieure, p. 127 [ed. Bras. A experiência interior. São Paulo: Ática, 1992, p. 116]

${ }^{24}$ Id., ibid., p. 134 [ed. bras. p. 123].
} 
ponto que a experiência se constitui como recusa do conhecimento, recusa por excesso. De onde vem o êxtase? A resposta de Bataille: "o não-saber comunica o êxtase". ${ }^{25}$ Mas isso somente se o "movimento" do êxtase "já pertencesse, em qualquer grau, àquele que se desveste do saber". ${ }^{26} \mathrm{O}$ condicional, aqui, reafirma a impossibilidade de saber da experiência extática, na medida em que mantém o leitor grudado ao inteligível da hipótese. Mas Bataille fala daquele "que se desveste do saber". E aqui, cabe avançar um pouco, se quisermos compreender melhor a operação soberana que diz respeito inteiramente ao caráter do improdutivo por força da heterogeneidade e cuja conduta aponta para o sentido mesmo da transgressão: "em tal momento e neste limite, isto é possível", ${ }^{27}$ ou seja, de fora de qualquer Herrschaft, quando, alheio a qualquer dominação, o corpo reage, isto é, potencializa-se na soberania da experiência gerando excesso e se consumando em pura perda. Toda esta operação se faz à revelia do conhecimento. É a ocasião em que fatores exteriores ao trabalho produtivo, como o não-saber, a sorte, chance, o instante, as forças heterogêneas, convergem para o acontecimento singular da experiência.

O que não desempenha função alguma no processo da produção constitui uma figura-chave da obra de Bataille: o improdutivo. Efetivamente, sua singularidade não está no fato de ser inaproveitável ao sistema produtivo, mas em constituir um excedente de energia, em atualizar a potência do excesso, recusando todo saber do trabalho e todo trabalho do saber, e viabilizar, desde modo, uma experiência-limite. Expondo o homem às condições que o tornam demasiado humano, Bataille se filia a Nietzsche, vínculo tão claro, como muitas vezes incensado, pois o que representa o excedente improdutivo senão vontade de excesso, isto é, o que se pode definir, no extremo, como um querer mais para além de todo limite?

O improdutivo se vê assim investido de um estranho poder, de uma estranha liberdade, além de parecer ter adquirido, ainda que momentaneamente, uma descomunal sintonia com a potência, denominação esta que Nietzsche, em carta, ${ }^{28} \mathrm{diz}$ preferir ao termo "felicidade", noção vaga e sem sentido, aliás, como tantas outras:

\footnotetext{
${ }^{25}$ Id., ibid., p. 143 [ed. bras. p. 131].

${ }^{26}$ Id., ibid., p. 144 [ed. bras. p. 132].

27 O.C. X, L'érotisme, p. 68 [ed. bras. p.105].

28 V. P.Klossowski, Nietzsche e o círculo vicioso. São Paulo: Pazulin, 2000.
} 
"espírito", "alma", "razão", celebrizadas pela metafísica e não por acaso recorrentes no vocabulário do mundo homogêneo.

O indivíduo improdutivo reage "passivamente", como afirma Bataille, sem controle da consciência. A passividade é a descrição física da inoperância, pois nesse momento o corpo se encontra sob ação das forças heterogêneas do excesso, reagindo internamente a ela, como na efusão extática. A experiência do êxtase, denominada "experiência interior", abre-se para o impossível na medida em que recusa o conhecimento. Eis como Bataille descreve a operação soberana do êxtase:

O movimento anterior ao êxtase do não-saber é o êxtase frente a um objeto (que este seja o ponto puro - como o exige a renúncia às crenças dogmáticas, ou alguma imagem perturbadora). Se este êxtase frente ao objeto é inicialmente dado (como um possível) e se suprimo, mais tarde, o objeto - como o faz fatalmente a "contestação" - se, por esta razão, entro na angústia - no horror, na noite do não-saber - o êxtase está próximo e, quando ele acontece, derrubame mais longe do que nada imaginável. ${ }^{29}$

Contra o trabalho do saber, contra o conhecimento enquanto produto desse trabalho, a experiência do êxtase se confunde com a própria contestação. O sujeito em crise (de angústia, de horror, ante a dissolução de si mesmo) precipita o êxtase enquanto se afirma, soberanamente, como negatividade sem emprego, contra a razão homogênea.

Em contrapartida, o mundo organizado do trabalho tende a rejeitar as atividades incompatíveis com a produção. A experiência tem seu tempo próprio e só responde a si mesma. Por meio de instituições, como a do matrimônio, o mundo homogêneo regula as práticas sexuais. O sexo é visto como atividade produtiva, visando à procriação. Seu caráter improdutivo, na conduta soberana do erotismo, conduta violenta, desmedida e dispendiosa, tende a ser neutralizado, domesticado, e sua operação de gasto resvala na indiferença, sem maiores conseqüências. O mesmo ocorre com outras condutas soberanas sob efeito de heterogeneidade: "no domínio da homogeneidade, só há repercussões de subversão, na medida em que a estabilidade deste domínio depende de regras gerais de opressão estabelecidas numa sociedade determinada". ${ }^{30}$

\footnotetext{
${ }^{29}$ O.C. V, L'expérience intérieure, p. 144 [ed. bras. p. 132].

${ }^{30}$ O.C. II, «L'abjection et les formes misérables », in Essais de sociologie, p. 217.
} 
Além do dinheiro, medida comum e fundamento do mundo homogêneo, as formas mais acabadas e expressivas que produz são as ciências e as técnicas. ${ }^{31} \mathrm{Com}$ isso, toda atividade improdutiva, todo elemento inútil, se não são excluídos da sociedade como um todo, encontram-se sob controle e vigilância permanente. Como resultado, passam a constituir as interdições do mundo social. Daí, segundo Bataille, a impossibilidade de Durkheim achar uma definição científica para o sagrado. ${ }^{32}$ Não há como enquadrar o sagrado numa categoria rigorosamente objetiva, vale dizer, científica, tendência esta, aliás, durkheimniana, em tentar pensar os acontecimentos humanos como coisas $\mathrm{O}$ sagrado constitui uma singularidade apartada do saber científico do mundo homogêneo. Não apenas isso: o sentido do sagrado que a heterogeneidade comunica representa uma força desconhecida e perigosa "que uma certa proibição social de contato (tabu) separa do mundo homogêneo ou vulgar (que corresponde ao mundo profano da oposição estritamente religiosa)". ${ }^{33}$ No limite, a interdição em torno do sagrado representa a intolerância do mundo homogêneo em relação àquilo que vincula o homem à experiência do erotismo e da morte. Este vínculo pode ser pensado como uma experiência do excesso em si mesma.

A heterogeneidade expressa o sentido imanente do excesso. "Viver o excesso, é viver esta superabundância jamais contida, jamais dominada". ${ }^{34} \mathrm{O}$ excesso responde pela exuberância da vida, pois determina as condutas soberanas que se consumam na experiência:

A história da vida sobre a terra é principalmente o efeito de uma louca exuberância: o acontecimento dominante é o desenvolvimento do luxo, a produção das formas de vida mais onerosas. ${ }^{35}$

Assim, o impulso heterogêneo do social concerne àquilo que dispõe o homem numa relação imediata com a vida, isto é, torna a vida levada ao extremo uma experiência de consumação do corpo. É deste modo que "seres descontínuos", como diz Bataille, realizam uma experiência de continuidade; a continuidade é o sentido que as relações

\footnotetext{
${ }^{31}$ O.C. I, La structure psychologique du fascisme, p. 340.

32 Id., lbid., p. 345.

33 Id., ibid., p. 346.

${ }^{34}$ Arnaud e Excoffon-Lafarge, Bataille. Paris : Seuil, 1978, p. 72.

${ }^{35}$ Bataille, O.C.VII, La part maudite, p. 40.
} 
entre os corpos adquirem quando se colocam na via excessiva das experiências do sacrifício, do erotismo, da poesia, do êxtase, das condutas marcadas pela violência. Se, no limite, tais experiências não se distinguem da consumação, é que esta é a experiência comum de todas as condutas soberanas efetuadas sob o princípio do gasto. Para Bataille, a propósito, isto constitui a autoridade da experiência. A consumação de si não se faz em confirmação de um saber e de sua autoridade, mas em razão da autoridade própria da experiência que em seu ato desautoriza qualquer outro saber. A medida dessa autoridade, por meio da qual as relações com a vida são levadas às ultimas conseqüências, é o excesso, ou seja, a medida da intensidade que em si mesma é desmedida (como na hybris grega), que explicita serem as condutas soberanas do corpo experiências de continuidade e de consumação. A autoridade da experiência imanente e a soberania dessas condutas afastam os corpos da atividade produtiva, levando-os a perseverar na subjetividade e a se consumar por uma "jubilosa necessidade" (freudiger Notwendigkeit), como se lê em Nietzsche. ${ }^{36}$ A relação com o tempo, aqui, também é outra: vive-se na indeterminação; não no horário estipulado pelo trabalho produtivo, o do emprego utilitário, mas no exigido pelo acontecimento soberano, ao menos em duas instâncias singulares da experiência: a do instante e a da sorte. O mundo heterogêneo irrompe, substituindo a atividade do trabalho, que funcionaliza, distribui e limita o dispêndio da energia humana das operações do jogo, que amplia o espaço inoperante da experiência e da subjetividade, no qual o indivíduo soberano se consuma.

Generalizando ainda mais estas relações, a desmedida e a embriaguez configuram o modo de ser originário do homem.

"O sagrado representa o mundo íntimo e imanente, o profano o mundo mediato e transcendente: o mundo íntimo se opõe ao mundo real como a desmedida à medida, a loucura à razão, a embriaguez à lucidez".

Em Bataille, tal recorte enfoca o momento em que a cultura, erigida pela consciência e pelo trabalho, afasta o homem de uma relação imediata e intensa com a

\footnotetext{
${ }^{36}$ F. Nietzsche, Die Geburt der Tragödie aus dem Geiste der Musik, in Gesammelte Werke. Bindlach: Gondrom, 2005, p. 11 [ed. bras. O nascimento da tragédia ou helenismo e pessimismo. São Paulo: Companhia das letras, 1999, p. 29].

${ }^{37}$ M.Surya, Georges Bataille: la mort à l'oeuvre. Paris : Gallimard, 1992, p. 468.
} 
vida: vivendo no excesso, em meio a festas, orgias e sacrifícios, atividades nas quais se conduzia soberanamente, o homem consuma a si mesmo. A consciência da morte, da sexualidade e a exigência do trabalho introduzem as interdições, radicalizando a separação do homem em relação ao excesso e às condutas soberanas, que passam a ser reguladas pelo mundo homogêneo. O trabalho, afirma Bataille, é a consciência por meio da qual o homem abandonou a animalidade, entendida como excesso. ${ }^{38}$

A noção de sagrado é o signo com o qual a cultura generaliza o sentido profundo de suas interdições. Segundo Bataille, são as interdições que fundam o sagrado por circunscrever o campo da experiência-limite de onde irrompem as forças heterogêneas que constituem as condutas soberanas. Em relação ao mundo homogêneo, o sagrado representa a heterogeneidade e, enquanto tal, o vestígio de algo que forçosamente se fez ocultar sob a máscara conciliadora de um ideal de homem e de civilização. Deste modo, o mundo homogêneo se institui produzindo um sentido de cultura e redefinindo suas relações com a vida subordinadas às exigências da razão como finalidade e aos limites salvaguardados pela atividade produtiva. "Com a história pacificada, se dá a perda do sagrado". [...] "Sagrado era o mundo antes da operação escravizante do trabalho. Operação efetuada em busca de um fim" ${ }^{39}$

$\mathrm{Na}$ concepção nietzschiana, esse momento corresponde ao do homem dionisíaco. Celebrando o deus dilacerado e renascido, revivendo as formas que o pathos expressa nas relações do erotismo com a morte, os corpos se consumam numa experiência de continuidade, na base da qual emana, no dizer de Nietzsche, "uma vontade para o trágico", quando "visões e alucinações" [...] "se comunicavam a comunidades inteiras, a assembléias cultuais inteiras". ${ }^{40} \mathrm{Em}$ tais ocasiões do trágico, na ausência da angústia da morte gerada pela consciência do tempo, do projeto e do trabalho, a vida se associa a uma espécie de jogo no qual a violência e a consumação do corpo em práticas excessivas coloca o homem em linha direta com a morte, o que Ihe permite, nesta intensidade, afirmar a vida como vontade de potência. Isto se vincula a "tudo quanto há de mais terrível, maligno, enigmático, aniquilador e fatídico no mundo

\footnotetext{
${ }^{38}$ O.C. X, L'érotisme, p. 160.

${ }^{39}$ M.Surya, op., cit., p. 468.

${ }^{40}$ Nietzsche, op. cit., p. 17.
} 
da existência". ${ }^{41}$ Afinal, de onde mais teria surgido a tragédia? "Porventura do prazer, da força, da saúde transbordante, de uma plenitude demasiado grande?" 42

A história da cultura se confunde com a da neutralização e da expiação da violência, daquilo que Nietzsche associa à "sabedoria dionisíaca", na qual "aquele que por seu saber precipita a natureza do abismo da destruição há de experimentar também em si próprio a desintegração da natureza". ${ }^{43}$ Se há um saber na violência e na destruição, ele diz respeito a um modo de vida que reafirma as disposições da existência até na morte, constituindo um domínio em que a consciência, a razão e o trabalho se revelam inoperantes. É nesse ponto que a sabedoria dionisíaca de que fala Nietzsche e o não-saber da experiência que anuncia em Batalle as condutas soberanas se identificam com a afirmação do homem na consumação de si.

Para Nietzsche, o sentido trágico desaparece com a racionalidade e a predominância da consciência e do discurso enquanto dispositivos inibidores da violência e da intensidade próprias de uma relação imediata com a vida. Sócrates, no domínio da filosofia, e Eurípedes, no do teatro, são os artífices deste processo.

A razão do mundo homogêneo é uma conseqüência disto: ela ocupa o centro da vida humana, deixando os elementos heterogêneos na periferia. De um lado, o mundo puro da ordem, do trabalho organizado, do outro, o mundo impuro da violência, do erotismo e da morte.

Em O homem e o sagrado, de Roger Caillois, a polaridade do puro/impuro, configura-se do seguinte modo:

de um lado se agrupam e se ligam todas as potências positivas, "aquelas que conservam e fazem crescer a vida, que fornecem a saúde, a preeminência social, a coragem para a guerra e a excelência do trabalho", para retomar a definição de R. Hertz.

[...]

No outro extremo, acumulam-se as forças da morte e da destruição, as fontes das doenças, das desordens, das epidemias e dos crimes, tudo o que enfraquece, mina, corrompe, decompõe. ${ }^{44}$

\footnotetext{
${ }^{41}$ Id. ibid., p. 17.

42 ld. ibid., p. 17

43 Id. ibid., p. 65

${ }^{44}$ R. Caillois, op.cit., p.55.
} 
Tal cisão apresenta um aspecto normativo que regula a relação entre os dois mundos e os mantêm distanciados. Há ocasiões, porém, em que toda a violência do mundo heterogêneo se manifesta, liberando as forças transgressoras do excesso, ou forças "do mal", como são vistas pelo mundo homogêneo. Segundo Caillois,

onde a vida da sociedade e da natureza se encontra resumida na pessoa sagrada de um rei, a ocasião de sua morte desencadeia uma série de licenças rituais. Estas ganham então o aspecto que corresponde estritamente à catástrofe que sobrevém. O sacrilégio é de ordem social. Ele é perpetrado à custa da majestade, da hierarquia e do poder... ele nunca opôs a menor resistência ao frenesi popular: ele é considerado tão necessário quanto era a obediência ao defunto. Nas ilhas Sandwich, a multidão, ao saber da morte do rei, comete todos os atos vistos em tempos ordinários como criminosos: ela incendeia, pilha e mata, enquanto as mulheres são obrigadas a se prostituírem publicamente. ${ }^{45}$

O que dizer dessa passagem, reproduzida em $O$ erotismo por Bataille, senão que ela confirma a potência do excesso como um princípio gerador de violência, destruição e desordem? Eis também porque os dispositivos de controle e de verdade não são definitivos, mas provisórios, por mais sofisticados que hajam se tornado. Por vezes, como no exemplo acima descrito, acontecimentos de exceção tendem a ritualizar o que parece impossível de se regular socialmente. Entretanto, se estes fatos se repetem culturalmente, deixam de ser episódicos, para se afirmarem como ritos de exceção, nos quais o excesso desregrado e a violência desmedida se mostram em toda radicalidade. A este acontecimento, Bataille chama "transgressão ilimitada". É difícil limitar um tumulto quando ele é desencadeado. ${ }^{46}$ Mas, ainda assim, haveria um termo, pois a transgressão não se faz sem a ideia de sagrado: ela é, propriamente, a violação deste. Para Bataille, o sagrado é aquilo que estimula todo gesto transgressor. Deste modo renova-se a possibilidade do excesso: desautorizar uma lei, um saber, suspender uma ordem, abolir um discurso para fazer valer uma experiência-limite. Na transgressão ilimitada, este movimento parece apropriar-se de vez do sagrado, não para extingui-lo, mas para colar-se a ele como se esta espécie de jogo implicasse a conquista definitiva do ilimitado ou mesmo impossível. Com efeito, a experiência leva as forças heterogêneas ao paroxismo. Gastança exorbitante. Ação humana descontrolada no

\footnotetext{
${ }^{45}$ Id., ibid., pp. 152-153.

${ }^{46}$ O.C. X, L'érotisme, p. 68
} 
limiar da morte. Pletora de sangue, esperma e lágrimas aos borbotões. Potência do sim, potência do mais: haverá uma razão para o excesso a despeito da própria razão? 


\section{SOB O SIGNO DO GASTO}

\section{O fator econômico: produção, consumo e o "caráter trágico da despesa"}

Com isso nos colocamos inteiramente na perspectiva da "economia geral", invertendo a lógica do saber e do trabalho produtivo, na qual o homem se afirma pelo excesso sob o princípio do gasto. Trata-se de estabelecer, segundo Bataille, "o princípio de uma 'economia geral', em que a 'despesa' (o 'consumo') das riquezas é, em relação à produção, o objeto primeiro". ${ }^{47} \mathrm{~A}$ radicalidade dessa teoria exige "passar das perspectivas da economia restrita às da economia geral', logrando "uma mudança copernicana: a de colocar às avessas o pensamento - e a moral". ${ }^{48}$

O termo "economia geral" não somente marca uma oposição fundamental em relação à "economia restrita", entendida em sua concepção clássica de controle dos gastos com vistas à produção de bens e crescimento do capital, como, em última análise, reconfigura o domínio das relações econômicas, submetendo-as ao primado do gasto excessivo, ou do consumo sob o princípio da despesa. Com isso, a economia deixa de submeter-se a um dispositivo de controle, perdendo o fiel da balança, para ser entendida como atividade aberta às forças heterogêneas do excesso, da hybris. A contenção de gastos revela-se um artifício contrário à soberania do corpo que encontra no dispêndio sua razão de ser, consumando-se em pura perda. A economia geral consiste, portanto, na abertura irrestrita para a despesa, que soberanamente recusa 0 saber do trabalho produtivo em nome da experiência heterogênea do excesso, que não se subordina a nenhum saber, já que, para Bataille, não há dispêndio sem excesso, assim como todo excesso implica alguma forma de gasto.

O conjunto maior da economia geral sobrepõe-se ao menor, delimitado pelas prerrogativas do saber em nome da produção e da coisificação do homem. No extremo: a economia geral liberta o homem das amarras do mundo produtivo, o mundo homogêneo, para torná-lo soberano nas operações do gasto desenfreado e da

\footnotetext{
${ }_{48}^{47}$ O.C. VII, La part maudite, p. 19. [trad. bras. A parte maldita, p. 49]
}

${ }^{48}$ Id., ibid., p. 33. 
consumação de si. A razão restritiva do mundo do cálculo cede ao que se poderia chamar sem razão incalculável da potência do excesso. O saber do mundo homogêneo desmancha-se na voragem das forças heterogêneas do excesso sob o princípio do gasto. O que não se pode controlar, excesso, heterogeneidade, gastança, gaspiage, também não pode ser conhecido, nem servir à superestrutura enquanto forma e poder do saber constituído. Esse movimento comunica o "não-saber", a "sorte", o "impossível", termos-chave do pensamento de Bataille, por meio dos quais entende a sem razão da experiência, isto é, o excesso, impensável por definição, e a operação do gasto, soberana em sua singularidade. Como a economia geral excede a razão da economia restrita, no que esta apresenta como saber, discurso, lógica de produção, ela deverá ser pensada em consonância com aqueles termos heterodoxos, que, segundo Bataille, nos aproximam da experiência.

Eis porque, em seu pensamento, o gasto é uma operação soberana. Ainda que sua obra não possa ser descrita nos termos da economia geral, uma vez que o excesso extrapola toda explicação, todo conhecimento, como adverte Sasso, ${ }^{49}$ a despesa de energia no homem e no mundo representa um de seus aspectos essenciais. Isto se verifica na implicação imediata do gasto como efeito do excesso nas relações de força que se estabelecem entre os seres. No plano material, o princípio de despesa é o que ao mesmo tempo evidencia as forças heterogêneas do excesso e seus efeitos nos corpos. Qualquer que seja o efeito do excesso nos corpos ou o decorrente dos atos destes, tal princípio acarreta consumação, perda, ruína, morte. Daí o caráter negativo que as atividades marcadas pelo gasto adquirem na cultura.

As exigências de gasto e de consumo desenfreado decorrem dos acontecimentos da experiência, como no erotismo, no êxtase, na poesia, atividades que não se fazem sem uma relação direta com a consumação.

A morte como "aprovação da vida", na formulação de Bataille, não deixa de ser afirmação da vontade de excesso e consumação de si: se a vida se mostra potente, se as relações entre os seres e coisas se intensificam em função dessa potencialização, é porque o excesso na vida material está associado ao princípio de gasto. $\mathrm{Na}$ vida material, mas também nas instâncias abertas pela subjetividade, nas quais a

\footnotetext{
${ }^{49}$ R. Sasso, Georges Bataille: le système du non-savoir, op. cit., p. 56.
} 
experiência de perda e de subversão da consciência são consumações de si no decurso de acontecimentos, como o erotismo, o êxtase, a loucura, a criação artística. Nesta, o gasto como efeito da operação soberana se manifesta não apenas na vida do sujeito, mas também na própria atividade inoperante, a exemplo da poesia, que, antes de tudo, para Bataille, é "sacrifício de palavras". Assim, ainda que o corpo seja o principal nas forças heterogêneas do excesso, não é difícil constatar que os efeitos do gasto se fazem sentir dentro e fora, isto é, no mundo dos seres em geral, mas também nas atividades em que a produção se suspende e as operações dispendiosas são soberanas, na inoperância, por meio da experiência heterogênea.

Veremos mais tarde a poesia enquanto operação soberana, dada sua importância na lógica da transgressão entendida por Bataille como fundamento de sua própria obra.

Por mais que o mundo homogêneo restrinja as relações econômicas a um campo de operações determinadas visando ao controle das despesas sob o princípio de racionalidade, a exigência do gasto e, no limite, a do gasto desenfreado, são determinantes enquanto tendência subterrânea, contrária ao domínio da produção. Com isso, tais disposições se tornam inapeláveis na esfera do consumo, que passa a sofrer o impacto das forças heterogêneas do excesso. Este fator recorrente, determinante na conduta dos corpos e na relação entre seres e linguagens (daí o sentido geral dessa economia), se radicaliza nas experiências heterogêneas do erotismo, do sacrifício, da efusão extática, as quais, como se viu, constituem o espaço próprio da inoperância sob o princípio do gasto e respondem diretamente ao excesso.

Para Bataille, portanto, a atividade humana não se limita à produção e à conservação: o consumo é o dado fundamental minimizado pela economia clássica e se distingue de dois modos, um consumo que minimamente permite a conservação da vida e o prosseguimento da atividade produtiva, e outro decorrente das atividades de despesa improdutiva, como o luxo, os enterros, as guerras, os cultos, a edificação de monumentos, os jogos, os espetáculos, as artes, a atividade sexual perversa. ${ }^{50}$ Este modo de consumir é próprio das formas improdutivas caracterizadas por uma ênfase na

${ }^{50}$ O.C. I, La notion de dépense, p. 305. 
perda, devendo ser a maior possível para que a atividade adquira seu "verdadeiro sentido". 51

Eis a condição para que o princípio de despesa desautorize o saber da produção e a produção do saber e afirme a vida como vontade de excesso. Deste modo, o princípio da utilidade clássica, fundamento da "economia restrita", se revela insuficiente. Mas insuficiente para quê? Qualquer resposta a esta questão, construída à luz do pensamento de Bataille, lança o intérprete praticamente na encruzilhada das motivações principais de sua obra: por um lado, a insuficiência da vida, o caráter regulador das proibições e dos limites, por outro, o desejo insaciável do corpo, a exigência de gasto, a transgressão e, em conseqüência, a crise do sujeito, sentida como angústia, sofrimento, no mundo homogêneo gerando como resposta a experiência heterogênea do excesso.

Mas qual seria este aspecto que nos faz "reconhecer na prodigalidade o único meio de não decair..." ?52

Há em Bataille esse manifesto a favor do corpo, invariavelmente posto numa via de excesso, constituindo a linha de força que atravessa sua obra e a faz vibrar, colocando no limite a própria experiência do pensamento e da linguagem por meio da operação soberana da escrita. Eis seu empenho em situar a problemática econômica numa perspectiva geral que exacerba as prerrogativas do corpo sob o primado da despesa. Nesse sentido, o consumo desenfreado expõe a fenda, fêlure, aberta pelo excesso no sujeito e que não por acaso "o mundo presente, pouco preocupado com a verdade" 53 , tem dificuldade em admitir. Quando se atenta para as exigências da prodigalidade e da conseqüente demanda de excesso e de gasto que, no limite, caracterizam as ações dessa espécie, o mundo homogêneo só o faz "pela metade e timidamente", como até mesmo em Mauss, sem "nenhuma resposta eficaz" 54.

Assim, a advertência de Bataille aponta para o ápice da economia geral que está na base de todo excesso e de toda demanda de gasto: o caráter trágico da despesa. Eis o que não se pode negligenciar e que constitui o modus operandi da economia

\footnotetext{
${ }^{51}$ Id., ibid., p. 305.

52 Id., ibid.,"Notas", § 10, p. 666.

${ }^{5}$ ld., ibid.

54 Id., ibid.
} 
geral. O caráter trágico da despesa configura o núcleo irradiante do homem que a cultura busca ofuscar. Tal caráter pode se constituir na morte da própria cultura:

\begin{abstract}
É necessário reservar a exigência desmesurada deste princípio [de despesa], que não somente conduz a perdas de trabalho consideráveis, mas também a perdas de vidas humanas. Seria inútil focar nas condições atuais o problema paradoxal da despesa caso se queira dissimular seu caráter trágico. O mundo humano está longe de ser tão simples quanto a economia ingênua representa: onde quer que o homem se encontre, existe uma necessidade surda de hecatombe. A preservação da vida conta pouco quando as forças de extravasamento que comandam a irradiação estelar se apoderam explosivamente dos seres humanos. ${ }^{55}$
\end{abstract}

Em suma: se a exigência de despesa é desmesurada, seu caráter trágico ressurge, prova de que a demanda pelo gasto exorbitante está intimamente associada a toda experiência que coloca o homem na via de excesso. O caráter trágico é, portanto, o sentido imanente da economia geral proposta por Bataille. Seu principal argumento não se baseia na contenção de gasto ou controle de despesa, para assegurar o capital como um bem visando à saúde do mundo homogêneo, mas numa necessidade trágica cuja sem razão exige gasto a todo custo, nem que se sacrifiquem vidas humanas. $A$ economia geral concebe o homem em seu extremo, em sua "necessidade surda de hecatombe", de modo que todo consumo, representando gasto sem reservas, despesa em pura perda, se liga, em última instância, ao que é trágico, ou seja, a "tudo quanto há de mais terrível, maligno, enigmático, aniquilador e fatídico no mundo da existência", para lembrar as palavras de Nietzsche. ${ }^{56}$

Enquanto efeito da experiência heterogênea decorrente da exposição do corpo às forças excessivas do erotismo, do sacrifício, da morte, o trágico se apresenta na economia geral, de modo que as grandes crises do homem, os acontecimentos nos quais ele vivencia uma experiência-limite representam o primordial da vida. É por isso que as operações de gasto são soberanas em Bataille, já que estão relacionadas com toda vontade de excesso, que, por sua vez, acarreta hecatombes de energia.

A perda, a propósito, é a condição do sujeito na experiência, na medida em que é dramatizada, sendo o acontecimento, tal a morte do sujeito, ou a experiência de sua

\footnotetext{
${ }^{55}$ Id., ibid., pp. 666-667.

56 Nietzsche, O nascimento da tragédia ou helenismo e pessimismo. São Paulo: Companhia das letras, 1999 , p. 17.
} 
dissolução, objeto de uma operação soberana de gasto. Sem esta dramatização, não há experiência propriamente, já que esta se dá na esfera da subjetividade. Do mesmo modo, sem perda, não há o que dramatizar, nem como trazer o trágico: "a experiência seria inacessível se não soubéssemos dramatizar", afirma Bataille. ${ }^{57}$ Por isso a perda corresponde à imagem do sujeito que se consuma na experiência: "o objeto na experiência é primeiramente a projeção de uma perda de si dramática" ${ }^{58}$

Assim, toda teoria, e não apenas a econômica, se quiser pautar-se pelo essencial, deverá levar em conta o caráter trágico que se encontra na base da cultura à maneira de uma ferida que jamais se fecha totalmente, expondo a verdade recalcada do mundo homogêneo.

Para Bataille, há que se considerar a exigência de gasto como contrapartida do sistema produtivo, pois nem toda energia pode ser consumida, dando margem a um excedente que não pode ser aproveitado para o crescimento. Ele se torna, com efeito, "negatividade sem emprego", espécie de excrescência do processo produtivo, constituindo a "conduta soberana" oposta ao homem-coisa, revertendo o quantum de energia inteiramente para as atividades heterogêneas: a pura perda.

O mundo homogêneo, no entanto, aposta na racionalidade produtiva por meio da qual organiza e regula a estrutura social numa economia dependente do equilíbrio entre produção e consumo. Este modelo encontra em Benjamin Franklin exemplo dessa retórica:

Lembra-te que tempo é dinheiro; aquele que com seu trabalho pode ganhar dez xelins ao dia e vagabundeia metade do dia, ou fica deitado em seu quarto, não deve, mesmo que gaste apenas seis pence para se divertir, contabilizar só essa despesa; na verdade gastou, ou melhor, jogou fora, cinco xelins a mais. ${ }^{59}$

Eis um ideal de vida forjado para um mundo devidamente regido por medidas de contenção econômica e produtividade sem trégua, um espírito de homem sóbrio em sua conduta, já que a esfera do economos diz respeito à organização própria do lar, em primeira instância, como reflexo da boa conduta, atendo-se ao controle de despesa e à

\footnotetext{
${ }^{57}$ O.C. V, L'expérience intérieure, p. 136.

${ }^{5}$ Id., ibid., p. 137.

${ }^{59}$ B. Franklin.Ver. M. Weber, A ética protestante e o espírito do capitalismo. São Paulo: Cia das Letras, 2008, pp. 4243.
} 
extensão regulada no mundo. Fazendo de seu lar o espaço preliminar da contenção econômica, o homem amplia este paradigma para o bem comum da sociedade. $A$ economia, cujas leis regem as relações dos indivíduos nessa esfera, deve refletir a moral dos princípios praticados pelo homem no âmbito doméstico.

Por isso mesmo, "o ódio da despesa é a razão de ser e a justificação da burguesia: ele é ao mesmo tempo o princípio de sua pavorosa hipocrisia”. 60 Com efeito, Bataille faz observar um sintoma do antigo potlatch, no qual já estão dados os componentes básicos da luta de classes moderna:

\begin{abstract}
No potlatch, o homem rico distribui produtos que Ihe são fornecidos por outros homens miseráveis. Procura elevar-se acima de um rival rico como ele, mas o último grau de elevação que se tem em vista não tem finalidade mais necessária do que afastá-lo ainda mais da natureza dos homens miseráveis. Assim, a despesa, embora seja uma função social, desemboca imediatamente em um ato agonístico de separação, de aparência anti-social. O homem rico consome a perda do homem pobre, criando para este uma categoria de desgraça e de abjeção que abre o caminho para a escravidão. Ora, é evidente que, da herança do mundo suntuário antigo indefinidamente transmitida, o mundo moderno recebeu em partilha essa categoria, atualmente reservada aos proletários. $^{61}$
\end{abstract}

É por esse prisma da economia geral que Bataille vê as relações sociais, sobretudo as forças que apartam a classe trabalhadora das despesas suntuárias. Se estas dizem respeito ao primordial no homem, a lógica produtiva do mundo homogêneo baseada na economia restrita revela-se absurda, já que a exigência de gasto é imanente ao corpo e este não hesita em satisfazê-la quando a estrutura social o permite, ainda que para isto se condene à escravidão do trabalho a parcela da sociedade alijada dos meios de produção. Ora, segundo Bataille, a sociedade burguesa não aceita sem protestar uma divisão que parece destrutiva do homem, mas é incapaz de levar essa resistência mais longe do que a negação teórica: "O fim da atividade operária é produzir para viver, mas o da atividade patronal é produzir para destinar os produtores operários a uma horrível desgraça". 62

\footnotetext{
${ }^{60}$ O.C. I, La notion de dépense, p. 314.

${ }^{61}$ Id., ibid., pp. 314-315.

62 Id., ibid., p. 315.
} 
Deste modo, no âmbito de suas relações de força, o mundo homogêneo não faz senão justificar uma estrutura social desigual e perversa que viabiliza a despesa de uns e limita o consumo de outros a níveis muito inferiores. É certo que mesmo os oprimidos encontram meios de consumar sua demanda de excesso, desviando-se do trabalho produtivo, tornando-se inoperantes, mas relegados à condição de párias. Por mais opressivas que se apresentam as condições impostas pelo trabalho em oposição às despesas suntuárias, a vontade de excesso permanece como algo a ser satisfeito a todo custo, sendo aquilo que no homem conduz ao ápice da consumação, uma vez que, para Bataille, a falta, esse estado de insuficiência permanente, define todos os seres.

A perspectiva de consumo aberta pela economia geral abarca todos os níveis de despesa suntuária, arrancando o homem da categoria de coisa imposta pelo mundo homogêneo e dando vazão às experiências de consumação do sujeito. Mas isto só é possível com a inoperância nas ocasiões em que as exigências de gasto forçam passagem no social por meio das forças heterogêneas, as quais, como quanta de energia desviada da atividade produtiva, tornam-se negatividade sem emprego. O que confere à experiência este caráter de negação é justamente aquilo que nela recusa o trabalho, afirmando a inoperância. É nesta sem razão que consistem as demandas pelo gasto e vontade de excesso. Inoperante é a negatividade sem emprego que desvia o corpo do trabalho e dispõe o sujeito numa via de consumação sem reservas.

Marx afirma ser "toda produção uma apropriação da natureza pelo indivíduo, no interior e por meio de uma determinada forma de sociedade". ${ }^{63}$ Apropriar-se de algo é, para a razão capitalista, convertê-lo em elemento útil para a economia, visando à acumulação. Numa primeira instância, este sistema procura adequar toda necessidade humana a esta lógica de produção, criando "objetos que correspondem às necessidades (Bedürfnissen)". ${ }^{64}$ Mas este ajuste de necessidades ao sistema de produção inviabiliza a margem para o livre gozo da subjetividade que a inoperância favorece, convertendo o homem num objeto funcional do mundo homogêneo, já que, na

\footnotetext{
${ }^{63}$ K. Marx, "Para a crítica da economia política", in Os pensadores. São Paulo: Abril cultural, 1974, p. 112.

64 ld., ibid., p. 113.
} 
produção, segundo Marx, "a pessoa se objetiva; no consumo, a coisa se subjetiva". ${ }^{65}$ Este homem-coisa, se tem garantidas as necessidades básicas que no limite the asseguram a subsistência, não encontra os meios de satisfazer demandas para maiores gastos de energia, cuja exigência é alheia ao sistema produtivo. No mundo homogêneo, toda demanda por consumo é regulada pela medida exata da produção; por essa lógica econômica, produção e consumo são faces complementares do mesmo processo homogeneizante.

No entanto, adverte Marx: "esta determinação do consumo produtivo só é estabelecida para reparar o consumo idêntico à produção, do consumo propriamente dito, concebido, ao contrário, como antítese destruidora da produção". ${ }^{66}$ Nesse breve esquema das condições determinantes para o equilíbrio entre produção e consumo idealizadas pelo mundo homogêneo vislumbra-se o viés aberto pela economia geral em que a negatividade sem emprego se torna o princípio desencadeador das operações de gasto e consumação do sujeito.

A exploração da força de trabalho na mais-valia relativa é evidenciada pelo processo produtivo subjugado pelo capital que "instaura um mundo perverso enfeitiçado". ${ }^{67} \mathrm{O}$ próprio sistema introduz um princípio de irregularidade fazendo irromper as forças heterogêneas do excesso e predispondo à consumação sem reservas os corpos beneficiados pelo capital, enquanto a outra parte da sociedade, ocupada com o trabalho, se acha impedida de consumir na mesma proporção, e vê inviabilizadas as operações soberanas do gasto.

$\mathrm{Na}$ análise de Marx, tal irrupção é entendida como a antítese pelo sistema produtivo, pois a razão do capital degenera o consumo em gasto desenfreado. Deste modo, o capitalismo pode ser visto como a face cínica do mundo homogêneo, já que dispõe dos modos de produção, apregoa o controle dos gastos que a economia restrita prescreve para a funcionalidade do sistema e ao mesmo tempo gera no social uma necessidade imperiosa de consumo regulada por uma economia excludente. Introduzindo na razão homogênea do trabalho produtivo este princípio de

\footnotetext{
${ }^{65}$ Id., ibid., pp. 113-114.

66 ld., ibid., p. 115.

${ }^{67}$ Expressão utilizada por Deleuze e Guattari . Ver G. Deleuze e F. Guattari, O anti-édipo. Rio de Janeiro: Imago, 1976, p. 25.
} 
irregularidade, o capitalismo expõe as fissuras do mundo homogêneo, revelando sua face heterogênea como a parte oculta e maldita.

\title{
Capital e libido: a face perversa do mundo homogêneo
}

Bataille remete o leitor a um passado remoto no qual o trabalho funda a ideia de homem em oposição à violência que excede a razão. Do ponto de vista do mundo homogêneo, a violência, sob o princípio do excesso, torna o homem acéfalo. ${ }^{68}$ Por isto, "desde os tempos mais remotos, o trabalho introduziu uma trégua, em favor da qual o homem deixava de responder ao impulso imediato que a violência do desejo determinava". ${ }^{69}$ Esta disposição pelo trabalho afasta o homem da violência e dos grandes gastos de energia.

\begin{abstract}
O trabalho exige uma conduta na qual o cálculo de esforço, ligado à eficácia produtiva, é constante. Ele exige uma conduta razoável, na qual os movimentos tumultuosos que se liberam na festa e, geralmente, no jogo, não são admissíveis. Se não pudéssemos frear estes movimentos, não seríamos capazes de trabalhar; mas o trabalho introduz justamente a razão de contêlos. 70
\end{abstract}

Assim, as grandes despesas exigidas pelas festas, pelos jogos e orgias são refreadas em nome da atividade produtiva e seu empenho em livrar o corpo (e a razão) do excesso. Apesar disto,

por mais razoáveis que tenhamos nos tornado, uma violência que não é nada além da violência natural pode nos dominar novamente - que é a violência de um ser racional, que tentou obedecer, mas sucumbe ao movimento que em si próprio não pode reduzir à razão. ${ }^{71}$

Este argumento, como se viu, ressalta o caráter reincidente da violência, a qual não pode ser erradicada por se encontrar na base da própria razão. Para todo efeito, a ocupação com o trabalho não garante à racionalidade total controle sobre as forças heterogêneas do excesso, e o trágico retorna com as despesas suntuárias,

\footnotetext{
${ }^{68}$ A noção será desenvolvida mais adiante, no tópico "acefalia e morte".

${ }^{69}$ ld., ibid., p. 44.

${ }^{70}$ Id., ibid., p. 44.

${ }^{71}$ L'érotisme, op., cit., p. 43.
} 
invariavelmente acompanhadas de violência social. A heterogeneidade, no fundo, é o que constitui a razão do mundo homogêneo. Mas a razão se estrutura em torno daquilo que não pode controlar e vê como exterioridade impura. Por isso, do ponto de vista do saber, o caráter heterogêneo da violência é contrário a toda objetivação: o que não se pode isolar como objeto não é controlável racionalmente. No entanto, através da razão, o mundo homogêneo legitima a violência que the interessa praticar, ou seja, o excesso que a sem razão da heterogeneidade libera, lembrando que, para Bataille, todo excesso assinala também seu limite. Nesse sentido, por meio da violência que lhe é imamente, o mundo homogêneo excede a si mesmo estabelecendo limites para a própria violência, a qual, no entanto, como efeito desencadeado pelo excesso, se consuma como impulso ilimitado, ainda que a consumação, em si mesma, só aconteça enquanto experiêncialimite. Por este motivo, Bataille afirma que as interdições, no fundo, são irracionais, ${ }^{72}$ pois a razão não pode, com base numa lei, limitar o excesso, que the é exterior Deste modo, o mundo homogêneo despende enorme quantidade de energia para manter-se mediante os mais diversos dispositivos institucionais (ciência, religião, direito) que adaptam a cultura a um ideal de homem. Ora, o propósito de Bataille é sempre demonstrar que o homem vive em meio à vontade de excesso e às exigências de gasto, as quais, afinal, surgem "na medida em que a violência suplanta a razão". ${ }^{73}$

Evoca-se, aqui, a ideia de Lyotard segundo a qual não se pode separar o que é "de capital (ou de economia política) e o que é de subversão (ou de economia libidinal) ${ }^{74}$ entendendo esta última como vetor de heterogeneidade. Se no capitalismo o trabalhador é reduzido a uma coisa, isto se deve a essa máquina de gozo na qual a usura garante a alguns as trocas libidinais enquanto exclui outros deste domínio. Canalizando a força dos explorados na atividade produtiva, o capitalismo garante àqueles que exploram enormes gastos libidinais. É a sua face perversa.

Deste modo, o sistema capitalista não se mantém pelo equilíbrio entre produção e consumo, já que a produção implica o consumo, pois demanda grandes investimentos e gastos de energia. $\mathrm{O}$ capitalismo se mantém por excedente, explorando o trabalho alheio. É na apropriação da força do trabalho que a máquina capitalista vai produzir a

\footnotetext{
72 Id., ibid., p.40.

${ }^{73}$ Id., ibid., p. 44.

74 J.F. Lyotard, L'économie libidinale. Paris : Minuit, 1974, p.133.
} 
mais-valia como lucro no processo produtivo. Este "sobreproduto" de Marx, corresponde, em Bataille, ao "homem rico [que] consome a perda do homem pobre criando para este uma categoria de desgraça e de abjeção que abre o caminho para a escravidão". ${ }^{75}$

O caráter perverso do capital irrompe desta equação absurda: aqueles que mais despendem energia na produção são os que menos participam na gastança, pois "o tumulto suntuário vivo perdeu-se no desencadeamento inaudito da luta de classes". ${ }^{76}$

Como se vê, para Bataille, o fundamental desta inversão no significado geral da economia, é o dispêndio: "o princípio de uma 'economia geral', em que a 'despesa' (o 'consumo') das riquezas é, em relação à produção, o objeto primeiro". 77 O mundo homogêneo, produzindo seu excedente, acumulando-o no sistema de produção, elimina o dispêndio como negatividade sem emprego: inoperância que se converte em força heterogênea nas operações soberanas do gasto. "De fato, do modo mais universal, isoladamente ou em grupo, os homens encontram-se constantemente empenhados em processos de despesa" ${ }^{78} \mathrm{~A}$ insuficiência, a falta, a "vontade de ápice", como diz Bataille, são inflexíveis. Afinal, "os homens asseguram sua subsistência ou evitam o sofrimento, não porque essas funções determinem por elas mesmas um resultado suficiente, mas para ter acesso à função insubordinada da despesa livre". 79

Os capitalistas satisfazem suas demandas de gasto à custa do trabalho alheio, conservando, assim, por essa lógica da produção e pela perversão do capital, a estrutura econômica do mundo homogêneo.

Para Deleuze e Guattari, no entanto, cuja análise se detém particularmente no capitalismo, a produção é imediatamente consumo e o consumo, produção. É o desejo; seu funcionamento pode ser traduzido em termos de uma dinâmica multiforme e onipresente de "máquinas desejantes", que produzem conectadas umas às outras. Aqui, "tudo é produção: produção de produções, de ações e de paixões; produções de registros, de distribuições e de marcações; produções de consumo, de volúpias, de

\footnotetext{
${ }^{75}$ O.C., I, La notion de dépense, p. 315

${ }^{76}$ Id., ibid., p. 314.

${ }^{77}$ O.C., VII, La part maudite, p. 19.

${ }^{78}$ O.C., I, La notion de dépense, p. 319

79 Id., ibid., p. 320.
} 
angústias e de dores" ${ }^{80} \mathrm{O}$ fator heterogêneo opera nesta análise, denominado "corpo sem órgãos", expressão tirada de Artaud. No sistema capitalista, o corpo sem órgãos é o outro nome da inoperância ${ }^{81} \mathrm{e}$ o improdutivo é figura recorrente nas análises da produção. Não há como evitá-lo na medida em que ele constitui a parte maldita das relações entre a produção e o consumo.

Para Deleuze e Guattari, a figura do improdutivo implode a subjetividade no excesso, desaguando na sem razão. Em Bataille, a inoperância das forças heterogêneas do excesso faz aflorar a parte maldita; esta sem razão constitui a experiência à margem do sistema de produção, exigindo consumação de si; a experiência é um fenômeno imprevisível, o qual, dispondo a inoperância sob o primado do gasto, torna a subjetividade gozosa. Nisso, o que é recalcado no homem, seu aspecto subterrâneo, heterogêneo, emerge na experiência como resposta às exigências de excesso e às demandas de gasto.

Toda ação excessiva implica o dispêndio, assim como todo gasto tem relação com o excesso, que, por definição, como diz Bataille, sempre excede a si mesmo. Deste modo, quanto maior a vontade de excesso no social, tanto maior a exigência de gasto. A inoperância favorece o excesso, que na soberania da experiência satisfaz as necessidades que não comportam o mundo do trabalho produtivo. As operações soberanas do gasto constituem, assim, a parte maldita, que o mundo homogêneo recalca ou rejeita.

\section{A poesia como atividade improdutiva}

Bataille destaca a literatura e o teatro como despesas simbólicas, entendidas em sua "forma maior". Ambas as artes "provocam a angústia e o horror através de representações simbólicas da perda trágica (desgraça ou morte)". 82 Para todo efeito, nos termos da economia geral, a despesa simbólica constitui o punctum saliens da poesia:

\footnotetext{
${ }^{80}$ G. Deleuze e F. Guattari, op. cit., p. 18

${ }^{81}$ Id., ibid., p. 23.

${ }^{82}$ O.C., I, La notion de dépense, p. 307.
} 
O termo poesia, que se aplica às formas menos degradadas, menos intelectualizadas da expressão de um estado de perda, pode ser considerado como sinônimo de despesa: significa, com efeito, do modo mais preciso, criação por meio da perda. Seu sentido, portanto, é vizinho do de sacrifício. É verdade que o nome poesia só pode ser aplicado de modo apropriado a um resíduo extremamente raro disso que vulgarmente ele serve para designar, e que por falta de redução prévia as piores confusões podem surgir; ora, é impossível, numa primeira e rápida exposição, falar dos limites infinitamente variáveis entre formações subsidiárias e o elemento residual da poesia. É mais fácil indicar que, para os raros seres humanos que dispõem desse elemento, a despesa poética deixa de ser simbólica em suas conseqüências: assim, em certa medida, a função de representação empenha a própria vida daquele que a assume. Ela o consagra às mais falazes formas de atividade, à miséria, ao desespero, à persecução de sombras inconsistentes que nada podem dar além da vertigem ou do furor. Freqüentemente só pode dispor das palavras para sua própria perda, é obrigado a escolher entre um destino que faz de um homem um rejeitado, tão profundamente separado da sociedade quanto os dejetos da vida aparente, e uma renúncia cujo preço é uma atividade medíocre, subordinada a necessidades vulgares e superficiais. ${ }^{83}$

No âmbito da economia geral, a poesia é a inscrição da despesa suntuária no plano simbólico, por implicar sacrifício de palavras, perda de linguagem na operação, o que corresponde ao que Bataille chama de parte maldita. Neste potlatch simbólico, o poeta é o improdutivo por excelência, já que a poesia, em sua experiência, exige uma conduta soberana que leva o poeta à consumação de si. O sacrifício das palavras é, assim, a forma simbólica da despesa de linguagem e da consumação do sujeito. Esta dupla operação se faz sob o impacto de uma terceira: a poesia coloca o discurso em crise porquanto sua linguagem excede o discurso do saber e o saber do discurso. Excesso de linguagem, a poesia não corresponde aos discursos do saber e do poder (ciência, filosofia, direito), nem às linguagens da comunicação (ideologia, senso comum). Nas palavras de Jean Cocteau: "A poesia é uma língua à parte que os poetas podem falar sem medo de ser entendidos, pois os povos têm o costume de tomar esta língua como uma maneira de empregar a deles". 84

Para Bataille, a poesia é por isso mesmo uma "língua à parte", considerada maldita pelo mundo homogêneo. A atividade poética é, por excelência, a via simbólica da heterogeneidade.

\footnotetext{
${ }^{83}$ Id., ibid., p. 307.

84 J. Cocteau. "Clair-obscure", in Poèmes. Paris: Rocher, 1984, p. 65.
} 
A vizinhança da poesia e do sacrifício está na conservação do resíduo da prática sacrificial. Este elemento residual torna a poesia "sinônimo de despesa", "criação por meio de perda" Em conseqüência, essa conduta soberana, desviando o poeta do trabalho produtivo, leva-o "à miséria, ao desespero", na consumação de si.

A singularidade da poesia, para Bataille, está em ser um potlatch simbólico, o que revela seu caráter trágico, considerando-se que a despesa simbólica pode ser a outra via da economia geral. Nesse sentido, a efusão poética é consumação no campo simbólico, na linguagem, compossível com a vontade de excesso e com a exigência de gasto que caracterizam a economia geral, e a soberania como tal.

A poesia não se constitui apenas como um campo de exceção no qual as forças heterogêneas se afirmam no excesso da linguagem contra o saber instituído, mas também como operação soberana. Com isso, a atividade improdutiva da poesia se revela um modus operandi da economia geral, tornando o campo simbólico da linguagem uma via de consumação do sujeito e do saber instituído. "O que nós seríamos sem a linguagem? Ela nos fez o que somos. Só ela revela, no limite, o momento soberano em que não há mais curso. Mas, no fim, aquele que fala confessa sua impotência". ${ }^{85}$ É o poder e a falência da linguagem. Em seu momento soberano, ela se consuma no silêncio. Não será estranho afirmar, na esteira do pensamento de Bataille, que a despesa simbólica é prova de não haver saída para o homem que procura a todo custo ocultar a violência com o discurso e o saber. Nenhum tribunal da razão pode garantir à espécie humana uma alternativa, nem ao menos honrosa, à consumação de si na ruína e na morte. No extremo, a conduta soberana da poesia implica aceleração e intensidade da própria existência, sob o princípio do excesso, lançando o corpo improdutivo na marginalidade. O poder mediante o qual a linguagem poética excede o discurso do saber é também seu limite. A consumação de si é, ao mesmo tempo, afirmação da vida em ruína e negação dos sentidos da razão, fechando as portas para as instituições do discurso (a religião, o direito, a ciência), descontinuando a linguagem, que finalmente é excedida, soterrada no absoluto silêncio da morte. A poesia, para Bataille, importa, não pelos sentidos que expressa, pelo saber que afirma, apesar do saber, mas por ser soberana no campo simbólico, o mesmo

\footnotetext{
${ }^{85}$ L'érotisme, op., cit., p. 270.
} 
espaço ocupado pelo discurso do saber, o qual, por fim é excedido pela consumação do sujeito e da própria linguagem. Ela consuma o excedente do mundo homogêneo, de sua produtividade mesma, aliás, excedendo o discurso para, como diz Bataille, chegar "ao mesmo ponto do erotismo", e ser a "linguagem do impossível". Poesia é exuberância, exatamente no ponto em que a linguagem responde, soberanamente, à imperiosa vontade de excesso. Enquanto vigora e se faz vibrar na intensidade dos signos, excedendo os sentidos do discurso e o discurso como sentido, ela se faz contínua. Poesia, diz Bataille, evocando Rimbaud, é continuidade: "C'est la mer allée avec le soleil". ${ }^{86}$ Pela poesia, enquanto atividade improdutiva de despesa chega-se à imagem solar. Na obra de Bataille, o sol é justamente a figura que representa no mundo dos seres o princípio do excesso gerador.

\title{
O paradigma solar
}

\begin{abstract}
A fonte e a essência de nossa riqueza são fornecidas na irradiação do sol, que dispensa a energia - a riqueza - sem contrapartida. O sol dá sem nunca receber: os homens sentiram isso muito antes de a astrofísica ter medido essa incessante prodigalidade. [...] Torna-se necessário, a essa altura, assinalar uma dupla origem dos julgamentos morais. Outrora, dava-se valor à glória improdutiva, ao passo que em nossos dias ele é relacionado diretamente com a produção: a aquisição da energia tem precedência sobre a despesa. A própria glória é justificada pelas conseqüências de um fato glorioso na esfera da utilidade. Contudo, obnubilado pelo julgamento prático - e pela moral cristã - o sentimento arcaico está vivo: encontra-se, em particular, no protesto romântico oposto ao mundo burguês; ele só perde inteiramente seus direitos nas concepções clássicas da economia. ${ }^{87}$
\end{abstract}

Há dois tipos de despesa: o primeiro revela um sentimento arcaico de adesão ao princípio de gasto, o qual, apesar de não mais gozar como antes da "glória improdutiva", ainda "está vivo"; o segundo vincula-se ao sentido da utilidade, desembocando no primado da aquisição de energia sobre a despesa e que representa, propriamente, uma tendência da racionalidade ocidental em valorizar a produção como

\footnotetext{
${ }^{86}$ Id., ibid., p.271.

${ }^{87}$ O.C., VII, La part maudite, pp. 35-36.
} 
a verdade das concepções clássicas da economia. Este segundo tipo é o que prevaleceu.

Isso porque o homem sobre o planeta é apenas, de modo indireto e subsidiário,
uma resposta ao problema do crescimento. Sem dúvida pelo trabalho e pelas
técnicas, ele se tornou sua extensão possível, para além dos limites recebidos.
Entretanto, assim com o herbívoro é, em relação à planta, um luxo-o carnívoro
em relação ao herbívoro -, o homem, de todos os seres vivos, é o mais apto a
consumir, intensamente, luxuosamente, o excedente de energia que a pressão
da vida propõe a incandescências conformes à origem solar de seu
movimento. ${ }^{88}$

Deste modo, como o "sentimento arcaico está vivo", o primeiro tipo de despesa se afirma com intensidade nos acontecimentos heterogêneos da experiência. Trata-se de algo imanente ao corpo, numa comunidade de corpos em excesso.

Tendo o sol como paradigma, a teoria do gasto em Bataille encontra seu fundamento num plano cósmico, salientando o sentido da vida como consumação. Ao consumarem seus bens e a si próprios, mergulhados na imanência por meio das condutas soberanas da experiência, os homens reproduzem no âmbito de suas relações o modelo transcendente da despesa solar. Nele, o sol representa a potência do excesso gerador, proporcionando à vida "seu desenvolvimento exuberante": fonte de energia, exuberante em si mesmo, o sol "dá sem nunca receber". Como seu crescimento chega ao limite e, não podendo mais se expandir, a vida na terra se beneficia com o excedente desta superabundância.

Considere-se, também, a energia concentrada no interior da terra, onde, em seu núcleo, a pressão e as temperaturas são absurdamente altas, ou seja: o excesso gerador também opera a partir do núcleo terrestre. A geologia reitera a importância dessas forças internas na criação da vida, devido a um equilíbrio entre a energia do sol do lado externo e a energia proveniente das profundezas da terra. Isso explica porque, fora desse equilíbrio, a relação da vida com a plena potência do excesso seria impossível: no mundo dos seres há sempre um limite na relação com a potência. Do ponto de vista geológico, porém, a história da terra é feita de excessos: grandes inundações e todas as intervenções da profundidade por meio de rochas ígneas,

\footnotetext{
${ }^{88}$ Id., ibid., p. 43. [trad. bras. A parte maldita, p. 75.
} 
vulcânicas, plutônicas. ${ }^{89}$ A atividade vulcânica é um sinal visível dessa energia excedente do núcleo do planeta entendido como princípio gerador.

Imagens de fenômenos naturais descritos como figuras de excesso são freqüentes em Bataille: "o globo terrestre ficou enorme como um crânio calvo no meio do qual o olho que se abre no vazio é ao mesmo tempo vulcânico e lacustre". ${ }^{90}$ Esta figura antropomórfica da natureza exorbita o olhar designando a despesa. Não é outro o olhar soberano do êxtase, voltado para a consumação de si. Signos do excedente e do gasto, sol, ânus, olho, associam-se em Bataille:

Eu me representava com o olho no topo do crânio como um horrível vulcão em erupção, justamente por este caráter ambíguo e cômico ligado ao traseiro e suas excreções. Ora, o olho é sem dúvida o símbolo do sol ofuscante, e aquele que imaginei no topo de meu crânio estava necessariamente em brasa e fora consagrado à contemplação do sol no summum de seu clarão. ${ }^{91}$

A despesa opera a linguagem, evidenciando a soberania: o olho, o sol e o vulcão erguem-se como alegorese, deslocados para o topo do crânio, onde, em latência, está o "olho pineal", órgão da consumação. ${ }^{92}$ Essa ideia reforça o ponto de vista do recalcado no mundo heterogêneo enquanto parte maldita. Esta, na alegoria vulcânica, é a soberania da lava tornada excedente pela corrosão das encostas do mundo homogêneo. "Maldita", por exteriorizar, da animalidade, o que é intolerável, e que por isso mesmo se deseja. A homogeneidade é aquilo que não suporta o excedente, sobretudo quando este se faz representar por signos de consumação do corpo. Em $O$ ânus solar, as erupções vulcânicas são descritas como excedente expelido pelos orifícios anais da terra:

O globo terrestre está coberto de vulcões que lhe servem de ânus.

Ainda que este globo não coma nada, ele despreza expelindo, por vezes, o conteúdo de suas entranhas.

Este conteúdo jorra estrondosamente escorrendo nas encostas do Jésuve, espalhando por toda parte o terror e a morte. ${ }^{93}$

\footnotetext{
${ }^{89}$ H.H.Read, Geologia: uma introdução à história da terra. Mira-Sintra: Publicações Europa-América, 1976, p. 86.

90 O.C., II, "Dossier de l'oeil pineal", p. 28.

${ }^{91}$ Id., ibid., p. 14.

92 Id., ibid., p. 25.

${ }^{93}$ O.C., I, L'anus solaire, p. 85.
} 
Este deslocamento, para o baixo-corporal, de topoi considerados grandiosos, como o sol ${ }^{94}$ e o vulcão, evidencia dois movimentos da escrita: o de destruir ou sacrificar o aspecto solene, espiritual, das palavras, e o de potencializá-las in extremis como signos de excesso e de dispêndio. Também, em um relato de $O$ culpado, Bataille relaciona a experiência do dilaceramento dispendioso com a da irrupção vulcânica:

[...] a lembrança do monte em Etna me veio ao espírito e me transtornou:...estávamos esgotados e, de algum modo, exorbitados por uma solidão demasiado estranha, desastrosa: é o momento de dilaceramento em que nos inclinamos sobre a ferida beante... ${ }^{95}$

Deixe-se ecoar, nestas imagens vulcânicas do excesso, outra em mesma chave, desta vez do marquês de Sade, neste ponto de La nouvelle Justine, a maior e mais violenta das três versões desse romance. Quem fala é o monge libertino Jérôme, evocando uma viagem à Sicilia:

Um dia, observando o Etna cujo seio vomitava chamas, desejei ser o célebre vulcão.

- Boca dos infernos, exclamei, admirando-o, se como tu eu pudesse engolir todas as cidades ao meu redor, quantas lágrimas não faria correr? ${ }^{96}$

Aqui, mimetiza-se o excesso da natureza como possibilidade de ação entre os homens visando à efusão lacrimosa. O gozo da operação pode estar tanto no excesso, quanto nos efeitos dissolventes deste como gasto. Em Sade, o fenômeno natural se perverte, ressaltando-se a relação entre a literatura e o mal. ${ }^{97}$ Por mais que os homens procurem se abrigar sob os ideais da virtude, da piedade, do bem comum, etc., as relações de forças sempre descambam para a dominação de uns sobre os outros: é o signo da

\footnotetext{
94 "O sol, humanamente falando (quer dizer, enquanto ele se confunde com a noção de meio-dia), é a mais elevada das concepções. É também a coisa mais abstrata, já que é impossível olhá-lo fixamente neste horário. Descrevendo a noção de sol no espírito daquele que deve desvirilizá-lo, necessariamente, em conseqüência da incapacidade dos olhos, deve-se dizer que este olho tem, poeticamente, o sentido da serenidade matemática e da elevação do espírito". Id., ibid., p. 231.

${ }^{9}$ O.C., V, Le culpable, p. 365.

${ }^{96}$ Sade, La nouvelle Justine. Paris: Union générale d'éditions, 1978, v. II, p. 478.

${ }^{97}$ Bataille afirma que a literatura expressa o mal, ao menos em sua "forma aguda", e que ele tem, para nós, um "valor soberano". Por isso, a literatura não é "inocente", mas "culpada", revelando um impulso infantil de afrontamento da autoridade. Para Bataille, portanto, a verdadeira motivação do texto e de sua leitura está na relação com o mal. Do contrário, a literatura perde o interesse ou se torna insípida. Ver O.C. IX, La littérature et le mal, pp.171-172. Do mesmo modo, Sade defende a tese segundo a qual toda virtude deve ser "atormentada pelo vício" nos romances, como modo de despertar o interesse do leitor. Cf. D.A.F. de Sade, "L'idée sur les romans". In: Les crimes de l'amour. Paris: Jean-Jacques Pauvert, 1961, vol. I, p. 27.
} 
desmedida como fundamento da intensidade da vida e da consumação de si. Os laços entre os poderosos assim se confirmam e se consumam como forma de dominação e afirmação da vida até na morte.

Há em Bataille a afirmação de que o "verdadeiro excedente" é o gerado pela superabundância, portanto, força maior e variada que age sobre o outro sem arruinarse na ação. O excedente, assim, é usado tanto para o bem (gerar o outro, fazer crescer seu alimento), quanto para a ruína, como é mister entre os libertinos de Sade. Em qualquer caso, o excedente é soberano, constituindo-se como a sem razão do excesso. Favorecendo a uns e prejudicando a outros, o excedente dos seres tem, pois, relação direta com os acontecimentos da ruína e da morte.

No paradigma solar está presente essa dinâmica, cuja economia preconiza a despesa no lugar da produção. É o princípio do potlatch: só podem dilapidar-se a si mesmos aqueles que experimentam o poder e o limite da própria exuberância. Como o limite assinala, não apenas impossibilidade de crescer, mas, principalmente, o fato de que a superabundância é um princípio de excesso, que gera o gasto desenfreado, o potlatch é a cultura da heterogeneidade, pois coloca a sociedade sob o signo da exuberância e da dilapidação. Do ponto de vista do mundo homogêneo, a despesa é um mal, sendo esta a razão pela qual essa relação é rompida, só retomada pelas condutas soberanas da heterogeneidade, vale dizer, pela experiência. $O$ mundo homogêneo só reconhece os acontecimentos da heterogeneidade como formas de exceção circunscritas em campo próprio, excluídas da esfera da utilidade. Sendo a experiência exceção, tolerada pelo mundo homogêneo como acontecimento de margem, é a ele exterior. $O$ caráter inoperante da despesa evidencia a relação entre o limite e o excesso, relação análoga àquela que, no plano da moral, do direito e da religião, é caracterizada como interdição e transgressão, termos que assinalam o que é relativo ao limite e ao excesso, respectivamente, na ótica do mundo homogêneo. O ideal, para este, é que os acontecimentos da experiência sejam sempre considerados fenômenos exteriores. O que torna Bataille uma voz isolada nas discussões sobre economia, é que ele faz observar em lei aquilo que nelas em geral representa o que deve ser controlado. 
Nas culturas do potlatch, o sol constitui o paradigma da despesa como entre os astecas, que praticavam despesas suntuárias e tomavam o astro por deus. Diz Bataille que os astecas estavam tão ocupados em sacrificar, como nós em trabalhar. ${ }^{98} \mathrm{~A}$ prática da despesa improdutiva Ihes permitia edificar pirâmides no alto das quais imolavam. ${ }^{99}$ É a lógica do dispêndio, contrária à do desempenho no mundo homogêneo.

Da dilapidação sem reservas dos recursos de energia à prática desmedida das orgias, a história se faz acompanhar pelas experiências de consumação, como o erotismo, o sacrifício, o êxtase, a poesia e por todas as modalidades de ruína que culminam na morte, a qual, como diz Bataille, "de todos os luxos concebíveis" [...] "em sua forma fatal e inexorável, é certamente o mais dispendioso". ${ }^{100}$

A morte é a comprovação categórica da supremacia da despesa sobre a produção. As exigências de gasto e de excesso que as condutas soberanas fazem consumar pela experiência até a morte, constituem a parte maldita, o legado insuportável dos seres degenerados.

\footnotetext{
${ }^{98}$ La part maudite, op., cit., p. 52.

${ }^{99}$ Id., ibid., p. 52.

${ }^{100}$ Id., ibid., p. 40
} 


\section{III.O PRINCÍPIO GERADOR}

\section{Superação e limite: a recorrência do excesso}

A noção de excesso, excessivamente recorrente em Bataille, indicia o que não pode ser determinado. $O$ discurso refere o excesso, mas não exprime a experiência do excesso, a qual se caracteriza justamente por ocorrer à margem do que se constitui como verdade do discurso: o referido não traz, pois, aquilo que em substância acontece e está atrelado ao movimento da superação. A dobra da linguagem encobre o essencial que não se reduz a ela: o movimento do excesso enquanto intensidade e atividade. Tomando o excesso como pura referência, o discurso o neutraliza, imobilizando-o na linguagem, sem que venha à tona, nesta, a atividade e a intensidade que levam à superação na experiência. Em suma: o que se diz do excesso resvala na linguagem, deixando de fora a experiência. Bataille afirma-o alegoricamente: "o que conta não é mais o enunciado do vento, é o vento". ${ }^{101}$ Ora, a diferença entre experiência e filosofia, é que "na experiência, o enunciado não é nada, senão um meio, ou, não apenas isto: é também obstáculo". ${ }^{102}$ Enquanto meio, o discurso apenas se dobra sobre si mesmo, reiterando seu lugar ilhado no mar do excesso, pois se constitui como inter-dito em relação a ele, como pragmática discursiva. Embora esteja na base do pensamento e da linguagem, o excesso é soberano e não pode ser, pois experiência, pensado ou dito. Ou seja: um enunciado pode ser feito numa relação com o excesso, mas a experiência excede o discurso que se empenha em dizê-la. Não poderia ser diferente: o excesso explicita o princípio da despesa, jamais o de desempenho. Ao fazê-lo, a razão perde o leme, o sujeito naufraga no gozo e na consumação de si.

A primazia da experiência sobre o discurso, em Bataille, implica outro efeito: o campo do conhecido é excedido pelo do desconhecido ou não-saber. A noite silenciosa

\footnotetext{
${ }^{101}$ O.C. V, L'expérience intérieure, p. 25.

102 Id., ibid., p. 25.
} 
do último arrebata a trilha iluminada do primeiro. $\mathrm{O}$ agente que representa este movimento na vida é a sorte, chance.

Minhas reflexões sobre a sorte estão à margem do desenvolvimento do pensamento. [...] Descendo no mais profundo, elas tiram a cadeira daquele que espera, do desenvolvimento do pensamento, a possibilidade de se sentar, de descansar. $^{103}$

A sorte remete ao desconhecido, põe tudo em jogo, pois manifesta o não-saber; imprevisível, incalculável, alheia ao logos, força do instante, contrária a todo projeto, ela faz valer a autoridade, subordinando os seres, afirmando-se soberanamente: a sorte é consumação e vontade de excesso.

\begin{abstract}
Dois movimentos de natureza oposta buscam a sorte, um de rapto, de vertigem; o outro de acordo. Um quer a união brutal, erótica; o azar (malchance) se precipita vorazmente sobre a sorte, consumindo-a, ou ao menos a abandona, marcando-a com o signo nefasto: um momento abrasado - o azar segue seu curso ou se acaba na morte. O outro é adivinhação, vontade de ler a sorte, ser dela o reflexo, perder-se em sua luz. [...] A sorte nasce da desordem e não da regra. ${ }^{104}$
\end{abstract}

Assim, no duplo movimento que caracteriza a relação com a sorte, há o reconhecimento de que ela é sempre potência ativa e, enquanto tal, vontade de excesso. O primeiro movimento de busca da sorte implica a experiência propriamente dita, e conseqüentemente a consumação: daí seu sentido de rapto ou vertigem. É esse movimento que mais interessa a Bataille por constituir a sorte como singularização do corpo pela potência do excesso. Do ponto de vista do corpo, não há como se relacionar com a sorte senão no deixar-se subordinar à sua ação soberana, à sua autoridade. $\mathrm{O}$ efeito danoso para o corpo no que diz respeito à homogeneidade é o caráter maligno da sorte modalizada como azar. Por isso, como sempre em Bataille, a sorte implica a angústia para o sujeito, mas esta também representa o que desencadeia a experiência e a consumação de si. Daí a busca de um acordo com a sorte por parte do mundo homogêneo. Não podendo a ciência obtê-lo, por ser a natureza da sorte avessa à lógica, apela-se aos procedimentos esotéricos. Pois, "a sorte nasce da desordem e não

\footnotetext{
103 O.C. V, Le coupable, 312.

104 Id., ibid., p. 314.
} 
da regra". O único modo de enfrentá-la é submeter-se a seu movimento sob o princípio do excesso gerador, consumando-se em pura perda a experiência.

\begin{abstract}
A sorte é o efeito de uma jogada (mise en jeu). Este efeito jamais é um repouso. Incessantemente reposta em jogo, a sorte é o desconhecimento da angústia (na medida em que a angústia é desejo de repouso, de satisfação). Seu movimento leva à única finalidade da angústia: a ausência de resposta; ele não pode sobrepujar a angústia, pois, a fim de ser sorte e não outra coisa, deve desejar que a angústia subsista e que a sorte permaneça em jogo. ${ }^{105}$
\end{abstract}

O movimento da sorte que mantém relação ambígua com a angústia (de superação e permanência) é a afirmação soberana do excesso enquanto potência ativa. Do ponto de vista do sujeito, isso implica o colocar-se imediatamente em jogo e o submeter-se à vontade da sorte. No extremo: "o ser nos é dado numa superação intolerável do ser, não menos intolerável que a morte". 106

A superação, assim, é gerada pelo excesso da sorte, cujo efeito intolerável é a morte como desmedida. Sendo o excesso força, ele também é desmedida, o que está fora de controle. $O$ excesso se identifica com a morte, enquanto esta excede a vida. $A$ morte assinala o limite, já que, superando a vida, exterminadora, nada oferece que seja excedido. Ao mesmo tempo, para Bataille, intensificada pela experiência e favorecida pela sorte, a vida excede a morte, de que são exemplos os vermes proliferando sobre o cadáver. ${ }^{107}$ Vida é pluralidade. $O$ fato de a morte exceder a vida e representar para esta um limite só pode ser considerado, portanto, em relação a cada ser em particular. Apesar de sua descontinuidade, o que liga o indivíduo à vida é "o sentimento de continuidade" ocasionado pela experiência soberana do excesso, no erotismo, no sacrifício, na poesia, no êxtase. Eis porque, para Bataille, "o erotismo é a aprovação da vida até na morte". ${ }^{108}$ Assim, embora, liquide a vida individual e represente o excesso maior, a morte não deixa de estabelecer um limite que pode ser excedido pela própria vida enquanto pluralidade. Isto acontece porque o excesso é princípio gerador, representando a continuidade dos seres.

\footnotetext{
${ }^{105}$ Id., ibid., p. 317.

106 O.C., III, Préface à Madame Edwarda, p. 11.

107 O.C., X, L'érotisme, p 108.

${ }^{108}$ Id., ibid., p. 109.
} 
Assim, uma força viva pode ser superada por outra maior: ocorrem experiências de aceleração e, em geral, de intensificação, nas quais ao mesmo tempo em que um limite é superado, outro imediatamente se estabelece. O excesso tem, portanto, um duplo aspecto: o da superação e o do limite. A superação, vimos, é o movimento do excesso que expõe o ser ao que Ihe é intolerável. Por sua vez, o limite só pode ser entendido a partir de uma relação com este intolerável, tornando-se o ponto em que este cede ao sentido, rendendo-se, pois, na tolerância, ao que os homens estabelecem como lei, discurso. Assim, quando o limite instituído (a interdição) pelo mundo homogêneo é superado, este movimento de superação se explicita como transgressão, manifestando o caráter intolerável do excesso.

Para Bataille, é a interdição que desencadeia a transgressão: o limite fixado pelo mundo homogêneo na forma da interdição é o que confere ao excesso um caráter transgressivo. Por meio dos interditos, o mundo homogêneo busca ocultar o intolerável que desnuda o ser e, na heterogeneidade, o coloca em risco. Recalcado, esse intolerável se ergue como sagrado, que o gesto transgressor quer violar. Deste modo, enquanto o interdito sinaliza como limite, o excesso age como princípio ativo da transgressão, forçando a superação desse limite. Bataille: "a transgressão não é a negação do interdito, mas o ultrapassa e o completa". ${ }^{109} \mathrm{O}$ movimento que entrelaça o interdito e a transgressão reforça não apenas as necessidades da superação e do limite num jogo de contrários que se afirmam sem se anularem na relação recíproca. Nas palavras de Foucault:

\begin{abstract}
A transgressão é um gesto relativo ao limite. [...] $O$ jogo dos limites e da transgressão parece ser regido por uma obstinação simples: a transgressão transpõe e não cessa de recomeçar a transpor uma linha que, atrás dela, imediatamente se fecha de novo em um movimento de tênue memória, recuando então novamente para o horizonte do intransponível. Mas esse jogo vai além de colocar em ação tais elementos: ele os situa em uma incerteza, em certezas logo invertidas nas quais o pensamento rapidamente se embaraça por querer apreendê-las. 110
\end{abstract}

\footnotetext{
${ }^{109}$ Id., ibid., p.109.

${ }^{110}$ M. Foucault. "Prefácio à transgressão". In: Ditos e Escritos, vol. III, Rio de Janeiro: Forense universitária, 2001, p. 32.
} 
Logo, é a transgressão que na superação assinala o caráter intransponível do limite, condição, no entanto, para todo gesto transgressor já que sem a interdição ele não faz sentido. É isso que evidencia a transgressão como uma recorrência do excesso que por meio dela se revela força, arriscando o ser na experiência e expondo-o ao intolerável. Com isso, se restabelece a continuidade num âmbito geral que caracteriza, do ponto de vista do excesso gerador, uma dinâmica que se perpetua no domínio dos seres e da linguagem. Pode-se, então, conceber uma multiplicidade de forças excedendo-se umas às outras em ritmo, duração e sentido variáveis. Tal multiplicidade caracteriza o movimento do excesso no mundo dos seres nas diversas modalidades de atualização da potência.

Os homens são seres descontínuos porque morrem, por isso, buscam a continuidade. ${ }^{111}$ A continuidade (ou seu "sentimento", como diz Bataille), é alcançada nas experiências do excesso como o erotismo, o sacrifício, o êxtase e a linguagem poética. É sempre a mesma dinâmica no âmbito natural e humano, em que a morte é o limite e ao mesmo tempo efeito de superação da vida pela vida, conferindo-lhe um sentido de continuidade: a doença supera a vida arruinando-a até a morte, mas a operação soberana dos vermes, em sua efervescência proliferante, excede a morte com a vida: imagem emblemática de Bataille: não há pacificação possível, pois não há como regular o movimento da sorte enquanto princípio do excesso gerador.

Quanto ao discurso, se ele pacifica referenciando os seres e coisas com o princípio da identidade, do primado do sentido e da razão, o faz num âmbito restrito, pois não sai de si mesmo, deixando de fora, como exterioridade pura, as forças heterogêneas do excesso que estão na base de toda operação soberana. Aquilo que o discurso rejeita como excesso e gasto confere soberania à poesia como atividade improdutiva, a qual, por sua vez, excede os sentidos fixos do discurso homogêneo para afirmar-se na consumação da linguagem e do sujeito. A consumação de si (do sujeito e das palavras) comunica, por meio da poesia, a autoridade e o método da experiência, sendo a poesia o campo simbólico da consumação.

Retome-se a ideia de Bataille segundo a qual o movimento do excesso gera imediatamente uma cadeia de efeitos identificados pelo mundo homogêneo como

${ }^{111}$ O.C., X, L'érotisme, p.108. 
violência e transgressão. As ações que os desencadeiam são descontínuas, por isso mesmo limitadas, mas se efetuam no impulso de uma continuidade entendida como vontade de excesso. Klossowski a respeito de Nietzsche: "se, na origem, ela [a potência] é um excedente que engendra um novo excedente simplesmente para subsistir, torna-se cada vez mais difícil distingui-la dos excessos aos quais leva o esgotamento". ${ }^{112}$ Ativa, a potência se afirma como aquilo que pode sempre mais, e nesse aspecto se confunde com o excesso que a atualiza no domínio dos seres e da linguagem, exigindo a consumação. Assim, no domínio dos seres e da linguagem, toda atualização da potência condiciona o mais ao limite da consumação: os seres se arruínam no excesso, a linguagem se desgasta na poesia. Vemo-nos, portanto, entre a superação e o limite.

Mas por que a superação é intolerável para Bataille? A pergunta remete aos efeitos do excesso no corpo: para este afirmar-se, na experiência, tem de negar a consciência (o sujeito) no movimento arrebatador da superação. A experiência do excesso implica deste modo uma súplica sem resposta e sem sentido porque excede todo saber, provocando o efeito que Bataille denomina de "mancha cega", tache aveugle, na estrutura do sujeito. Deste modo, a experiência (do sacrifício, do erotismo, da poesia, do êxtase) é o acontecimento no qual o sujeito, desvinculado de toda relação de saber, se consuma diante do intolerável, na ignorância do não-saber. Como se viu, a sorte é a determinação que coloca o sujeito na perspectiva do excesso gerador. Ela, assim, é análoga àquela que, em Nietzsche, se denomina vontade de potência, ou seja, o princípio ativo da força. ${ }^{113}$ A sorte é sempre ativa, explicitando, no excesso, a vontade. Por isso mesmo, a sorte é a condição para a superação, constituindo-se como vontade de excesso. Dotado de vontade e por meio da sorte, o excesso se comunica com os seres, agindo sobre eles. Deste modo, na perspectiva do sujeito, a sorte é almejada como possibilidade de superação, já que ela é vontade de excesso, sem a qual nada pode ser superado.

Finalmente, há na superação um ponto de saturação do excesso que se confunde com o extremo do possível, ou seja, com o limiar mesmo do impossível, para

\footnotetext{
${ }^{112}$ P. Klossowski, Nietzsche e o círculo vicioso, op. cit., p. 109.

${ }^{113}$ Ver L.Kossovitch, Signos e poderes em Nietzsche. Rio de Janeiro: Azougue editorial, 2004 , p. 38.
} 
falar nos termos de Bataille. O paradoxo do impossível é que ele contém em si a possibilidade de um excesso sem limites, o qual, sendo potência ativa, gasta seu excedente com os seres, sem deixar de ser o que é. Mas o mundo homogêneo condiciona os seres apenas no horizonte da possibilidade. Por isso, para Bataille, este é "o mundo dos possíveis", concebido de espaços demarcados e de ações controladas pelos dispositivos institucionais. A razão homogênea estabelece os interditos e constitui as transgressões, mas não pode evitar as condutas soberanas do gasto que vêm à tona na experiência. Esta, por sua vez, responde pelo corpo colocando-o na via da sorte e da consumação de si. Por meio da experiência, o corpo excede; como potência ativa, atinge a continuidade. Como isso ocorre no plano dos seres em que o ato é limitado pela própria consumação e, no extremo, pela morte, ao corpo só resta colocar-se em jogo, expor-se nuamente à sorte, enquanto vontade de excesso.

Em Bataille, expressões como "vontade de ápice" e "princípio de insuficiência" exprimem a vontade de excesso e as exigências de gasto na cultura, trazendo à tona a parte maldita. Por mais que aquela assimile os movimentos do excesso e novos limites sejam estabelecidos como interditos, esta dinâmica se mantém, pois, o princípio ativo da transgressão é sempre a vontade de excesso, mas no ponto em que esta se vincula ao interdito como possibilidade de superação. Assim, o intolerável sempre ressurge por meio de um excesso maior, abrindo no sujeito a ferida da angústia, expondo o corpo à sorte, no limiar do impossível. Como o que caracteriza o excesso é sempre a possibilidade de superação do limite (pois de outro modo não haveria percepção do excesso), o mundo homogêneo, além de não se livrar da transgressão, ainda colabora para que ela aconteça, demarcando seu domínio com interditos.

Quando os efeitos desencadeados pelo excesso chegam a um ponto intolerável, é porque o limite já não serve de medida e o movimento excessivo se cumpre no extremo do possível, vale dizer, no limiar mesmo do impossível.

Por definição, o extremo do possível é este ponto onde, apesar da posição ininteligível que ele tem no ser, um homem, tendo-se despojado de logro e de temor, avança tão longe que não possamos conceber uma possibilidade de ir mais adiante. ${ }^{114}$

\footnotetext{
${ }^{114}$ O.C., V, L’expérience intérieure, p. 52 [ed. bras. A experiência interior. São Paulo: Ática, 1992].
} 
O extremo do possível é, assim, o ponto em que o movimento do excesso, favorecido pela sorte, atinge a superação, instante em que não se concebe a possibilidade de ir mais além, porque o movimento da superação se identifica com todo além possível. Para Bataille, é somente nesse instante que o ser se mostra: quando o movimento da superação que o leva a exceder-se a si mesmo se torna intolerável. É o momento dilacerante da angústia e vertiginoso de subordinação à sorte. Mais não é possível, pois o impossível é sempre mais do que isto.

O intolerável, assim, é um sintoma. Dispondo os seres na perspectiva do excesso gerador, o intolerável anuncia, por meio da angústia e do movimento da sorte, que não há saída para o homem a não ser a experiência e a consumação.

Assim, o intolerável que explicita a superação abre para todas as possibilidades do excesso até o limiar a partir do qual o impossível se insinua. Não "conceber uma possibilidade de ir mais adiante" significa atingir a linha divisória entre o limite e o impossível: se um determinado ponto é atingido, no extremo do possível, é porque ele coincide com o limite e esta operação é a última que a razão pode realizar antes da consumação de si na experiência. Por isso, para Bataille, a experiência comunica o não-saber do impossível. O "sentimento de continuidade", aliás, é seu efeito imediato: continuidade em relação à potência do excesso, mas descontinuidade na perspectiva da razão homogênea, na qual o limite implica a consciência e o entendimento. Nesta perspectiva, gerada pelo excesso, a heterogeneidade corresponde ao que é tido por degenerado no mundo homogêneo.

Com efeito, o que confere sentido à superação é precisamente o limite; o limite em si mesmo é um sentido, um arbítrio, a determinação de algo no tempo e no espaço do pensamento e do discurso. É assim que o limite se prescreve como interdito no mundo homogêneo. O limite é a fronteira que divide os campos do conhecimento e do não-saber, do discurso e da poesia, da razão e da loucura, enfim, o que em última instância distingue o possível, pensável e imaginável, do impossível, que se atém exclusivamente à potência plena do excesso em seu temerário silêncio. 


\title{
O Uno como potência do Bem e o ser gerado como "vida manca"
}

Encontra-se em Plotino a ideia do Uno como princípio gerador. Sua característica principal é gerar a si mesmo e, de sua exuberância, tudo o que vem depois. Portanto, ele gera excedendo o limite em geral. A definição plotiniana do Uno:

\begin{abstract}
Que é propriamente? Potência de todos os seres a qual, se não existisse, não existiriam nem a totalidade dos seres e nem mesmo o Espírito - vida primeira e total. Mas, o que está acima da vida é causa da vida: já que não é a atividade da vida - isto é, a totalidade dos seres - que é em primeiro lugar, mas ela é exatamente como se brotasse de uma fonte. Pensa, com efeito, em uma fonte que não tenha outro princípio senão a si mesma e que, no entanto, de si mesma dê a todos os rios sem nunca deixar-se esgotar, mas em si permaneça tranquilamente; pensa ainda nos rios que dela nascem, os quais, antes de correr separados daqui e dali, por um trecho ainda estão juntos; mas cada um sabe, por assim dizer, por onde se derramarão as suas correntes. ${ }^{115}$
\end{abstract}

Na figura plotiniana, os rios são formados pela fonte, mas, aos poucos, se afastam dela guardando, no entanto, o vínculo principal, o sentido de continuidade. O Uno, deste modo, mantém, numa relação de continuidade as coisas que gera, as quais são, propriamente, efeito de sua potência no plano dos seres. É nesse sentido que ele é potência ativa.

O Uno se identifica ao primeiro e supremo Bem. "Permanecendo imóvel, ele é o princípio e a fonte de todos os atos naturais". Assim, "para cada ser, o bem é uma vida que está em conformidade com seu ato natural". ${ }^{116} \mathrm{Em}$ sendo o Bem o perfeito Uno, por que também não seria, pergunta Plotino, o princípio de tudo? Ora, "se devem existir coisas diversas dele, então elas dependem dele para seu ser, pois não há outro princípio que as possa gerar. ${ }^{117}$ No entanto, nem todo ser gerado é bom. Por vezes, ele se desvirtua, pois, explica Plotino, "não cumpre direito aquilo que lhe é próprio fazer". O desvio é figurado pelo filósofo no exemplo seguinte: "no malévolo, a vida é manca - ela é como o olho que tem a vista turva". 118

A propósito, o olho "malévolo", de "vista turva", é imagem recorrente na obra de Bataille desde seu romance de estréia, $A$ história do olho, assinado por um

\footnotetext{
${ }^{115}$ Plotin, Ennéades, V. Paris: Société d'édition, “Les belles lettres”, trad. Émile Bréhier, 1960, p. 109.

${ }^{116}$ Plotin, id., ibid.

117 Plotin, id., ibid.

118 Plotin, Ennéades, I. Op., cit., p. 109.
} 
pseudônimo. ${ }^{119}$ Bataille fala de um olhar enraizado no mal, que só pode reproduzir o que há de mais terrível na vida: não há salvação para o homem: o "primeiro Bem gerador" de que fala Plotino não existe e em seu lugar não há senão súplica no vazio, noite escura, subordinação à ignorância da sorte de uma existência sem sentido. Daí a vontade de excesso e a exigência de gasto como respostas soberanas do corpo, o qual, sem finalidade e sem salvação, excede limites e, na experiência, se consuma. Por isso, há em Bataille "um desejo tenaz de ver com olhos revirados, como os cegos". ${ }^{120}$ Quem olha deste modo não vê. É um olhar espanado, voltado para dentro, perdido na própria consumação. Para o mundo homogêneo, trata-se do olhar que caracteriza o malévolo e predispõe ao mal. Há nisso o reconhecimento de que o ser gerado traz em si mesmo a marca de um desvio com relação ao Bem. O olhar turvo perde o Um, tornando-se um atributo do ser gerado que se repete indefinidamente. Assim, por efeito de derivação hipostática, o ser gerado de Plotino não implica aqui a perfeição do Bem original. A vida que o anima é manca. É esse caráter irreversível que ela lega enquanto simulacro às futuras gerações: a repetição é a marca dessa vida manca e seu defeito congênito, a essência do ser degenerado. Potência ativa no mundo dos seres e na linguagem, essa vida faz proliferar os efeitos danosos do mal em todas as relações que estabelece. Sua sorte não pode ser outra, e afirma, enquanto potência ativa, tudo aquilo que o mundo da razão e do trabalho renega: a desmedida, a transgressão, a gastança, a consumação cega, o azar, a ruína, a morte, enfim, os efeitos que a atualização da potência do excesso desencadeia no domínio do degenerado.

Para Bataille, o mal designa aquilo que o mundo homogêneo entende como excesso, condenando a inoperância por levar à despesa desenfreada e à ruína da consumação de si. Deste modo, o ato desviante fatalmente transgride e torna culpado o sujeito da transgressão. Esta, não por acaso, é a tônica do cristianismo: afirmar o interdito e condenar a transgressão: Felix culpa! Nesta perspectiva, toda conduta desviante das prerrogativas do mundo homogêneo assentado sobre o fundamento do

\footnotetext{
${ }^{119} \mathrm{O}$ dado é significativo levando-se em conta a explicação do próprio Bataille a respeito deste pseudônimo, "Lord Auch", expressão combinatória da corruptela "Auch", de chier (cagar), aludindo ao modo como um amigo se exprimia: "aux chiottes", e da palavra "Lord" (Deus),que Bataille recontextualiza como "Deus se aliviando". V. Bataille. O.C., I, L'histoire de l'oeil, p. A imagem também recorre à figura paterna, cega e sifilítica, conotando, para todo efeito, o sentido de um princípio criador (o pai ou deus) defeituoso.

${ }^{120}$ R. Sasso, op. cit., p. 63
} 
Bem gerador (o trabalho, a produção, os discursos, os saberes), persevera no mal. Talvez se possa, como os geólogos, denominar extremófilo ao indivíduo que vive no excesso, enfatizando a philia no sentido da intimidade. A extremofilia é a condição dos que vivem nos extremos, portanto, fora do mundo homogêneo, propensos a uma vida manca: o extremófilo age qualificando a vontade de excesso como um mal que ameaça a razão homogênea. No universo de Bataille, personagens como Simone, Dirty, Madame Edwarda, são extremófilos, bem como todos os grandes libertinos de Sade. Por essa razão, segundo Bataille, a literatura está definitivamente ligada ao mal e por isso mesmo é culpada na perspectiva do mundo homogêneo, levando o sujeito à má sorte e à ruína. O emblema do sujeito fendido é, como se viu, a ferida ou a fenda, fêlure, caracterizada na cultura como angústia, e sua reação desesperada é o riso. A angústia é um sentimento de perda na homogeneidade, implicando a do sujeito, ao mesmo tempo que desencadeia a experiência na qual o corpo se afirma, pelo excesso, como consumação de si: é o que Bataille denomina "experiência interior" ou "experiência extática". O signo que melhor a exprime é o olhar revirado do sujeito em êxtase, emblema de morte da consciência e de afirmação do corpo em excesso.

Deste modo, as condutas heterogêneas representadas pela vida manca reiteram a soberania do degenerado, contrariando a ideia do Bem como princípio gerador. Vinculado à potência do excesso, o extremófilo se arruína, consumando-se em pura perda: a extremofilia é a condição daquilo que persevera pela vontade de excesso e pela afirmação da sorte, visante à consumação.

Ao ressaltar o que há de menos na existência e o que há de falta no ser, a angústia, ferida exposta na flutuação do sujeito, força os limites da vida em direção ao mais, ao impossível. No entanto, em se tratando do impossível, os termos "direção" e "mais", denotando sentido e quantificação só referem o impossível na dobra do discurso, portanto, no campo da possibilidade, onde ele não se encontra. Pura exterioridade, excesso de sentido e não quantificável, seu movimento, certamente, não se apreende. O impossível é, em Bataille, domínio sem dono, sem configuração nem gênero: questão inabordável, mas também incontornável. 


\section{Exuberância e ruína}

Em Bataille, como se viu, a sorte é vontade de excesso dispondo os corpos na experiência, levando-os à consumação de si. Vontade de excesso não é um querer constituído como força ativa, é, antes, manifestação do princípio gerador como força transcendente.

Como se dá a relação entre os seres gerados e o excesso gerador? Recorde-se a afirmação de Bataille, segundo a qual "a história da vida sobre a terra é principalmente ${ }^{121}$ o efeito de uma louca exuberância". ${ }^{122}$ É a natureza do excesso. Daí o efeito de "louca exuberância" daquilo que, em relação à potência do excesso, exubera, ou seja, é gerado como ex-uber, portanto, que sai de dentro da terra, o fecundo, superabundante. No excesso, a força supera um limite, condição de toda superabundância. A conseqüência econômica, mas também ontológica do movimento excessivo da potência geradora é o gasto, a perda, a morte. Em Bataille, o que é gerado no excesso desencadeia as operações do gasto no mundo dos seres e da linguagem.

Nos seres descontínuos, como o homem, a morte limita a vida, mas também representa superação para aquele que está diante do intolerável trazido à tona pela experiência. A morte não deixa de ser, individualmente, afirmação do princípio gerador na descontinuidade, a qual se evidencia como condição do que é gerado. $\mathrm{Na}$ perspectiva do gasto é o que caracteriza o ato e manifesta a vontade de excesso nos seres. $O$ ser gerado não possui as qualidades da auto-suficiência e da superabundância, características do princípio gerador. Por isso, no homem, a exigência de excesso e a vontade de sorte estão ligadas ao princípio da perda e da consumação de si. Sujeito à degenerescência, à ruína e à morte, condição de tudo o que existe, o ser descontínuo só pode participar da continuidade nas experiências heterogêneas do excesso É por essa sem razão que, para Bataille, a experiência é sensibilia, e não sapientia; em suma, são os sentidos que contam, exigindo do corpo sempre mais. Excesso é vontade de potência e esta, como diz Klossowski, "não poderia deixar de

\footnotetext{
${ }^{121} \mathrm{O}$ grifo é meu.

122 O.C.,VII, La part maudite, pp. 39-40.
} 
querer sempre mais potência". ${ }^{123}$ E ela o faz sempre prescrevendo um objetivo, como ocorre no mundo homogêneo: "quando ela transgride um, precisa de outro, até que todos os objetivos imagináveis tenham sido atingidos". ${ }^{124}$ Ora, o objetivo diz respeito à própria exigência de atualização da potência no mundo dos seres e da linguagem, dando aos seres a ocasião do arrebatamento da sorte. Não é outro o caráter daquilo que a potência dispõe na relação com o ato. No entanto, assevera Klossowski:

\begin{abstract}
o fato de que nenhum equilíbrio possa se manter para sempre prova que nenhum objetivo alcançado poderia representar a absorção da massa total da energia: uma desproporção entre objetivo e o meio para atingi-lo exige que haja, desta forma, uma ruptura constante de equilíbrio. A energia ultrapassa sempre o objetivo. ${ }^{125}$
\end{abstract}

É essa ultrapassagem que, rompendo o equilíbrio, representa para Bataille o movimento da transgressão. Se a energia ultrapassa o objetivo deste modo é porque ela gera um excedente que não corresponde ao objetivo, desequilibrando a estrutura do mundo homogêneo. Eis porque o interdito é uma medida de controle, não propriamente do acontecimento que a transgressão assinala, mas do quanta de energia que ela libera. Neste aspecto, a transgressão é um movimento fora de controle. "Se a energia ultrapassa sempre o objetivo, é porque este nunca é a própria energia". ${ }^{126}$ Nos termos de Bataille: a transgressão, animada pela vontade de potência, excede por isso mesmo todo objetivo. Excede porque transgressão (gesto) e interdição (norma) são de natureza distinta, sendo este o motivo pelo qual jamais se encontram. "A transgressão não é negação do interdito, mas aquilo que o ultrapassa e o completa". ${ }^{127}$

No mundo homogêneo, o limite se inscreve como signo de interdição e é este signo que está na base da transgressão. O que está em jogo nessas operações são a vontade de excesso e o desejo de continuidade. Levados pelo princípio que se encontra na base de ambos, os corpos que se relacionam no erotismo, no sacrifício, no estupro, no assassinato, no linchamento e em outras formas de violência, se colocam na via da

\footnotetext{
${ }^{123}$ P. Klossowski, Nietzsche e o círculo vicioso, op. cit., p. 138.

124 Id., ibid.

125 ld., ibid.

126 Id., ibid.

${ }^{127}$ Bataille, O.C., X, l'érotisme, p. 66.
} 
transgressão: "o coito é a paródia do crime". ${ }^{28}$ Isso porque, no excesso, as condutas heterogêneas da experiência se comunicam entre si e se equivalem, seja na relação entre os corpos, seja na relação com os signos.

Por outro lado, como se viu, o ser vive sob o princípio de insuficiência, ${ }^{129}$ e, inoperante, se consuma na experiência pela vontade de excesso. A correlação reforça o caráter heterogêneo do degenerado, o qual, pela vontade de excesso, se expõe ao movimento da sorte, podendo ser excedido por ela, e arruinar-se. É a condição do degenerado no mundo homogêneo.

Ora, só o que é superabundante e auto-suficiente pode gastar sem perdas, tal o princípio gerador. Este gera, além de si mesmo, indefinidamente, para além do limite de seu próprio crescimento; sem os mesmos atributos, o ser gerado se consuma em pura perda. Quanto mais esta operação se desvincula do sistema produtivo do mundo homogêneo, mais ela se torna soberana do ponto de vista do gasto e da consumação de si. O soberano é o improdutivo cujo corpo vive em excesso. Recorde-se, aqui, a frase do marquês de Sade, a qual Bataille toma por divisa e que soa como uma máxima: "Não existe melhor meio de se familiarizar com a morte que o de ligá-la a uma ideia libertina". ${ }^{130}$ Aprovar a vida, na experiência erótica, implica acolher a vontade de excesso e satisfazer as exigências de gasto até na morte. É o ponto em que o excesso encontra o limite, pois aquele que sinaliza sua intensidade máxima, donde o sentimento de continuidade; esta se reitera em experiências análogas, se multiplica e se mantém por mais tempo numa cadeia de excessos. No enunciado de Bataille: "O erotismo é a aprovação da vida até na morte", o termo inclusivo complementa o sentido do excesso, ligando-o ao intolerável da superação. O impossível é o passo além, mas então já não haverá volta, nenhuma possibilidade de entendimento: a experiência nos terá consumado.

Retome-se mais uma vez o romance de Sade, no qual se encontra uma descrição do excesso enquanto princípio gerador. Agora, o naturalista Almani explica ao monge libertino Jerôme as razões que o levam a praticar o mal:

\footnotetext{
${ }^{128}$ Bataille, O.C., I, L'anus solaire, p. 81.

${ }^{129}$ O.C., X, l'érotisme, p. 28.

${ }^{130}$ Id., ibid., p. 29.
} 
... O motivo por que me entrego ao mal nasceu do profundo estudo que fiz da natureza. Quanto mais procurei surpreender os segredos dela, mais pude vê-la unicamente ocupada em prejudicar os homens. Segui-a em todas as suas operações: só a encontrareis voraz, destruidora e má; jamais outra coisa senão inconseqüente, contrariante e devastadora. Lançai os olhos, por um momento, sobre a imensidão dos males que sua mão infernal espalha sobre nós. De que serviu nos ter criado para nos tornar tão infelizes? Por que nosso triste indivíduo, como todos aqueles que ela gera, sai de seu laboratório tão repleto de imperfeições? Não vos parece que sua arte assassina só quis formar vítimas... Que o mal seja seu único elemento e que ela é unicamente dotada da faculdade criadora para cobrir a terra de sangue, de lágrimas e de luto? Que só gasta sua energia para estender suas calamidades? ${ }^{131}$

Aqui, o princípio gerador é representado pela natureza que explicita o excesso como força devastadora. O excesso gerador adquire, assim, num sentido oposto ao de Plotino, um caráter maligno. O mal deixa de ser um efeito exclusivo das criaturas que se desviam do bem no mundo, para ser assumido universalmente como vontade incontrolável de excesso. Ademais, a finalidade da natureza é "unicamente prejudicar os homens", porque o mal é "seu único elemento". Entendido na perspectiva de seus efeitos, o mal é atualização plena da potência do excesso, qualificando a sorte de azar, malchance, para aqueles que servem de vítimas. Como a prática do mal implica a transgressão de limites, o movimento que o desencadeia corresponde à vontade de excesso, concebida em toda a sua extensão e intensidade.

É certo que em Sade a natureza ocupa o lugar de Deus, tanto para comprovar a impotência d'Este diante dos flagelos humanos, quanto para enfatizar sua inferioridade, o que pode ser traduzido em termos de uma sem razão superabundante do excesso que só gera para destruir e "só gasta sua energia para estender suas calamidades". Ou, como diz Bataille: "o sistema de Sade é a forma ruinosa do erotismo". ${ }^{132}$ O sentido do mal, assim, corresponde a seu efeito de destruição nos seres, quando a sorte, pela vontade de excesso, é sobrepujada pela má sorte, dando ocasião aos "infortúnios da virtude", que Sade introduz com seu habitual toque de ironia, tão corrosivo quanto eficaz em sua demonstração sistemática.

Mas a superabundância em si mesma não introduz qualquer moral. Ela é simplesmente efeito da vontade de potência nos seres, levando-os à plenitude, isto é, a

\footnotetext{
${ }^{131}$ Sade, La nouvelle Justine, op., cit., pp. 479-480.

${ }^{132}$ L'érotisme, op., cit., p. 170.
} 
um sentido de intensidade máxima e de afirmação da vida até na morte. Por força do excesso, no entanto, o que é pleno e desmedido em intensidade no mundo dos seres invariavelmente se deteriora, se consome, sendo destruído. A superabundância é a condição primeira da potência, o que faz dela o que é. Seria inconcebível, pois, que a potência faltasse a si mesma: a potência é potência até para não gerar, permanecendo em si mesma como impotência, adynamía. É o que afirma Agamben, interpretando esta frase de Aristóteles: "O que é potente pode tanto ser como não ser. Posto que o mesmo é potente tanto de ser quanto de não ser". ${ }^{133}$

O primado do gasto ou da perda, assim, não é mais senão o movimento do excesso gerador no plano material dos seres, seu efeito imediato e limitante. $\mathrm{Na}$ estrutura dos seres, o que gera se desgasta, a superabundância degenera em falta, a vida exuberante definha.

Dois provérbios de William Blake: "Exuberance is Beauty"; "Enough! or Too much". 134

No primeiro, a beleza se identifica com a exuberância; no segundo, o que é "suficiente" se distingue do que é "demasiado". É na exuberância que a beleza revela sua vontade de excesso. Nesse aspecto, a beleza confere a este a poderosa imagem de algo que não se pode apanhar como um objeto. Mas ela é também o signo irradiante do que degenera, se corrompe, como efeito imediato da consumação. A beleza é o começo do que se conhecerá depois como horror, mas ela oculta este efeito enquanto permanece beleza, isto é, enquanto não é consumada inteiramente pelo excesso: os poderes da ruína desintegram seu ideal homogêneo.

Os provérbios de Blake têm relação com o mal e podem ser lidos na mesma chave de seu contemporâneo, o marquês de Sade: gerar é o mesmo que destruir, pois do ponto de vista da vontade de excesso não há diferença entre o bem e o mal. Não é à toa que Blake denomina estes textos de "Proverbs of Hell". O problema para o mundo da razão homogênea é que, sendo auto-suficiente, o princípio gerador coloca o homem na perspectiva da vontade de excesso, dando ocasião para toda sorte de catástrofe. Assim, o mal absoluto só pode ser visto como a mancha em torno da qual toda moral se

\footnotetext{
${ }^{133}$ Ver G. Agamben, Homo sacer - O poder soberano e a vida nua I. Belo Horizonte: Ufmg, 2010, p. 51.

${ }^{134}$ W. Blake, "The marriage of heaven and hell", in The complete poems. New York: Penguin Books, 1977, p.185.
} 
constrói; se ele representa a potência do excesso, só faz sentido como algo exterior às instituições, mas que projeta sua sombra no jogo do interdito e da transgressão. É por isso que, para Bataille, a literatura é "culpada" ${ }^{135}$, tomando parte nesse jogo e animando seu movimento, já que o universo da linguagem consiste no espaço de toda representação possível daquilo que a razão homogênea qualifica de maligno. Em sua operação soberana, a literatura vai ao extremo do possível, colocando-se contra a razão homogênea, isto é, implicando o mal como sua verdade intrínseca e se apresentando como não-saber e violência. Não há como em todas as circunstâncias da vida evitar a exigência deste duplo-movimento. Daí a dificuldade de o indivíduo se colocar o tempo todo dentro dos limites fixados pelo mundo homogêneo. Ao se colocar na via soberana da experiência, deixando-se levar pelas exigências de excesso e pelas demandas de gasto, o homem é deslocado imediatamente para fora da esfera da razão. No extremo dessa operação, ele é inteiramente absorvido pelas forças heterogêneas e se perde na experiência da consumação, vivenciando o que Bataille denomina de "moral do cume"; esta se constitui como recusa dos valores do mundo homogêneo, e, no limite, se expressa no movimento do corpo soberano que suspende todos os valores, para afirmar-se em pura perda:

O cume responde ao excesso, à exuberância das forças. Ele leva ao máximo a intensidade trágica. Ele se liga aos gastos desmedidos de energia, à violação da integridade dos seres. Ele é, portanto, mais vizinho do mal que do bem. ${ }^{13 \hat{6}}$

A moral do cume exprime o sentido de intensidade trágica do corpo soberano. Como nesse movimento o corpo vai ao extremo do possível, ele excede e é excedido, defrontando-se com a própria ruína. Assim, nos termos da economia geral de Bataille, a negatividade sem emprego precipita as condutas que perseveram na inoperância e representam o mal. No mundo dos seres, o ato dispendioso é repetição e, com ela, vem o desgaste: efeito que acomete os seres e a própria linguagem: falta, degenerescência, aniquilamento. Por isso, o mundo homogêneo quer banir as atividades improdutivas que se colocam na via de excesso sob o princípio da perda, confinando-as em espaços

\footnotetext{
${ }^{135}$ O.C., IX, La littérature et le mal, p. 172.
}

${ }^{136}$ Sur Nietzsche, op., cit., p. 42. 
de exceção, como a igreja, a prisão, o hospício, já que não há modo de erradicá-las. O mundo homogêneo quer controlar o gasto desenfreado, tornando o erotismo (excesso de corpo), a loucura (excesso de razão), a poesia (excesso de sentido) e seus efeitos, a violência, a morte, eventos anódinos. Como à razão homogênea interessa mais o trabalho e menos o jogo, menos a poesia e mais o discurso, mais a lógica e menos a paixão, o tempo organizado torna-se tempo ganho; o tempo inoperante, tempo perdido; o futuro, garantia no presente. Em compensação, o tempo futuro se descola do presente, perdendo a relação imediata com a vida, mostrando-se dimensão gregária, voltada para projetos de conquistas em longo prazo e prêmios distantes, em troca da aposta num controle do dia a dia, o mais planejado possível, isto é, evitando a imprevisibilidade do instante, que pode surpreender sempre. Em Bataille, o instante implica o poder de arrebatamento da sorte, instalando a brecha, fêlure, através da qual as forças da violência e da ignorância se expressam em nome da vontade de excesso. Por isso, a razão homogênea quer se apropriar ao máximo da sorte, este acontecimento incalculável e desconhecido para fins lucrativos dentro de uma lógica de desempenho e de utopia em uma felicidade planejada. Nesse ponto, o sentido da homogeneidade está suspenso, as forças heterogêneas se impõem. "Neste instante e até aqui”, como diz Bataille, é o que caracteriza a transgressão ${ }^{137}$, implicando a sorte como agente do excesso no mundo dos seres e da linguagem.

A descontinuidade é a marca dos seres; ferida aberta, no sujeito, representa uma dupla ruptura: a primeira refere-se ao nascimento e está ligada à sexualidade, a segunda relaciona-se com a morte. Perseverando no excesso, os seres se consumam na perspectiva da continuidade, tal o sentido do erotismo, em Bataille, sempre pensado na relação com a morte: a fusão erótica dos corpos, visando à continuidade, também implica àquela, explicitando o gozo e a perda como efeitos da experiência erótica. Do ponto de vista da economia geral, como se viu, isto se descreve pela supremacia do dispêndio sobre a produção. A suficiência da produção leva à superabundância, e superabundância é excesso, movimento de forças heterogêneas o qual, desviando-se do trabalho, desemboca na experiência da consumação de si. Em Bataille, só a soberania da experiência expõe o corpo na continuidade.

\footnotetext{
${ }^{137}$ O.C., X, l'érotisme, p.172.
} 
A consumação é a via da experiência (do erotismo, do sacrifício, da festa, da poesia, do êxtase), portanto, das operações soberanas do gasto. Por isso, segundo Blake, "a Prudência é uma rica, feia e velha donzela cortejada pela Impotência". ${ }^{138} \mathrm{O}$ mundo homogêneo pode assim ser caracterizado; nele, a prudência corrobora a força que coíbe a violência da transgressão, potência do excesso. Mas o princípio do excesso gerador age justamente a partir de um limite, não suporta a contenção: "a cisterna contém: a fonte transborda", ${ }^{139}$ diz este outro aforismo de Blake. Por esta razão, o mundo do trabalho produtivo se opõe a toda superabundância: "portanto, o que significa a reflexão do homem sobre si e sobre o ser em geral, se ela é estranha aos estados de emoção mais intensos?" 140 A experiência é um acontecimento que não se pode calcular "na soma dos possíveis" da filosofia: a experiência abre para o não-saber e se comunica com o impossível. A filosofia, ao se debruçar sobre a experiência, separa-se dela (como acontece em Hegel), porque invariavelmente a toma como um objeto. Com isso a filosofia "não sai de si mesma". A experiência, por sua autoridade e método, excede a relação sujeito-objeto que está na base do conhecimento. Vontade de excesso, a experiência se faz na imediaticidade. Seu tempo é o do instante, próprio da consumação, ao contrário da perspectiva do futuro e da ideia de projeto exigidos no conhecimento. Por isso, "no espírito de Hegel, o que é imediato é mal e Hegel certamente teria ligado o que chamo de experiência ao imediato". ${ }^{141}$

Blake comenta a relação entre o excesso e o conhecimento: "os tigres da ira são mais sábios que os cavalos da instrução": ${ }^{142}$ a ignorância como forma de saber, relacionando a ideia de limite, do que é suficiente, ao sentido de superação: "jamais saberás o que é suficiente, se não souberes o que é mais que suficiente". ${ }^{143} \mathrm{O}$ par violência e ignorância se reflete na reação irada contra os dispositivos da "instrução", sua ânsia de esclarecimento, afirmando a superabundância como condição da potência do excesso. O suficiente é a medida da razão homogênea, implicando a produção e o

\footnotetext{
${ }^{138}$ W. Blake, op., cit., p. 244.

139 Id., lbid., p. 18.

140 L'érotisme, op., cit., 248.

${ }^{141}$ Id., ibid., p. 249.

142 W. Blake, O matrimônio do céu e do inferno, op. cit., p. 18.

143 Id., ibid., p. 18.
} 
controle da despesa. O medo do excesso e do gasto desenfreado, no entanto, se resolve na cultura pelo jogo da interdição e da transgressão.

\section{A transgressão como jogo}

O mundo homogêneo produz e tenta conter as forças do corpo no âmbito do trabalho, excluindo o excesso e as operações soberanas que implicam o gasto do corpo improdutivo. Como este sistema não está livre das forças que representam a heterogeneidade e se explicitam na transgressão, ele tenta se proteger por meio das interdições. A transgressão representa as forças heterogêneas do excesso e se constitui como seu devir. Norma, a interdição existe em função do movimento transgressor, mantendo em si mesma a transgressão como possibilidade e adquirindo com isso sentido e complementação. Como ambivalente, a interdição designa ao mesmo tempo o gesto transgressivo e sua proibição. $O$ mundo homogêneo, idealizado como uno, afasta toda interferência heterogênea, livrando-se da exposição à multiplicidade e à diferença, modos operadores do excesso. Não havendo transgressão sem interdição, ambas só se definem por relações mútuas, explicitadas em pares de opostos: mundo homogêneo / mundo heterogêneo; mundo do trabalho / mundo do gasto; mundo sagrado / mundo profano, o que serve para a cultura se moldar a si mesma. Sem poder erradicar a violência do excesso, a cultura é obrigada a assimilá-la, ainda que dentro de certos limites, fazendo das relações entre interdição e transgressão um jogo. Um mundo sem o jogo de ambas seria impensável para Bataille. É no âmbito dessas relações que Bataille entende a filosofia como saber produtivo oposto às forças improdutivas da experiência, as quais vêm à tona no gesto transgressor. Filosofia e jogo, portanto, são inconciliáveis.

O momento da filosofia prolonga o do trabalho e da interdição. Sobre este ponto, nem quero me estender. Mas ao se desenvolver, a filosofia (sem interromper seu movimento), se opõe à transgressão. Se a filosofia passasse da base do trabalho e da interdição (que se combinam e se completam) para a transgressão, a filosofia não seria mais o que ela é, mas sua irrisão.

A transgressão em relação ao trabalho é um jogo.

A filosofia, no mundo do jogo, se dissolve. 
Dar à filosofia a transgressão por fundamento (é o esforço de meu pensamento) é substituir a linguagem por uma contemplação silenciosa. É a contemplação do ser no ápice do ser.

Assim, o propósito de Bataille é substituir o saber homogêneo da filosofia pela atividade do jogo, explicitando a heterogeneidade da experiência ("ápice do ser"), que deste modo se volta para si mesma em "contemplação silenciosa", portanto, para fora da linguagem. Ora, o que significa dar à filosofia a transgressão por base senão fazer dela um jogo em que os procedimentos do filósofo (crítica, análise, produção do saber) deixam de vigorar em nome da contemplação. Esta, a rigor, não produz. Enquanto jogo, a filosofia se descaracteriza, tornando-se irrisão de si mesma, pois perde a razão, princípio regulador da produção do saber. Fazendo da filosofia um jogo a serviço da transgressão, Bataille desautoriza a experiência como objeto de saber para explicitar a experiência como um acontecimento que não se diz. Interior ao corpo e exterior à linguagem, a experiência é a própria manifestação do indizível e por isso impossível para o entendimento, só podendo ser referida à distância: "no auge do ser". Desautorizando a experiência como objeto de saber, Bataille afirma-a como autoridade. Afinal, "a experiência, sua autoridade, seu método, não se distingue da contestação". ${ }^{145}$ A experiência não pode ser conhecida porque é contestação do saber e enquanto tal só pode ser contemplada improdutivamente. A contemplação não produz; afirma-se na improdutividade e por isso é soberana em sua atividade: o olhar que contempla é o mesmo que se perde na consumação da experiência e na experiência da consumação, para além do bem e do mal. Deste modo, não servindo à produção, esta "filosofia da contemplação", ou contemplação como filosofia se explicita como um jogo em que as relações entre interdição e transgressão, saber e não-saber, linguagem e silêncio são ambivalentes. Nem tanto ao céu, nem tanto ao mar: sem finalidade produtiva, sem projeto, sem definição, o jogo é fim em si mesmo. Seu único propósito é perpetuar-se soberanamente numa operação que, por um lado, contesta o saber e o trabalho e, por outro, afirma o corpo como consumação de si. Contemplar é não se deixar fixar por conectivos lógicos, dispondo os instrumentos de sensibilia numa relação em que a

\footnotetext{
${ }^{144}$ O.C., X, L'érotisme, p. 269.

${ }^{145}$ O.C., V, L'expérience intérieure, p. 24.
} 
linguagem não prevalece sobre os sentidos do corpo, e, inoperante, se rende à vontade da sorte e à exigência de gasto. No limite, a contemplação é a atividade que autoriza o gasto como operação soberana. Para todo efeito, é uma forma de gasto. Não apenas isto: é a forma pela qual as relações entre linguagem e experiência não se constituem como saber, mas como consumação nas operações soberanas do jogo. Assim, a transgressão aí se evidencia por expor a soberania como vontade de excesso e exigência de gasto. "A contemplação do ser no auge do ser" é a formulação que descreve a experiência como acontecimento de sensibilia, no qual sujeito e objeto se dissolvem na soberania do jogo.

Deste modo, Bataille investe o logos com o ludus, numa operação em que as forças heterogêneas da experiência se afirmam na improdutividade, superando os dispositivos que as interditam, ao mesmo tempo em que, como se verá, os conservam como parte essencial do jogo. Na transgressão jogam as noções de desafio e perigo: "jogo e perigo, risco, sorte, temeridade - em todos estes casos trata-se do mesmo campo de ação, em que alguma coisa 'está em jogo'”, ${ }^{146}$ no qual a superação e o limite jogam como quantidades e a afirmação e a negação como qualidades; do ponto de vista lúdico da transgressão, toda superação reconduz ao limite e toda negação implica a afirmação de ambos na contenda, jogo de cartas marcadas. Por isso, a transgressão não suprime a interdição que a veta, mas a confirma em Bataille, enquanto arrasta a lei em seu movimento, em Blanchot ${ }^{147}$; o interdito não impede o gesto transgressivo, mas o ativa: "a interdição está aí para ser violada". ${ }^{148}$ Neste movimento, algo ao mesmo tempo se supera e se conserva. O interdito constitui a vontade de excesso como transgressão, a esse explicitando do ponto de vista normativo; a transgressão conserva deste o aspecto que desencadeia propriamente o movimento da superação.

Se a transgressão propriamente dita, opondo-se à ignorância do interdito, não tivesse esse caráter limitado, ela seria retorno à violência - à animalidade da violência. De fato, não há nada disso: a transgressão organizada forma juntamente com a interdição um conjunto que define a vida social. A freqüência - e a regularidade - das transgressões não enfraquece a firmeza intangível da interdição, da qual ela é sempre o complemento esperado - como um

\footnotetext{
${ }^{146}$ J.Huizinga, Homo ludens. São Paulo: Perspectiva, 2008, p. 46.

147 L'érotisme, op. cit., p.66.

148 Id., ibid., p. 67.
} 
movimento de diástole completa o da sístole, ou como uma explosão é chamada por uma compressão que a precede. ${ }^{149}$

Se o excesso não tem limites, está fora do jogo da transgressão e da interdição. Do contrário, submetendo-se às limitações do jogo, perderia a soberania, deixando de ser o que é. No jogo, a transgressão explicita a força do excesso, ao qual delimita como índice, enquanto evidencia a si mesma como movimento dual. A rigor, a transgressão difere do excesso por se sujeitar a este esquema, no qual a interdição explicita o pólo oposto. Para Bataille, a cultura fixou seus próprios limites e não comporta a integralidade do excesso, nem pode absorvê-lo continuamente. Um sistema que vive para a produção não privilegia o improdutivo: a parte maldita se constitui como reserva de excesso em si mesma.

\begin{abstract}
A superabundância tem a morte como conseqüência inevitável, somente a estagnação assegura a manutenção da descontinuidade dos seres (do seu isolamento). Essa descontinuidade é um desafio ao movimento que fatalmente derrubará essas barreiras que separa os indivíduos distintos uns dos outros. $A$ vida - o movimento da vida - pede, talvez por um instante, essas barreiras sem as quais nenhuma organização complexa seria possível, nenhuma organização eficaz. Mas a vida é movimento, e nada no movimento está protegido do movimento. ${ }^{150}$
\end{abstract}

Assim, a descontinuidade representa no mundo homogêneo proteção contra a violência do excesso, o que o jogo da transgressão e da interdição assegura. Como diz Bataille, a vida se caracteriza justamente pelo movimento e isso reintroduz a exigência de excesso e o desejo de continuidade. A transgressão é um efeito do excesso gerador que, no entanto, é limitado em seu jogo com a interdição: a cultura assimila e dissimula as formas da violência. No entanto, como diz Bataille, o movimento da vida exige excesso, colocando-se na perspectiva do princípio gerador e da vontade de sorte. Se o jogo da interdição e da transgressão permite que a cultura se conserve, não a deixa de confrontar o movimento que não pode ser contido.

\title{
A sem razão
}

${ }^{149}$ O.C., X, L'érotisme, p.68.

150 O.C., X, L'érotisme, pp. 101-102. 
Viu-se que a vontade de excesso é a força que leva os corpos a se consumarem na experiência, exigindo violência e sem razão. Segundo Bataille, "o erro da filosofia é se afastar da vida", ${ }^{151}$ da qual o excesso é inseparável. Ora,

\begin{abstract}
a filosofia não sai dela mesma, não pode sair da linguagem; ela utiliza a linguagem de tal maneira que o silêncio jamais a sucede. $A$ tal ponto que $o$ momento supremo necessariamente excede a pergunta filosófica. Excede pelo menos na medida em que a filosofia pretende responder à sua própria pergunta. ${ }^{152}$
\end{abstract}

Diante disso, o pensamento se vê num impasse: no domínio da filosofia, ele se envereda pelos meandros do discurso, fechando-se sobre si mesmo, sem alcançar a experiência e sendo excedido por ela; voltado para a experiência, o pensamento se dissolve e mergulha no silêncio. Em suas considerações, Bataille coloca a questão da experiência vinculada à vontade de excesso e à exigência de gasto, em relação a qual "a filosofia não pode se isolar". ${ }^{153}$ Mais do que isso, em sendo a experiência (como no erotismo) a parte problemática do homem, ela é universal, embora continuamente exilada "no ápice do espírito humano". [...] Assim, a "suprema pergunta filosófica coincide [...] com o ápice do erotismo". ${ }^{154}$ Contudo, dada a singularidade da experiência, irredutível aos instrumentos do discurso, o pensamento se volta para o silêncio, onde a contemplação como atividade improdutiva tem efeito.

Em última instância: isso não implica rendição ao não-ser para pensar o ser? Concessão ao irracional, ao não-sentido? Ora, parmenidicamente, ser, pensamento e discurso coincidem. É a razão da unidade, dos princípios de identidade e de não contradição do mundo homogêneo. Na vontade de excesso, porém, essa lógica não vigora, não havendo unidade entre esses três elementos. A experiência heterogênea não se deixa apreender por nenhuma rede conceitual, nem reconhecer por qualquer consciência; se pudesse ser localizada nos termos da linguagem, não ocorreria no pensamento, nem no discurso, mas entre o pensamento e o discurso. Seu

\footnotetext{
151 O.C., X, L'érotisme, p.18.

152 Id., ibid., pp. 268-269.

153 Id., ibid., p. 268.

154 Id., ibid., p. 267.
} 
acontecimento é propriamente a experiência deste entre. É a tônica do pensamento de Bataille: colocar-se na perspectiva invertida do corpo em excesso, do corpo-potência. No extremo: "o que pode um corpo?" Transgredir, consumar-se na experiência, perseverar na improdutividade soberana.

Assim sendo, se o impossível abre um abismo entre a experiência e o discurso, resta ao pensamento e à linguagem colocar-se na perspectiva da contemplação poética. A poesia, como se viu, enquanto atividade improdutiva, vizinha do sacrifício e intensa como o erotismo, responde à vontade de excesso, violentando a linguagem $e$ excedendo a razão. Afinal, como diz Bataille, "soçobrando na filosofia, tento dizer em termos possíveis o que só a poesia, linguagem do impossível, teria o poder de exprimir". ${ }^{155}$ Atividade ambivalente, a poesia exprime sentidos, sem ser discurso. Em Bataille, ao menos em certa concepção, ${ }^{156}$ ela deve ser entendida como "desordem de palavras", ${ }^{157}$ linguagem soberana a qual, investida de forças heterogêneas, excede a ordem do discurso. Voltaremos a isto mais tarde.

O mundo da razão pensa contra a violência, condenando-a no discurso pelo discurso, sobretudo no que diz respeito à herança animal do homem ligada ao sexo e à morte. Tenta-se, assim, de erradicar a violência tornando-a uma referência remota. No entanto, sabe-se que isto não é possível: a violência, no homem, é o retorno da parte maldita. A vida exuberante cobra seu lote: orgias, sacrifícios, enormes gastos de energia. O medo da violência, no extremo, não seria medo da irracionalidade? "A razão é ela própria hostil ao desejo de exceder os limites - que não são unicamente os do ser, mas dela mesma". ${ }^{158}$ Daí talvez o medo de que definitivamente a violência se vingue dos signos e encontre um lugar na razão maior que a razão. Entretanto, dado o caráter absurdo desta, já não se pode mais falar nesses termos: a sem razão do excesso terá feito sentir seus efeitos. Na perspectiva da vontade de excesso, a cultura se defronta com a possibilidade de uma violência ilimitada, quando a sem razão excede o jogo da transgressão e da interdição. Ora, como a parte maldita é a reserva por meio

\footnotetext{
155 O.C., III, L'impossible, p. 515 (notas)

${ }^{156}$ Bataille se refere à poética violenta de Rimbaud, ou mesmo à de Baudelaire, para ilustrar o tipo de poesia que lhe interessa, em oposição ao sentimentalismo, aos "enfados do lirismo", característicos da "bela poesia". V. "L'impossible", id., ibid., p.513 (notas).

157 O.C., VI, Sur Niezsche, p.22.

158 Id., ibid., p.77.
} 
da qual a vontade de excesso põe a vida em movimento, ela força as paixões a uma violência desenfreada, ampliando o poder da transgressão. Tal exposição ao excesso gerador implica um movimento de controle muito mais difícil, que não se faz sem conseqüências; o excesso não se deixa marcar: faz tábua rasa de todo acontecimento para se fazer valer, ele próprio, como um acontecimento inexprimível, extemporâneo, superando o jogo da transgressão e da interdição: pode vir de todos os lados, sem resistência, sem apelos. Ainda assim, o poder de preservação da cultura é tanto que, por vezes, os maiores movimentos de violência acabam sendo assimilados. O sacrifício e a crueldade do canibalismo são exemplos disso:

\begin{abstract}
A crueldade pode derivar em direção ao erotismo e, da mesma maneira, eventualmente o massacre dos prisioneiros pode ter por finalidade 0 canibalismo. Mas o retorno à animalidade, o esquecimento definitivo dos limites, é inconcebivel na guerra. Sempre subsiste uma reserva que afirma um caráter humano de uma violência, no entanto desenfreada. Sedentos de sangue, guerreiros delirantes, contudo, não se massacram mutuamente. Essa regra, que organiza o furor na base, é intangível. Da mesma maneira, a maior parte do tempo, a manutenção da interdição do canibalismo coincide com o desencadeamento das paixões mais inumanas. ${ }^{159}$
\end{abstract}

Aqui, a violência se mostra desenfreada, sinalizando com o "esquecimento definitivo dos limites" e passando pelo "desencadeamento das paixões mais inumanas", ocasiões nas quais a vontade de excesso se explicita como princípio gerador. Então, por algum tempo, nada parece conter o excesso que configura a "transgressão ilimitada", reintroduzindo o movimento da vida como sem razão. Mas neste ponto, já não haveria mais transgressão: todos os limites teriam sido excedidos.

Em seu jogo com a interdição, a transgressão representa o excesso que a cultura demanda como parte maldita. Mas o excesso, por sua força ilimitada, escapa a toda representação: ele simplesmente ocorre como na morte, quando a irreversibilidade de sua força transparece.

Como pensar o que excede a razão? A razão, ela mesma, "é hostil ao desejo de exceder limites - que não são unicamente os do ser, mas os seus próprios". 160 Desdobra-se deste modo a experiência-limite da razão: ela se coloca em relação ao

\footnotetext{
${ }^{159}$ O.C., X, p. 82 [ed. bras. O erotismo [São Paulo: Arx, 2004, p. 124]

160 O.C., VI, Sur Niezsche, p. 24.
} 
que excede o ser e se situa diante da possibilidade do excesso de si mesma: se o pensamento e a linguagem não exprimem o excesso, ambos são, no fundo, impulsionados por ele, sem o quê, a rigor, não há nem pensamento nem linguagem. $\mathrm{O}$ paradoxo pode ser enunciado do seguinte modo: "por definição, o excesso, está fora da razão" ${ }^{161}$ e "o pensamento (a reflexão) só se realiza em nós no excesso". ${ }^{162}$ Ora, se o excesso é o princípio que atua dentro e fora da razão, de sua perspectiva, as categorias "dentro" e "fora" não existem. Excesso é sem razão. A própria linguagem, no dizer de Bataille, "se recusa a expressar a violência", sendo por isto "limitada", mas "não a violência", ${ }^{163}$ já que não há como limitar a vontade de excesso, a qual sempre pode gerar uma força maior. É o princípio do excesso gerador. Experimentando sua vontade como força ativa, os corpos se excedem superando os limites estabelecidos. Na lógica do mundo homogêneo, como se viu, essa desmedida se revela intolerável, pois exceder limites implica algum tipo de morte: do sujeito, da linguagem, da razão. No extremo: o próprio pensamento se ativa como força pela vontade de excesso, superando seus limites:

Mesmo o pensamento (a reflexão) só se realiza em nós no excesso. O que significa a verdade, de fora da representação do excesso, se não vemos o que excede a possibilidade de ver, o que é intolerável ver, como, no êxtase, é intolerável gozar? Se não pensamos o que excede a possibilidade de pensar? ${ }^{164}$

É nesse movimento que a sem razão se mostra como vontade de excesso ao pensamento e o não-saber comunica a experiência. Por isso, a verdade não deve ser alheia ao reconhecimento de que o intolerável não se diz e o primordial do homem é sem lugar no discurso. Excesso de sentido, atrelada à vontade de sorte, a verdade, em Bataille, é sem razão; o passo além, na experiência, é a consumação de si.

Com isso, Bataille não apenas insere o excesso entre as grandes questões da filosofia, como também coloca a filosofia em questão: se o pensamento só se realiza em nós no excesso, a discussão sobre a verdade não pode deixá-lo de fora.

\footnotetext{
${ }^{161}$ O.C., X, L'érotisme, p. 262.

162 O.C., III, "Préface à Madame Edwarda", p.11.

163 O.C., X, L'érotisme, p. 292-293

164 Id., ibid., p.11.
} 
Ainda sobre as relações do excesso com o pensamento, diz Robert Sasso:

se penso o excesso, ele se mostra de-limitado, recortado pelo pensamento: ele não é mais excesso. Entretanto, se o pensamento excede a noção de "excesso", há excesso ao menos no pensamento. ${ }^{165}$

O paradoxal no excesso é que, por um lado, ele não se distingue da força que faz pensar, por outro, não pode ser ele próprio objeto do pensamento que anima, já que só existe enquanto vontade irredutível às possibilidades da razão: o excesso é "outro nome para o impossível". 166

Deste modo, em Bataille, há esse movimento que desloca a leitura para um centro vertiginoso, no qual pensar não é possível sem levar em conta a experiência que coloca o pensamento em questão. O limite do pensamento é o da experiência mesma de pensar na perspectiva da consumação de si. Por isso, tanto em Bataille, como em Sade, o corpo é a via da consumação que a vontade de excesso explicita:

o excesso mesmo é o fundamento do espírito do homem. Este dado é concebido por este espírito, é concebido em seus limites. A soma das dores que um corpo humano suporta excederia o excesso que o espírito concebe? Creio que sim. Em teoria, o espírito concebe o excesso ilimitado. Mas de que maneira? Eu lhe rememoro um excesso que ele jamais poderia suportar. ${ }^{167}$

Se de fato o excesso pode ser representado no espírito, ele só pode ser comprovado no extremo do possível, quando se mostra intolerável à sensibilidade física. Assim, a imaginação pode conceber o maior excesso possível, mas somente a experiência do corpo acusa o excesso como desmedida, hybris. A linguagem por certo comporta uma infinidade de excessos, tão imensos quanto uma imaginação é capaz de conceber. Há, sem dúvida, uma desmedida simbólica que demonstra o poder da linguagem na cultura: o olhar construído ao longo da história e de suas representações toma sem esforço como real o plano abstrato dos signos. Tais excessos, não sendo exatamente inócuos, são formas simbólicas de gasto que a operação soberana da linguagem explicita: excesso de sentido, excesso de signos. Sade, sem dúvida, ataca as instituições de seu

\footnotetext{
${ }^{165}$ Georges Bataille: le système du non-savoir, op., cit., p. 178.

${ }^{166}$ Id., ibid., p. 179.

167 O.C., XII, «Le pur bonheur », p. 486.
} 
tempo com a pletora da linguagem, sua violência, seu ódio; no entanto, ele mesmo assinala os limites deste excesso: todo grande libertino persegue um gozo impossível, por meio do excesso mais violento. O monge Séverin queixa-se, particularmente, da desproporção entre o que é do pensamento e o que é do corpo:

"tudo está aquém de meus pensamentos e nada satisfaz meus desejos" [...] "Oh! Há séculos encontro-me no mesmo ponto, responde Jérôme, e mais de vinte anos só me excito com a ideia de um crime superior a todos que o homem possa fazer no mundo..."

"Tudo o que fazemos aqui é a mera imagem do que gostaríamos de poder fazer". 168

A libertinagem é praticada na perspectiva de um gozo ideal, promessa da imaginação. O gozo ideal, em Sade, é a imagem da continuidade plena entre a vontade de excesso e sua possibilidade real. Este gozo idealizado à exaustão é o impossível. Mas a imaginação, que viabiliza o excesso e dá vazão aos gastos simbólicos (efeitos da operação soberana da linguagem), jamais exprime a integralidade da experiência corporal. Ora, o limite do excesso, na linguagem, não corresponde ao do corpo, na experiência, em que propriamente o excesso é intolerável, leia-se: indizível: o corpo fala mais forte, pois sua sem razão de ser é sensibilia. Compreende-se, nesta perspectiva, o comentário de Bataille ao leitor sadiano: "se admiramos Sade, edulcoramos seu pensamento", ${ }^{169}$ no qual a relação com a linguagem atenua o excesso que é intolerável para o corpo. Tal formulação desnuda a armação simbólica dos signos, de grande eficiência e comodidade para a cultura, a qual, deste modo transfere para o plano da linguagem o que figura como intolerável no âmbito da vida concreta. Não será por fatores como este que a literatura se mostra tão poderosa?

Assim, para Bataille, é preciso "abrir as noções para além delas mesmas". O que seria do pensamento se não houvesse nele mesmo "algo que o força a pensar": ${ }^{170} 0$ pensamento impulsionado pelo excesso a despeito da consciência, ou, o que é pior: da

\footnotetext{
${ }^{168}$ Sade, La nouvelle Justine, op., cit., vol. 1, p. 297.

${ }^{169}$ O.C., X, L'érotisme, p. 178.

170 G. Deleuze, Diferença e repetição. São Paulo: Graal, 2006, p. 203.
} 
"má consciência", esta "profunda doença", nas palavras de Nietzsche? ${ }^{171}$ Há, no entanto, que se aproximar o pensamento da experiência, mudando, não somente a direção do leme, mas também o leme.

Peço desculpas por acrescentar aqui que esta definição do ser e do excesso não se pode fundamentar filosoficamente, já que o excesso excede o fundamento: o excesso é aquilo que faz com que o ser seja, antes de qualquer outra coisa, algo que escapa a todos os limites: esses limites permitem-nos falar (eu também falo, mas falando não esqueço que a fala não só me escapará, como está me escapando). ${ }^{172}$

O pensamento do excesso é sua própria experiência-limite. Não se pode pensar o que excede o pensamento, pois nesse movimento o pensamento se consuma. A vontade de excesso manifesta o impossível e afirma o não-saber, a verdade da consumação: "a mão que escreve é moribunda”."173

Por isso, em Bataille, não se trata de um pensamento sobre o corpo, com o dispositivo do discurso girando em torno de seu eixo, mas de um pensamento do corpo, assimilando a linguagem à vontade de excesso. Assim, todo o problema acerca da experiência e da razão diz respeito ao caráter paradoxal da linguagem:

O que seríamos sem a linguagem? Ela fez de nós o que somos. Somente ela revela, no limite, o momento soberano em que não há mais curso. Mas, no fim, aquele que fala confessa sua impotência. ${ }^{174}$

A linguagem nos coloca no limite. O momento soberano da experiência não se diz. A experiência é sensibilia, sua única autoridade; quem está "no auge do ser" em "contemplação silenciosa" está fora do discurso: contestação do saber, a experiência é a verdade do corpo. Neste caso, o silêncio fala mais que a linguagem.

\footnotetext{
${ }^{171}$ Nietzsche, Genealogia da moral, op. cit., p. 72.

172 O.C., III, «Préface à madame Edwarda», p.12 (nota).

${ }^{173}$ Id., ibid.

${ }^{174}$ O.C., X, L'érotisme, p. 270.
} 


\section{IV- O CORPO EM EXCESSO}

\section{Experiência, comunicação e êxtase}

A experiência, em Bataille, não é conhecimento, nem uma técnica recorrente que se adquire e se pratica, mas o acontecimento no qual o corpo se coloca na via do excesso e da consumação de si. Em princípio, a experiência se caracteriza como ocorrência interior ao sujeito, o qual, ao consumar-se, desativa o campo de ação da consciência, afirmando o corpo como pura perda. Interior ao sujeito e exterior ao saber, a experiência constitui-se como margem na qual uma operação de intimidade evanescente se faz no extremo do possível. O que ela manifesta não vem à luz no discurso, deixando os sentidos suspensos enquanto vontade de excesso do corpo: a experiência interior é o êxtase.

Como pensar a experiência? A dificuldade, como sempre em Bataille, é tratar de um acontecimento heterogêneo ao discurso e no discurso, procedendo "à maneira do filósofo". Por isso, a experiência não pode ser "objeto de uma ciência", só se deixando entender como acontecimento vital dos poderes do corpo e da contestação de qualquer saber: "vivo de experiência sensível e não de explicação lógica". ${ }^{175} \mathrm{Na}$ experiência, portanto, o corpo mergulha na ignorância para se afirmar como sensibilia. Condição de soberania, a ignorância é atributo necessário do corpo em excesso.

Essa noção de experiência se aproxima da teologia negativa ou mística, como em Teresa de Ávila e João da Cruz, nos quais o alheamento da consciência leva ao êxtase. Contudo, Bataille adverte:

Entendo por experiência interior o que geralmente chamam de experiência mística: os estados de êxtase, de arrebatamento, ao menos de emoção meditada. Mas penso menos na experiência confessional, à qual foi preciso ater-se até aqui, do que numa experiência nua, livre de amarras, mesmo de origem, a qualquer confissão que seja. É por isso que não gosto da palavra mística. ${ }^{176}$

\footnotetext{
175 O.C. V, L'expérience intérieure, p. 45.

${ }^{176}$ Id., ibid., p. 15.
} 
A diferença entre as concepções de Bataille e as dos místicos refere-se ao modo como cada um descreve a experiência interior. Ao introduzir a questão, Bataille evita a linguagem confessional, diferenciando-se da ótica mística, já que a ele importa salientar o que na experiência representam o gozo e a perda dos sentidos na consumação do sujeito e seus efeitos, como a angústia e a fenda, fêlure, e não o sentimento de transcendência, enquanto ascese, em direção a Deus. A experiência, em Bataille, é uma operação do corpo e enquanto tal só se efetua na imanência, evidenciando o gasto como forma de potência, diferentemente do que acontece entre os místicos, em quem o êxtase implica a comunhão gozosa em Deus e o sentimento salvífico.

Nesse sentido, como em outras modalidades improdutivas de consumação do sujeito e de comunicação do corpo, como o erotismo, o sacrifício e a poesia, na experiência, diz Bataille, "eu não sou, tu não és, nestes vastos fluxos de coisas senão uma suspensão (point d'arrêt), favorável ao jorro". ${ }^{177}$ Nessa dimensão que suspende a razão homogênea, colocando o corpo na via improdutiva da heterogeneidade, o point d'arrêt expressa o desligamento da consciência. O corpo se afirma como vontade de excesso, colocando os sentidos em suspensão, o que não se faz sem perdas: do sujeito, da linguagem, da razão. Tais perdas, no entanto, se atestam a impotência da razão, afirmam o corpo enquanto sensibilia, desembocando em seu acontecimento maior: o êxtase. Este não procede como na mística, no sentido de "espiritualizar o domínio da sexualidade para elevá-lo ao nível das experiências etéreas", ${ }^{178}$ mas afirma o corpo no gozo e na pura perda ou despesa: "só nos desnudamos completamente, quando nos dirigimos, sem trapacear, ao desconhecido". ${ }^{179}$

Manifestação do não-saber, a experiência não faz sentido, pois não revela nada ao anular os projetos de salvação. Diferindo tanto da relação sujeito-objeto que está na base do conhecimento, quanto da ligação do fiel com Deus incensada pela crença, a experiência em Bataille implica operações de outra natureza: "O NÃO-SABER DESNUDA" [...] "O NÃO-SABER COMUNICA O ÊXTASE. O não-saber é antes de tudo

\footnotetext{
${ }^{177}$ Id., ibid., p. 112.

178 L'érotisme, op., cit., p. 240.

179 L'expérience intérieure, op., cit., p.17.
} 
ANGÚSTIA". ${ }^{180}$ Desnudamento, angústia e êxtase, portanto, não são fatos de saber ou discurso, mas estados de sensibilia que se explicitam numa cadeia de efeitos: súplica, perda da consciência, arrebatamento, gozo erótico, sensação de morte.

Assim, ao contrário da experiência mística dos santos, como Teresa de Ávila e João da Cruz, a experiência em Bataille leva ao nada, cuja sensação, portanto, não se distingue do gozo dos sentidos e da morte do sujeito. Na experiência, os estados de intensidade se fundem, vedando o corpo soberano os saberes do sujeito.

Nesse ponto, em Bataille, a experiência corporal se aproxima da poética, entendendo-se a segunda como análoga à primeira. Como a experiência é consumação, "o poético é o familiar dissolvendo-se no estranho e nós mesmos com ele". ${ }^{181}$ Igualmente, tanto a efusão corporal (erótica, extática), quanto a poética, são experiências de consumação que, soberanas, operam com a perda (do sujeito, do sentido, do saber), visando à continuidade. A poesia diferencia-se das outras formas de despesa, por ser linguagem. Por isso, para Bataille, a poesia só interessa como forma de contestação, reafirmando, com a virulência das palavras, o que ela própria implica como atividade improdutiva: seus sentidos não contam, mas a experiência que excede os sentidos. A poesia é uma operação soberana, mas não pode exprimir a experiência porque ela própria é experiência: "vizinha do sacrifício", comunica o não-saber, afirmando-se como vontade de excesso e consumação.

Bataille descreve a experiência interior como "uma viagem ao término do possível no homem": ${ }^{182}$ o esgotamento das possibilidades abre-se para o impossível. Não tendo outra finalidade ou sentido além da consumação de si, a experiência é sua própria autoridade. Assim, os termos: soberania, êxtase, comunicação, autoridade, nãosaber e contestação se referem uns aos outros, explicitando o corpo em excesso na experiência: "contesto em nome da contestação que é a própria experiência (a vontade de ir ao extremo do possível). A experiência, sua autoridade, seu método não se distinguem da contestação". ${ }^{183}$ O método não é outro senão o do gasto na soberania, através da qual a experiência opera excedendo os saberes e as interdições do mundo

\footnotetext{
${ }^{180}$ Id., ibid., p. 66.

181 L'érotisme, op., cit. p. 17.

182 L'expérience intérieure, op., cit., p. 19.

183 Id., ibid., p. 24.
} 
homogêneo, ao mesmo tempo em que contesta o que no homem se constitui como presença, o "em si" e o "para si" da consciência, levando o corpo ao extremo do possível, onde os sentidos se suspendem.

\begin{abstract}
A vida, em sua essência, é um excesso; ela é a prodigalidade da vida. Sem limites, ela esgota suas forças e seus recursos; sem limites, ela aniquila o que criou. A multidão de seres vivos é passiva nesse movimento. No extremo, porém, queremos resolutamente o que coloca nossa vida em perigo. ${ }^{184}$
\end{abstract}

Retirado de seu domínio conhecido e sem razão, o corpo em excesso está aberto para a comunicação com outros, no erotismo, na festa, no sacrifício, no êxtase. Tal corpo consiste na reação de forças heterogêneas à razão homogênea. É nesse ponto que ele se desnuda e perde o rumo, arrebatado pelo movimento vertiginoso da consumação. Portanto, a experiência, em Bataille, deve ser entendida a partir de sua etimologia latina: experiri tem a mesma raiz que periculum, perigo: a experiência é o acontecimento que coloca o corpo na via do excesso, até o extremo do possível, o que não se faz sem risco. Daí seu caráter dramático: "se não soubéssemos dramatizar, não poderíamos sair de nós mesmos", ${ }^{185}$ o que, aliás, explicita a experiência como acontecimento-limite e comunicação no sentido forte da palavra. ${ }^{186}$

A comunicação forte abre a experiência do corpo em excesso para outros corpos, mergulhando o sujeito em pura perda. Arrebatado do plano da consciência, em que se forjam seus limites, sua "integridade" e do mundo homogêneo, em que se relaciona com as coisas (objetos), com base na utilidade e na lógica do desempenho, o sujeito se dissolve na experiência da consumação de si (êxtase), do corpo coletivo (erotismo, festa, sacrifício) e da despesa simbólica (poesia).

Proponho tomar como uma lei que os seres humanos só se unem entre si por dilaceramentos ou feridas: esta noção possui em si mesma certa força lógica. Se elementos se compõem para formar o conjunto, isto pode facilmente se produzir quando cada um deles perde por um rasgo de sua integridade uma parte de seu ser próprio em proveito do ser comunal. ${ }^{187}$

\footnotetext{
${ }^{184}$ L'érotisme, op., cit., p. 88.

185 L'expérience intérieure, op., cit., p. 23.

${ }^{186} \mathrm{Em}$ Bataille, a comunicação forte diz respeito aos seres que se põem em jogo numa experiência de limites. É a comunicação dos corpos implicando a vontade de excesso; a comunicação fraca restringe-se à vida social regulada pelas normas de convivência e conveniência social, pautadas pela ética de controle.

187 O.C., II, p. 370.
} 
Aqui, os termos rasgo ou dilaceramento, déchirure e ferida, blessure, são figuras que expressam a comunicação dos corpos em excesso na experiência interior: o que se comunica é a própria experiência da consumação, sem distinção de gozo e perda: "a comunicação ata [os corpos] pelas feridas, cuja unidade e integridade se dissipam na febre". ${ }^{188}$ É nesse ponto que a fusão erótica dos corpos, liberados da finalidade reprodutiva, revela os efeitos da comunicação forte: falta, angústia, sensação de morte do sujeito. Afinal, [...] "a 'comunicação' só tem lugar entre dois seres postos em jogo dilacerados, ambos suspensos e inclinados por cima de seu nada. ${ }^{189}$ A comunicação implica, assim, uma comunidade de seres afins, que na relação com o outro e na consumação de si, afirmam a soberania dos corpos em excesso.

Tais acontecimentos da vida social e psíquica não são possíveis sem dramatização. O drama, em Bataille, é a operação na qual o corpo se afirma e o sujeito se perde na consumação, cume da experiência interior: "só atingimos os estados de êxtase ou de arrebatamento, dramatizando a existência em geral", ${ }^{190}$ ou seja, quando o corpo se coloca no extremo do possível, caracterizando a experiência. Também no sacrifício, o momento em que a vítima é imolada marca o extremo da dramatização, ${ }^{191}$ pois os que sacrificam se ligam ao corpo excedido pela consumação, estabelecendo a continuidade, a qual representa o ápice do drama: quando todos os corpos, esvaziados da consciência (seu elo com o mundo homogêneo), se fundem na sem razão do excesso em gasto sem reservas.

Paradoxal em si mesma, a experiência consiste na única resposta para o homem que, no fundo, é uma "súplica sem resposta". Eis o ponto em que a autoridade da experiência se expia, como afirma Blanchot. Pois, para Bataille, a experiência interior não tem finalidade nem autoridade que a justifiquem, restando um vazio nesta afirmação: em conversa com Blanchot, este teria dito a Bataille que "finalidade" e "autoridade" são exigências do pensamento discursivo. Mas diante da insistência de Bataille em saber como então seria possível uma experiência sem autoridade, Blanchot

\footnotetext{
188 Id., ibid., p. 369.

189 O.C., VI, Sur Nietzsche, p. 45

190 L'expérience intérieure, op., cit., p. 22.

191 Id., ibid., p. 23.
} 
argumentara que a experiência é a própria autoridade, acrescentando que é por causa desta que aquela deve ser expiada. ${ }^{192}$ Assim, a experiência é o acontecimento no qual o corpo se livra da própria autoridade, purificando-se dela e compensando-se do fato de que, afinal, é essa mesma autoridade que torna a experiência possível; leva-se, aqui, em conta que a expiação da autoridade é o que intensifica a experiência na consumação: se houvesse uma razão para o excesso, ela seria desmedida e sem razão.

Finalmente, a experiência é dramatização pelo movimento da sorte, chance, operadora da vontade de excesso, a qual, desabrigando a razão homogênea, expõe o corpo ao perigo das forças heterogêneas do não-saber, introdutoras de violência e ignorância, a dupla-face da irracionalidade.

\footnotetext{
Na medida em que podem (é uma questão - quantitativa - de força), os homens buscam as maiores perdas e os maiores perigos. Acreditamos facilmente no contrário, porque eles, com freqüência, têm pouca força. Tão logo a força os favoreça, querem imediatamente se dispensar e se expor ao perigo. Quem quer que tenha força e os meios, se entrega a contínuas despesas e se expõe incessantemente ao perigo. ${ }^{193}$
}

A experiência é este acontecimento que desfaz a razão homogênea e tudo aquilo que a consciência constitui como presença de sua relação com o mundo. A dissolução do sujeito é o primeiro efeito da interiorização da vontade de excesso: "o objeto da experiência é, antes, a projeção de uma perda de si dramática”. 194

Outro efeito é a comunicação dos corpos, no erotismo, o qual, em Bataille, não se realiza sem alguma forma de violência: a experiência erótica é fusão dos corpos visando à superação da angústia e da falta, próprias de um ser que vive sob o princípio de insuficiência. Ainda que a experiência interior em Bataille se refira mais propriamente à efusão extática, a contestação do saber, a perda da consciência, o sentimento de continuidade e o gozo da consumação de si também estão presentes no erotismo e no sacrifício, já que as atividades improdutivas são similares entre si. Deste modo, o "si mesmo", [...] "não é o sujeito se isolando do mundo, mas um lugar de comunicação, de

\footnotetext{
${ }^{192}$ Id., ibid., p. 67.

193 O.C., X, L'érotisme, p.123

194 O.C., V, L'expérience intérieure, p.137.
} 
fusão do sujeito e do objeto". ${ }^{195}$ A experiência em Bataille se refere, portanto, a um acontecimento singular que, no limite, abole a fronteira entre o interior e o exterior, afirmando o corpo como vontade de excesso na continuidade.

Comunicação da insuficiência do ser (desejo, angústia, falta, ferida) e contestação da razão homogênea (consciência, discurso, saber), a experiência manifesta a vontade de excesso afirmando sua autoridade até expiá-la na consumação, donde o significado desta frase de Bataille: "o não-saber comunica o êxtase". ${ }^{196}$ Culminando a experiência, o êxtase implica, simultaneamente, o gozo da autoridade morrendo, a dor dessa perda e sua catarse. Por isso, Foucault se refere ao acontecimento singular da experiência como "alguma coisa da qual se sai a si mesmo transformado" ${ }^{197}$ Eis porque, para todo efeito, a experiência põe o ser em questão. Se o método da experiência, por certo, não é o do saber filosófico, nem sua autoridade deriva do trabalho da argumentação e de seu produto mais sofisticado, o conceito, ambos realizam a experiência como contestação: o que ela, enquanto sensibilia, contesta, é a própria razão, ao passo que esta, recusa, enquanto sapientia, a soberania do corpo em excesso.

Para Bataille, o homem está "à procura de um ápice" e jamais pode suprir a falta que seu ser manifesta, porque a experiência é um acontecimento excepcional, no extremo do possível, mas logo sucedido por um movimento que recompõe a ordem das coisas à luz da razão homogênea. O homem se lembra (melhor dizendo: "se conscientiza") de que é um ser descontínuo e a continuidade, afinal, não passa de "um sentimento" ${ }^{198}$, efeito da vontade de excesso. Mas esta constatação também é superada por outra exigência de excesso e demanda de gasto: o não-saber coloca de novo o indivíduo sob o point d'arrêt da experiência. No âmbito da economia geral, como se viu, isto acontece porque a atividade produtiva sempre gera um excedente, que por sua vez implica a heterogeneidade. Retoma-se, de novo, o jogo da transgressão e da interdição, e nessa ambivalência, nesse duplo movimento em que algo ao mesmo tempo se supera e se conserva, a cultura se reproduz a si mesma.

\footnotetext{
195 Id., ibid., p. 21.

${ }^{196}$ Id., ibid., p. 143

${ }^{197}$ Cit. por M. Jay, "Limites de l'expérience-limite: Bataille et Foucault", op., cit., p. 40.

198 L'érotisme, op., cit., p. 21.
} 
Por isso mesmo, o homem, em Bataille, sem garantias, sem esperança, sem Deus, "é uma súplica sem resposta", mas que se manifesta na experiência, contrapondo-se ao mundo da razão homogênea: reação que não deixa de ser uma forma de resposta, mas que se esgota em si mesma, reafirmando este comentário de Bataille sobre o êxtase: "nasce do não-saber mesmo e não desemboca em nada a não ser solidão e riso". 199

\section{O mais-corpo e o ser-menos}

Enquanto o corpo é a sem razão da experiência e a constitui como sensibilia, o ser, para Bataille, não está em parte alguma, pois "é aquilo que falta". Na experiência, o corpo está em toda parte e o ser em nenhuma, já que este último não pode ser posicionado historicamente numa situação concreta, à maneira dos filósofos da existência, Sartre à frente. O ser, em Bataille, não tem qualquer determinação, sendo deslocado do eixo homogeneizante do saber pela vontade de excesso e pela exigência de gasto sem reservas. Agente e joguete da sorte, chance, o corpo soberano coloca a existência em questão, entregando-se ao jogo da vida, em que pode tanto exceder como ser excedido.

Excedendo a natureza no jogo, é indiferente que eu a exceda ou que ela mesma se exceda em mim (ela pode ser inteiramente excesso dela própria, mas, no tempo, o excesso se insere por fim na ordem das coisas (eu morreria neste momento aí). ${ }^{200}$

Em Bataille, vontade de excesso e sem razão, o corpo é sempre mais e o ser é sempre menos: o que está em falta, não se encontrando na linguagem, em parte alguma: "o ser é inalcançável". 201 O corpo em excesso, ao contrário, emerge da experiência enquanto parte maldita e se explicita enquanto linguagem soberana na poesia. Reagindo à razão homogênea, na experiência, a vontade de excesso participa tanto do corpo quanto da

\footnotetext{
199 L'expérience intérieure", op., cit., p.169.

${ }^{200}$ L'érotisme, op., cit., p. 219.

201 L'expérience intérieure, op., cit., p. 98.
} 
linguagem, na qual o ser é posto em questão. Deste modo, as experiências heterogêneas do erotismo, do sacrifício, da poesia, do êxtase acontecem no buraco do ser, caracterizado como fenda, fêlure no sujeito, ao passo que a soberania consiste justamente na afirmação do corpo "à procura do ápice", visando à consumação de si.

$\mathrm{Na}$ experiência interior, a angústia caracteriza a falta do ser-menos (aquilo que faz rir), constituindo-se como princípio para o êxtase: em Bataille, a "vontade de ápice" nasce de um princípio de insuficiência, estado de falta ocasionado pelo mundo homogêneo, razão pela qual todo discurso também é insuficiente. Assim, excedendo o ser em falta e seu discurso impotente, o mais-corpo se abre para o não-saber da experiência, na qual se afirma, soberanamente, na intensidade da vida e na consumação da morte, expressando-se por meio de figuras hiperbólicas: o acéfalo, o terrível, o morto proliferante.

\section{Acefalia e morte}

O que acontece quando o corpo improdutivo cede à vontade de excesso e se abre para a experiência? Ele se torna soberano, isto é, desvia-se da produção e se consuma sob o princípio da despesa. No universo de Bataille, este corpo se expressa pela figura do "acéfalo".

Ilustrando o primeiro número da revista Acéphale, André Masson retrata um homem decapitado (a cabeça foi enxertada no sexo), trazendo em uma mão um coração em chamas e na outra uma espada: é o emblema do corpo em excesso. Michel Surya comenta esta ilustração:

\footnotetext{
Um homem decapitado (Acéphale é aquele que despreza tão profundamente o espírito e a razão que de bom grado se representa subtraído de seu duplo império), entregue aos livres jogos de sua paixão de estar no mundo, não tem mais Deus nem razão; ele não é mais exatamente um homem, nem exatamente um Deus, mas talvez tenha mais vantagem do que um e outro. Certamente ele é mais do que qualquer outro eu, um monstro híbrido, um monstro feliz. ${ }^{202}$
}

\footnotetext{
${ }^{202}$ M. Surya, Georges Bataille, la mort à l'oeuvre, op., cit., p. 287.
} 
Será o acéfalo um monstro que o sonho da razão produziu? Regulada pelo princípio do desempenho, a razão homogênea é aquela de quem se exige ter "os pés no chão" e "a cabeça no lugar", enfim, sempre em alerta contra os perigos do excesso, das condutas soberanas, de toda efusão dispendiosa de natureza heterogênea. A acefalia é a conduta dos que se entregam "aos livres jogos da paixão de estar no mundo", sem "Deus" nem "razão" e que gera seus signos:

quando tenho o rosto injetado de sangue, ele fica vermelho e obsceno.

Ao mesmo tempo, por mórbidos reflexos, ele revela a ereção sangrenta e uma sede ávida de impudor e de criminosa lascívia. ${ }^{203}$

O corpo em excesso se exibe com "o rosto injetado de sangue", em "ereção sangrenta", culminando em "criminosa lascívia". O acéfalo é a figura hiperbólica das condutas soberanas em Bataille, expressando a sem razão do corpo em excesso, ligando o erotismo à morte.

Ora, nesses termos, a violência do erotismo é uma reação ao mundo organizado da racionalidade e do trabalho, o qual procura, pelo mecanismo das interdições, regular as práticas sexuais. Assim, "o objeto fundamental das interdições é a violência". ${ }^{204}$ É esta oposição entre a razão e a violência que suscita a interpretação antropológica de que o mundo profano representa o desenvolvimento da primeira e o mundo sagrado corresponde à vontade de excesso da segunda. Com relação ao homem primitivo, Bataille observa:

A razão não dominava todo o seu pensamento, mas ela o dominava na operação do trabalho a tal ponto que um primitivo pôde conceber, sem formulálo, um mundo do trabalho ou da razão, ao qual se opunha um mundo da violência. A morte significa, certamente, uma diferença tanto quanto uma desordem na organização do trabalho: o primitivo podia sentir que a ordenação do trabalho Ihe pertencia, enquanto a desordem da morte o superava, fazendo de seus esforços um non sense. O movimento do trabalho, a operação da razão, serviam-lhe, enquanto a desordem, o movimento da violência, arruinavam o próprio ser, que é o fim das obras úteis. O homem, ao identificarse com a ordenação do trabalho, separava-se nessas condições da violência, que atuava no sentido contrário. ${ }^{205}$

\footnotetext{
${ }^{203}$ O.C., I, L'anus solaire, p. 85.

${ }^{204}$ O.C., X, L'érotisme, p. 45.

205 Id., ibid., p. 48.
} 
Violência e ruína se associam, assim, ao movimento do gasto desenfreado, escapando ao controle racional. Tanto o erotismo quanto a morte, põem a vida interior em questão. Mas a morte introduz uma diferença: ela se expressa vivamente como superação de toda ordem, revelando o absurdo de um mundo que se projeta calcado na razão e no trabalho. O acéfalo exibe seu corpo em desordem como um triunfo da vontade de excesso. As condutas soberanas da experiência são operações que caracterizam a despesa nas efusões erótica, extática, poética, explicitando a consumação. No extremo desse movimento, a singularidade da morte confere ao gasto uma fisionomia: o cadáver em decomposição é a imagem viva da atividade improdutiva sob o princípio da despesa. Visto com repugnância pela cultura, que procura esconder seus vestígios, o cadáver representa a soberania da morte e, enquanto tal, uma ameaça de contágio, tanto de sua violência, quanto de seu terror.

\begin{abstract}
O morto é um perigo para aqueles que ficam: eles devem enterrá-lo menos para protegê-lo e mais para se protegerem deste 'contágio'. Freqüentemente, a ideia de 'contágio' se liga à decomposição do cadáver no qual se vê uma força temível, agressiva. A desordem, biologicamente a podridão futura da mesma maneira que o cadáver fresco é a imagem do destino, traz nela mesma uma ameaça. Não acreditamos mais na magia contagiosa, mas quem entre nós poderia dizer que não tremeria diante da visão de um cadáver coberto de vermes?
\end{abstract}

Chega-se, aqui, ao terrível, cujo sentido ultrapassa o que a razão homogênea tolera e que por isso se resguarda por trás de fronteiras simbólicas. Mas o intolerável aos sentidos é também o que leva o corpo a exceder limites, colocando-o na condição soberana do demasiado humano.

\title{
O fim da beleza
}

"O horror é o princípio de meu desejo", diz Bataille. ${ }^{207}$ Releia-se a frase à luz destas linhas da primeira das Elegias de Duíno, de Rilke, acerca da beleza:

\footnotetext{
${ }^{206}$ Id., ibid., p. 49..

207 O.C., X, L'érotisme, p. 62.
} 
Wer, wenn ich schriee, hörte mich denn aus der Engel

Ordnungen? Und gesetzt selbst, es nähme

einer mich plötzlich ans Herz: ich verging von seinen

stärkeren Dasein. Denn das Schöne ist nichts

als des Schrecklichen Anfang, den wir noch grade ertragen,

und wir bewundern es so, weil es gelassen verschmäht,

uns zu zerstören. Ein jeder Engel ist schrecklich. ${ }^{208}$

Neste fragmento do poema, o belo surge como uma medida ou, literalmente, como "o começo do terrível" (Schrecklichen Anfang), que ainda se tolera. Trata-se, portanto, de uma relação entre o limite e o excesso, cujo fiel da balança é justamente a beleza. Há algo de terrível na beleza, mas o movimento que o desencadeia está detido na estrutura mesma do belo, isto é, enquanto este não é devassado, aniquilado pela legião de anjos que compõem o movimento terrífico, mantendo-se dentro de seu próprio limite, ainda que sob tensão. A beleza é o que inspira o terror, mas também aquilo que o limita, levando-se em conta que o terror se anuncia nela mesma. Este frágil equilíbrio é rompido, ${ }^{209}$ expondo o belo corpo à ação das forças degenerativas do tempo e dos fatores em geral ligados a este, como o envelhecimento, as doenças, etc., representados, no poema, pela legião de anjos terríveis.

É uma alegoria, pois, o que se tem diante dos olhos: a da vida exuberante que se degenera. Os belos corpos são arruinados porque pertencem ao reino dos que vivem sob a lei imanente do gasto. A beleza é o sintoma da ruína e seu significado só se completa nessa tensão da imagem que ameaça deixar de ser o que é. Colocar-se nesta perspectiva é comprovar a força destruidora do belo investida da potência do excesso, tanto para destruir aqueles que de algum modo se relacionam com ele, quanto para aniquilar-se, consumando-se como efeito da própria exuberância. Em ambos os casos, o fator imprevisível da sorte, chance, atua como vontade de excesso. A legião de forças se apodera do corpo, arruinando-o ao mesmo tempo em que se expressa vivamente

\footnotetext{
208 "Quem, se eu gritasse, entre as legiões dos Anjos / me ouviria? E mesmo que um deles me tomasse / inesperadamente em seu coração, aniquilar-me-ia / sua existência demasiado forte. Pois que é o Belo / senão o grau do Terrível que ainda suportamos / e que admiramos porque, impassível, desdenha / destruir-nos? Todo Anjo é terrível". R.M. Rilke, Elegias de Duíno (trad.: Dora Ferreira da Silva). São Paulo: Globo, 2001, pp. 16-17.

${ }^{209}$ A beleza enquanto potência é "força de resistência", na expressão de Klossowski a respeito de Nietzsche. V. P. Klossowski, op. cit., p. 109. Mas se há um equilíbrio de forças (em nosso caso, entre a beleza e o terror), ele terá de ser rompido, já que a potência é potência justamente porque pode expandir-se amplamente. No poema de Rilke, em consonância com o pensamento de Bataille, a potência da beleza não engendra só o mesmo, vale dizer, a própria beleza, mas degenera em terror como sua diferença imediata, por efeito de atualização radical.
} 
como efeito da experiência da consumação: os anjos de Rilke encarnam a vontade de excesso no trânsito da beleza ao horror.

Recue-se a Baudelaire para um breve exame da dualidade do belo: um elemento eterno, invariável e um elemento relativo, efêmero, o integram, conforme as manifestações da época, no que possam significar a moda, a moral, a paixão. ${ }^{210}$ Se o significado da beleza depende do equilíbrio entre ambos, é possível identificar em certa produção literária e artística, sobretudo moderna (Baudelaire inclusive), a preponderância do último, nesta percepção de que o elemento relativo introduz um movimento incontrolável, antecipado pela sensação do terror. Os efeitos imediatos desse movimento nos corpos são por demais conhecidos: a degenerescência, a corrupção, a ruína, a podridão, enfim, aquilo que, nos termos da economia geral proposta por Bataille, deriva do princípio de gasto. Assim, a beleza comunica algo que só faz sentido enquanto por ele é ultrapassada. O que ela é, nesse trânsito, não se fixa, pois seu sentido emerge justamente do ponto de saturação, o da exuberância máxima, quando sua forma homogênea começa a desfazer-se sob o impacto das forças heterogêneas que desvirtuam o aspecto ideal, deslocando o sentido da beleza para o topos do horror. O belo é a ocasião extrema desse efeito, como que presa por um tênue fio, mas claríssimo, significando o máximo que o efêmero pode dar: o belo em toda exuberância, constituído e limitado pelo tempo, concedendo à vida seu valor primordial. Deste modo, o terrível que se anuncia na beleza e começa a transfigurá-la explicita a vontade de excesso que reina na natureza e no homem. $O$ belo restringe-se a este último olhar sobre a imagem que o detém exatamente no ponto em que o derradeiro instante é também o mais intenso e afirmativo da plenitude do ser, correspondendo ao que na imagem ainda é tolerável: "o começo do terror", pois no momento seguinte ele já se mostra tomado pelas forças heterogêneas da corrupção e, do ponto de vista do mundo homogêneo, sua imagem se torna a expressão convincente de todo mal.

Em Bataille, a explicação é que os corpos se definem pela exigência de dispêndio e pela vontade de excesso e que por isso mesmo buscam suprir a falta de ser nas experiências do erotismo, do sacrifício, da poesia, do êxtase. Ao corpo, não resta alternativa senão a consumação de si. $O$ belo transitório, por conseguinte, se

${ }^{210}$ C.Baudelaire. Le peintre de la vie moderne, in O.C., II. Paris: Gallimard, Bibliothèque de la Pléiade, 1976, p. 685. 
expressa na vontade de excesso e na exigência de gasto que acabam por corromper o corpo e exibir-lhe a beleza degenerada. Não é à toa que para Bataille a beleza é um objeto que invariavelmente pede profanação, isto é, as disposições do terrível já atuam no belo pela vontade de excesso e a sensação de terror que isso desperta tem a ver com a consumação do corpo e de seu sujeito (a morte da consciência): "eu sou, você é, apenas perda num mesmo vasto movimento de despesa". ${ }^{211}$ Eis o movimento que arruína o aspecto ideal da beleza em favor da instabilidade do efêmero para o triunfo das legiões de forças terríveis.

Michel Leiris aponta no sentido da beleza a erupção de uma ferida ou fenda, fêlure. Esta fenda, tanto em Leiris quanto em Bataille, é aberta pelo erotismo. Reencontra-se, aqui, o viés pelo qual o erotismo e as representações da sexualidade se manifestam na história da literatura e da arte. Para Bataille, em princípio, a fenda é desordem, desequilíbrio, mas também, acesso a uma efusão soberana. No reino dos corpos, a exuberância declina porque está sujeita à lei do gasto e da consumação de si, que interferindo no equilíbrio do belo, acelera as forças degenerativas do elemento temporal: o sentido último da beleza é sua própria agonia.

$\mathrm{Na}$ interpretação de Leiris, este elemento relativo e transitório, já assinalado por Baudelaire, sobressai com relação ao outro sentido do belo, eterno e invariável, introduzindo na beleza o fator de corrupção, que interrompe o caráter de uma "beleza abstrata e indefinível", perpetuando indefinidamente a situação da "mulher antes de seu primeiro pecado". ${ }^{212}$ Ou seja, é o erotismo (e, no extremo, a libertinagem) que corrompe a beleza ao mesmo tempo em que a transgride e completa. Para o mundo homogêneo do trabalho e da razão, as forças heterogêneas que a experiência erótica libera manifestam o mal, explicitado pelo sentido efêmero da beleza. A sexualidade é terrível porque está vinculada àquilo que a cultura designa como mal: a vontade de excesso dos corpos. Daí o sentido da nudez em Bataille, que abre para a sujeira do erotismo e, no limite, para a morte.

À beleza é inevitável tanto a degradação quanto o pecado e o horror mais abjeto. Essa associação se deve ao fato de que, segundo Foucault, nossa sexualidade, depois

\footnotetext{
${ }^{211}$ V. A. Arnaud e G.Exoffon-Lafarge, Bataille, op., cit., p. 78.

${ }^{212}$ M. Leiris, Miroir de la tauromachie. Paris: Fata Morgana, 1981, p. 36.
} 
de Sade e da morte de Deus, foi absorvida no universo da linguagem. ${ }^{213}$ Assim, por mais que o elemento ideal e invariável da beleza produza seu efeito nos corpos belos e jovens, o elemento relativo e efêmero encarrega-se de deteriorar este corpo sob o signo do excesso e sob a lei do gasto; de acordo com esta concepção, retira-se "o belo de sua estagnação glacial". 214

Em Bataille, o sentido de beleza do corpo como objeto oscilante, indica, tanto uma mudança na forma do objeto (do corpo viçoso e belo ao deteriorado e velho), quanto o acontecimento subjetivo da experiência erótica, que "responde à interioridade do desejo". 215

A questão da beleza em Bataille está essencialmente ligada ao corpo em excesso e se restringe à experiência do erotismo. Com isso, a beleza passa a ser considerada do ponto de vista da economia do desejo: "um homem e uma mulher são geralmente julgados bonitos na medida em que suas formas se afastam da animalidade". ${ }^{216}$ Este afastamento, implícito na recusa do referente "odioso" da animalidade, tem relação com o desejo e está na base do erotismo. Bataille se refere ao sistema capilar, "cujo sentido é singular na espécie humana", pois, embora oculto (ou por isto mesmo), revela a "verdade animal" da mulher.

\begin{abstract}
A imagem da mulher desejável, dada em primeiro lugar, seria insípida - ela não provocaria o desejo - se ela não anunciasse, ou não revelasse, ao mesmo tempo, um aspecto animal secreto, mais densamente sugestivo. A beleza da mulher desejável anuncia suas partes pudendas: justamente suas partes peludas, suas partes animais. O instinto inscreveu em nós o desejo por estas partes. Mas além do instinto sexual, o desejo erótico responde a outros componentes. A beleza negadora da animalidade, que desperta o desejo, culmina na exasperação do desejo, à exaltação das partes animais? ${ }^{17}$
\end{abstract}

Tem-se de volta, com esta formulação, o mesmo tipo de tensão entre elementos díspares e contrastantes, agenciados na relação entre o limite e o excesso, mas, desta vez, os naipes são de fatura distinta: o elemento terrível se anuncia agora, não mais sob aspecto ontológico, ligado à temporalidade, como no poema de Rilke, mas como

\footnotetext{
${ }^{213} \mathrm{M}$. Foucault. Prefácio à transgressão, in Estética: Literatura e Pintura, Música e Cinema. Col. Ditos \& Escritos III. Rio de Janeiro: Forense Universitária, 2001, p. 45.

${ }^{214}$ M. Leiris, op., cit., p. 36.

${ }^{215}$ O.C., X, L'érotisme, p. 33.

${ }^{216}$ Id., ibid., p. 142.

217 Id., ibid., pp. 142-143.
} 
um dado antropológico considerável: a animalidade. Esta "busca da beleza", como refere Bataille, tem na raiz um desejo pelo que está recalcado. Exceder este limite, profanar este objeto (quanto mais belo for o corpo, maior será a profanação, diz Bataille), é realizar o ponto mais alto da experiência erótica: estabelecer entre os corpos uma relação de continuidade, pois o erotismo é a experiência deste resgate. Ora, "o limite só é dado para ser excedido" [...] e "o horror experimentado significa o excesso ao qual devemos chegar, ao qual, se não fosse o horror preliminar, não teríamos podido chegar". ${ }^{218}$ Surge, assim, o topos da sujeira, a ser lido na esteira semântica da relação entre sexualidade e morte.

Se a beleza, cuja perfeição rejeita a animalidade, é passionalmente desejada, é que nela a posse introduziu a sujeira animal. Ela é desejada para ser sujada. Não por ela mesma, mas pela alegria experimentada na certeza de profanála. ${ }^{219}$

"A sujeira é a essência da beleza", afirma Bataille. Leia-se esta frase na chave do excesso. Quem participa no belo, degenera, se corrompe, explicitando-se no corpo que envelhece, na flor que murcha, no objeto que deteriora, considerados a partir da economia do gasto. Em suma, o horror é o sentido de superação que o excesso confere à beleza, sendo esta a razão pela qual ele é intolerável. O intolerável, no entanto, é o que se deseja, pois abre a ferida no sujeito e explicita, no trânsito da beleza ao horror, o sentido do ser como falta jamais preenchida. O fim da beleza anuncia a morte do ser:

\author{
Je te trouve dans l'étoile \\ je te trouve dans la mort \\ tu es le gel de ma bouche \\ tu as l'odeur d'une morte \\ tes seins s'ouvrent comme la bière \\ et me rient de l'au-delà \\ tes deux longues cuisses délirent \\ ton ventre est nu comme un râle \\ tu es belle comme la peur \\ tu es folle comme une morte. ${ }^{220}$
}

\footnotetext{
${ }^{218}$ Id., ibid., p. 143.

${ }^{219}$ Id., ibid., p. 143

${ }^{220}$ "Eu te encontro na estrela / eu te encontro na morte / és o gelo da minha boca / tens o odor de uma morta / teus seus se abrem como a cova / e riem para mim do além / tuas longas coxas deliram / teu ventre é nu como um ralo / és bela como o medo / és louca como uma morta". O.C., III, L'archangélique, p. 85.
} 
Aqui, a vontade de excesso liga o erotismo à morte e a linguagem comunica esta fusão. A beleza só faz sentido como afirmação das relações entre o corpo excessivo e o corpo excedido, isto é, em decomposição. A figura do cadáver perpassa o poema como um reflexo obsedante projetando-se nos pronomes "je", "tu”, "ma", "tes", "ton”, e se entrelaçando aos termos próprios da linguagem erótica: "seios", "boca", "coxas", "ventre nu". O cadáver erotizado é o puro reconhecimento de soberania do princípio de despesa, a prova contundente de que, na intensidade e na continuidade, o erotismo faz valer suas disposições vitais para exprimir "o vasto movimento da despesa", do supremo luxo da inoperância e de seu triunfo, enquanto vontade de excesso, sobre a razão homogênea e seu mundo ideal, incapazes de deter tal movimento. Figurando a vida como inseparável da morte, o cadáver erotizado é algo difícil de suportar.

Em seu artigo "A linguagem das flores", Bataille comenta que a verdade destes seres vegetais é ocultada por aquilo que exibem de mais superficial, como o perfume e as cores das pétalas, resultando disso toda a simbologia ligada ao amor, à vida. No entanto, "a flor trai rapidamente as exigências humanas, quando sua maravilhosa corola apodrece e a flor se revela frágil e fétida como o corpo humano" ${ }^{221}$ Por analogia, a pele é a fronteira que separa o exterior harmonioso e belo do interior repugnante, constituído por uma maçaroca de nervos, vísceras, vasos linfáticos, órgãos, sangue, secreções. O interior do corpo é tido como horrível e repelente. Aqui, defronta-se de novo com a fronteira que aparta o belo ideal do abjeto terrível. $O$ abjeto é a imagem mesma do terrível que se forma a partir do intolerável, a tensão criada entre o fim da beleza e o começo do terror. Assim, o abjeto surge por debaixo da pele como a podridão da flor. A pele nos defende da sujeita, isto é, da evidência da morte, nos resguardando do horror da parte maldita, a qual não se deve ver, sendo a imagem de nossa própria ruína. Para nós, a pele funciona, não apenas como aparelho protetor do corpo, mas como limite entre o belo suportável e o intolerável horror. Rasgá-la, revirá-la, decompô-la, nos põe em contato com o que há de terrível em nós mesmos. É verdade que o corpo só se expõe desse modo em casos de cirurgia, acidente, ou de óbito na mesa de autópsia. Mas é dentro do útero materno que a vida começa: o rebento, eliminado pelo organismo

${ }^{221}$ O.C., I, "Le langage des fleurs", p. 176. 
da mãe, vem do mesmo lugar imundo (e por isso mesmo sagrado) dos fluxos internos como as urinas e os excrementos.

Em Bataille, a experiência da profanação é, simultaneamente, um movimento de contestação e de resgate: contestação "do que impede a ruína" e sua demanda de despesa, resgate da parte extirpada e "maldita", revelando que, no extremo, não há fronteira, nem dentro, nem fora: em seu fluxo e consumação de forças, a vida é soberana, a morte, "impostura". 222

${ }^{222}$ L'expérience intérieure", op., cit., p. 83. 


\section{BIBLIOGRAFIA:}

\section{Obras de Georges Bataille:}

BATAILLE, Georges Oeuvres complètes. Paris: Gallimard, 1970-1988, t.I a XII. O Erotismo. Claúdia Fares (trad). São Paulo: Arx, 2004.

Paulo:Ática, 1992.

A experiência interior. Celso Libânio Coutinho e outros (trad) São A parte maldita. Julio Castañon Guimarães (trad). Rio de Janeiro: Imago, 1975.

História do olho. Eliane Robert Moraes (trad). São Paulo: Cosac \&Naif, 2003.

\section{Obras sobre Georges Bataille:}

SURYA, Michel. Georges Bataille, la mort à l'oeuvre. Paris, Gallimard, 1992.

ARNAUD, Alain e EXCOFFON-LAFARGE, Gisèle. Bataille, Écrivains de toujours. Paris, Seuil, 1978.

FOURNY, Jean-François. Introduction à la lecture de Georges Bataille. Frankfurt am Main: Peter Lang, 1988.

MORAES, Eliane Robert. O corpo impossível. São Paulo: lluminuras, 2002.

SASSO, Robert. Georges Bataille: le système du non-savoir. Paris: Les édition de minuit (col. "Arguments"), 1978

SOLLERS, Philippe, (org).Bataille. Paris: U.G.E, col. 10/18, 1973.

"Le toit", L'écriture et l'expérience des limites. Paris: Seuil, 1968.

HOLLIER, Denis, (org). Georges Bataille après tout. Paris: Belin, 1995.

HABERMAS, Jürgen.O discurso filosófico da modernidade. São Paulo: Martins Fontes, 2002. 
MARMONDE, Francis, (org). Bataille- Leiris: L'intenable assentiment au monde. Paris: Belin, 1999.

BAUDRILLARD, Jean. "La mort chez Bataille", L'échange symbolique et la mort. Paris: Gallimard, 1976.

\section{Outras obras:}

KOJÈVE, Alexandre. Introduction à la lecture de Hegel. Paris: Gallimard, 1947.

KARL, Marx. O capital: crítica da economia política: livro I. Rio de Janeiro: Civilização Brasileira, 2008.

SMITH, Adam. An Inquiry into the Nature and Causes of the Wealth of Nations. London: William Benton, Publisher, 1952. Investigação sobre a natureza e as causas da riqueza das nações. São Paulo: Abril Cultural, col. Os pensadores, vol. XXVIII, 1974.

PLOTINO. Ennéades, I e V. Paris: Société d'édition, "Les belles lettres", trad. Émile Bréhier, 1960.

Tratado das Enéadas. São Paulo: Polar Editorial, 2002.

AGAMBEN, Giorgio. A linguagem e a morte. Belo Horizonte: Editora UFMG, 2006.

UFMG, 2010.

Homo Sacer: o poder soberano e a vida nua I. Belo Horizonte: Editora

NIETZSCHE, Friedrich. Die Geburt der Tragödie aus dem Geiste der Musik, Gesammelte Werke. Bindlach: Gondrom, 2005

O nascimento da tragédia. São Paulo: Companhia das Letras, 1992.

A gaia ciência. São Paulo: Companhia das Letras, 2007.

Genealogia da moral. São Paulo: Companhia das Letras, 2005.

KOSSOVITCH, Leon. Signos e poderes em Nietzsche. Rio de Janeiro: Azougue Editorial, 2004. 
DELEUZE, Gilles. Diferença e repetição. Rio de Janeiro: Graal, 2006. e GUATTARI, Felix. O anti-édipo. Rio de Janeiro: Imago, 1976.

HEGEL, Friedrich. Fenomenologia do espírito. Petrópolis: Vozes, 2002.

BERGSON, Henri. O riso. São Paulo: Martins Fontes, 2002.

KLOSSOWSKI, Pierre. Nietzsche e o círculo vicioso. São Paulo: Pazulin, 2003.

DERRIDA, Jacques. "De l'économie restreinte à l'economie générale", L'écriture et la différence. Paris: Seuil, 1967.

FOUCAULT, Michel. "Prefácio à transgressão", Estética: Literatura e Pintura, Música e Cinema, col. Ditos \& Escritos III. Rio de Janeiro: Forense Universitária, 2001.

MAUSS, Marcel. "Ensaio sobre a dádiva", Sociologia e Antropologia. São Paulo: Cosac \& Naif, 2003. e HUBERT, Henri. Sobre o sacrifício. São Paulo: Cosac \& Naif, 2005.

CAILLOIS, Roger. L'homme et le sacré. Paris: Gallimard, 1950.

LEIRIS, Michel. Miroir de la tauromachie. Paris: Fata Morgana, 1981.

LYOTARD, Jean-François. Économie Libidinale. Paris: Minuit, 1974.

WEBER, Marx. A ética protestante e o espírito do capitalismo. São Paulo: Cia das

Letras, 2008.

J.HUIZINGA, Homo ludens. São Paulo: Perspectiva, 2008

PAZ, Octavio. El arco y la lira. México: Fundo de Cultura Económica, 1972.

H.H.Read, Geologia: uma introdução à história da terra. Mira-Sintra: Publicações Europa-América, 1976

SADE. La nouvelle Justine I e II. Paris: Union Générale D'éditions, 1978. Les crimes de l'amour. Paris: Jean-Jacques Pauvert, 1961.

RIMBAUD, Arthur. Oeuvres. Paris: Garnier, 1960.

TODOROV. Tzvetan. Os gêneros do discurso. São Paulo: Martins Fontes, 1980. 
RILKE. Rainer Maria. Dora Ferreira da Silva (trad). Elegias de Duíno. São Paulo: Globo, 2001.

BAUDELAIRE, Charles. Les fleurs du mal, Oeuvres complètes I e II. Paris: Gallimard, 1975. 